\title{
Effects Of Fe2O3 and Al203 Nanoparticle-Diesel Fuel Blends on the Combustion, Performance and Emission Characteristics of a Diesel Engine
}

Mohammad Nouri

Islamic Azad University Najafabad Branch

Amir Homayoon Meghdadi Isfahani ( $\nabla$ amir_meghdadi@pmc.iaun.ac.ir)

Islamic Azad University Najafabad Branch https://orcid.org/0000-0003-4811-2928

Alireza Shirneshan

Islamic Azad University Najafabad Branch

\section{Research Article}

Keywords: Hybrid nanoparticle fuel blend, Diesel, Performance, Emission, Engine

Posted Date: April 27th, 2021

DOI: https://doi.org/10.21203/rs.3.rs-412132/v1

License: (c) (i) This work is licensed under a Creative Commons Attribution 4.0 International License.

Read Full License 


\title{
Effects of $\mathrm{Fe}_{2} \mathrm{O}_{3}$ and $\mathrm{Al}_{2} \mathrm{O}_{3}$ nanoparticle-diesel fuel blends on the
}

\section{combustion, performance and emission characteristics of a diesel engine}

\author{
Mohammad Nouri ${ }^{1}$, Amir Homayoon Meghdadi Isfahani ${ }^{1,2 *}$, Alireza Shirneshan ${ }^{1,2}$ \\ ${ }^{1}$ Department of Mechanical Engineering, Najafabad Branch, Islamic Azad University, Najafabad, \\ Iran \\ ${ }^{2}$ Aerospace and Energy Conversion Research Center, Najafabad Branch, Islamic Azad University, \\ Najafabad, Iran \\ Corresponding Auther*: amir_meghdadi@pmc.iaun.ac.ir
}

\begin{abstract}
This research investigates the effects of the addition of $\mathrm{Fe}_{2} \mathrm{O}_{3}$ and $\mathrm{Al}_{2} \mathrm{O}_{3}$ nanoparticles $(30$, 60, and 90 ppm) and $\mathrm{Fe}_{2} \mathrm{O}_{3}-\mathrm{Al}_{2} \mathrm{O}_{3}$ hybrid nanoparticles to pure diesel fuel on the combustion, performance and emission characteristics of a diesel engine. The results indicated that fuel blends improved the combustion (in-cylinder pressure and heat release rate), performance (power, fuel consumption, and thermal and exergy efficiency), and emission characteristics of the engine. The results showed that the peak combustion pressure increased by $4 \%$ and the heat release rate was improved by $15 \%$ in comparison with pure diesel with the addition of the nanoparticles. Moreover, the rate of pressure rise increased by $18 \%$ compared to pure diesel with nanoparticle additives. Based on the results, the effects of $\mathrm{Fe}_{2} \mathrm{O}_{3}$ fuel blends on brake power, BTE, and $\mathrm{CO}$ emission were more than $\mathrm{Al}_{2} \mathrm{O}_{3}$ fuel blends, such that it increased power and thermal efficiency by 7.40 and $14 \%$, respectively, and reduced $\mathrm{CO}$ emissions by $21.2 \%$; moreover, the blends with $\mathrm{Al}_{2} \mathrm{O}_{3}$ nanoparticle additives in comparison with $\mathrm{Fe}_{2} \mathrm{O}_{3}$ nanoparticle blends showed a better performance in reducing BSFC (9\%), $\mathrm{NO}_{x}(23.9 \%)$, and $\mathrm{SO}_{2}(23.4 \%)$ emissions. Overall, the $\mathrm{Fe}_{2} \mathrm{O}_{3}-\mathrm{Al}_{2} \mathrm{O}_{3}$ hybrid fuel blend is the best alternative if the performance and emission characteristics of the engine are both considered.
\end{abstract}

Keywords: Hybrid nanoparticle fuel blend, Diesel, Performance, Emission, Engine

\begin{tabular}{|c|c|c|c|}
\hline \multicolumn{4}{|l|}{ Abbreviations } \\
\hline $\mathrm{D}+\mathrm{Al} 30$ & Diesel+ $30 \mathrm{ppm} \mathrm{Al}_{2} \mathrm{O}_{3}$ nanoparticles & D & Diesel \\
\hline $\mathrm{D}+\mathrm{Al} 60$ & Diesel+ $60 \mathrm{ppm} \mathrm{Al}_{2} \mathrm{O}_{3}$ nanoparticles & $\mathrm{CO}$ & Carbon monoxide \\
\hline $\mathrm{D}+\mathrm{Al} 90$ & Diesel+ $90 \mathrm{ppm} \mathrm{Al}_{2} \mathrm{O}_{3}$ nanoparticles & NOx & Nitrogen oxides \\
\hline $\mathrm{D}+\mathrm{Fe} 30$ & Diesel+30 ppm $\mathrm{Fe}_{2} \mathrm{O}_{3}$ nanoparticles & $\mathrm{SO}_{2}$ & Sulfur dioxides \\
\hline $\mathrm{D}+\mathrm{Fe} 60$ & Diesel+60 ppm $\mathrm{Fe}_{2} \mathrm{O}_{3}$ nanoparticles & BTE & Brake thermal efficiency \\
\hline $\mathrm{D}+\mathrm{Fe} 90$ & Diesel+90 ppm $\mathrm{Fe}_{2} \mathrm{O}_{3}$ nanoparticles & BSFC & Brake specific fuel consumption \\
\hline $\mathrm{D}+\mathrm{Fe} 30+\mathrm{Al} 30$ & $\begin{array}{l}\text { Diesel+30ppm } \mathrm{Fe}_{2} \mathrm{O}_{3} \text { and } 30 \text { ppm } \mathrm{Al}_{2} \mathrm{O}_{3} \\
\text { nanoparticles }\end{array}$ & HRR & heat release rate \\
\hline
\end{tabular}




\section{Introduction}

The high demands for fossil fuels, environmental problems, and global warming have necessitated the use of alternative and renewable fuels (Amiri and Shirneshan 2020). Today, using nanoparticle such as NO (Srinidhi 2017), $\mathrm{ZrO}_{2}$ (Venu and Madhavan 2016b) and $\mathrm{TiO}_{2}$ (Venu et al. 2019) additives in diesel engine fuels is proposed for improving performance, combustion, and emission properties of the diesel engines.

Heterogeneous combustion kinetics and ignition acceleration reaction, which result in high energy density, are some of the results of using fuel blends in diesel engines (Chen et al. 2018). Heterogeneous combustion occurs to complete forming the final products by the heat and is convectively transferred to the unburnt reactants. Moreover, the higher ratio of surface to volume helps to more rapid the oxidation during combustion and the higher the combustion enthalpy (Sivakumar et al. 2018). Other advantages of nanoparticles are high evaporation rate, good atomization, acceptable flame sustainability, and appropriate air-fuel mixing, all of which significantly reduce ID (Sivakumar et al. 2018). The good atomization of the fuel leads to an earlier start of the combustion process. Metal nanoparticle additives improve the combustion and performance efficiency of the conventional fuel; however, these additives have some downsides, the most important of which is that the exhaust gas of the engine fuelled with metal nanoparticles may contain solid metal oxides as the residual particulate matter which imposes a significant health risk, hence the necessity of incorporating a particulate filter on the engine using nanoparticle additives. Among other drawbacks, mention can be made of the risk of agglomeration, costly supply, and difficulty related to uniform dispersion (Basu and Miglani 2016). So it is needed to incorporate a particulate filter on the engine using nanoparticle additives. Chance of agglomeration, costly supply, and difficulty in uniform dispersion are other disadvantages. Because nanoparticle additives should lead to optimal emission and performance parameters of the engines, the extra costs pertaining to nanoparticle supply, mixture stability and dispersion process should be kept at a minimum. There are specific approaches to preventing nanoparticles from coagulating or settling down. The fundamental mechanism that prevents nanoparticle agglomeration and affects their stability is using surfactants, surface modification, steric repulsion, and electrostatic repulsion( $\mathrm{Yu}$ and Xie 2012).

There is some research on the impact of fuel blends on the performance, emission, and combustion properties of diesel engines. For instance, there have been reports regarding the effects of $\mathrm{TiO}_{2}$ fuel blends on improving BTE and decreasing brake specific fuel consumption, $\mathrm{HC}$ and $\mathrm{CO}$ emissions (D'Silva et al. 2015); the effect of $\mathrm{TiO}_{2}$ nano additives and exhaust gas recovery on increasing the performance and minimizing the exhaust emissions of biodiesel fuels (Venu et al. 2019); the impact of $\mathrm{MgO}$ and $\mathrm{SiO}_{2}$ nano additives on reducing $\mathrm{NOx}$ and $\mathrm{CO}$ emissions and improving engine performance (Ozgur et al. 2015); the effect of $\mathrm{CeO}_{2}$ nanoparticles in Lemongrass oil emulsion fuel on enhancing the engine performance and improving $\mathrm{HC}$ and $\mathrm{CO}$ emissions (Annamalai et al. 2016), and the influence of cerium oxide-calophyllum biodiesel in the engine with five-hole nozzle (NH5) injectors on decreasing $\mathrm{HC}$ and NOx emission and improving BSFC. In an experimental research, Soukht Saraee et al. (2017) observed that NOx and HC were reduced with using $\mathrm{CeO}_{2}$ nanoparticles-diesel fuel blends, while carbon monoxide emissions were slightly 
increased. Besides, there was a reduction in BSFC, and no significant changes were reported in terms of brake power compared to pure diesel fuel.

In another experimental study (Örs et al. 2018), the influence of a mixture of biodiesel, titanium dioxide, n-butanol, and diesel was investigated on the emission and performance parameters of a $\mathrm{CI}$ engine. An increase was observed in the combustion pressure and HRR using $\mathrm{TiO}_{2}$, improving brake torque and power by up to $10 \%$. Moreover, BSFC was reduced by around $30 \%$ following the addition of $\mathrm{TiO}_{2}$ nanoparticles. $\mathrm{HC}$, and $\mathrm{CO}$ emissions were reduced while $\mathrm{NO}$ and $\mathrm{CO}_{2}$ emissions increased. The authors further reported that waste frying oil biodiesel, $\mathrm{TiO}_{2}$, and normal butanol additive were capable of enhancing the combustion, emission, and performance characteristics.

Also, Najafi (2018) investigated that adding carbon nanotubes and Ag nanoparticle blend to biodiesel and diesel increased the peak of combustion pressure and the peak of PRR in comparison with pure diesel fuel. Also, the HRR of the diffusion combustion phase was higher due to the higher oxygen content of the blended fuels that have improved the diffusion combustion phase and decreased the combustion duration. Moreover, ID was reduced by around $9 \%$ utilizing biodiesel +120 ppm carbon nanotubes additive compared to conventional fuel.

Among the nano additives, $\mathrm{Al}_{2} \mathrm{O}_{3}$ and $\mathrm{Fe}_{2} \mathrm{O}_{3}$ nanoparticles have attracted scientific attention. Iron nanoparticles (ferrocene) have been dissolved in the fuel as a combustion catalyst in previous studies (Braun et al. 2006).

In another work, Ozgur et al. (2015) showed that blending nanoparticle additives such as $\mathrm{Al}_{2} \mathrm{O}_{3}$, $\mathrm{MgO}, \mathrm{TiO}_{2}, \mathrm{ZnO}, \mathrm{SiO}_{2}$, and $\mathrm{Fe}_{2} \mathrm{O}_{3}$ with conventional diesel fuel reduced NOx emissions.

Ooi et al. (2016) used graphite oxide, aluminium oxide, and cerium oxide nanoparticles to investigate the combustion parameters of a CI engine. A notable improvement in combustion efficiency and reducing the harmful emissions were further observed using nanoparticles in the diesel engine.

Chen et al. (2018) conducted the some experimental tests on a diesel engine to investigate the effect of nanoparticles (alumina, carbon nanotubes, $\mathrm{SiO}_{2}$ ) blended with diesel fuel. According to the results, the brake specific fuel consumption was dropped by up to $20 \%$ and BTE was increased by $19 \%$. Moreover, $\mathrm{SiO}_{2}$ blends were more effective than alumina blends due to improving combustion pressure, BSFC, BTE, and CO emissions. However, carbon nanotube blended with diesel enhanced NOx emissions.

The effect of $\mathrm{Al}_{2} \mathrm{O}_{3}$ nanoparticle addition to the blend of biodiesel, diesel, and ethanol on various injection strategies was studied by Venu and Madhavan (2016a) who showed that $\mathrm{Al}_{2} \mathrm{O}_{3}$ addition at advanced timing augmented the peak pressure, $\mathrm{HC}, \mathrm{CO}$, and $\mathrm{NOx}$ and reduced $\mathrm{CO}_{2}$ and the ignition delay ID. However, $\mathrm{Al}_{2} \mathrm{O}_{3}$ addition with retarded timing resulted in lower cylinder pressure and reduced $\mathrm{HC}, \mathrm{CO}, \mathrm{NOx}$, and smoke opacity. The brake specific fuel consumption and combustion duration were further observed to be reduced during retarded timing by use of $\mathrm{Al}_{2} \mathrm{O}_{3}$. Finally, the results of this research revealed that alumina ameliorated the combustion, performance, and emission parameters of the engine.

Mandilas et al. (2016) evaluated the combustion of 25-85 $\mathrm{nm}$ iron nanoparticles as a replacement fuel for internal engines under idealized conditions (combustion in customized shock tube), 
engine-like conditions (combustion in a constant-volume vessel) and real engine conditions. They reported that the combustion of Fe nanoparticles could be done in CI engine with a slight modification; however, there exist certain technological challenges associated with ignition and scavenging that reduce the chances of good combustion.

In another experimental study (Sadhik Basha and Anand 2012) the performance and emission of a $\mathrm{CI}$ engine fuelled with water-alumina-diesel emulsion were studied. Based on the results, alumina fuel blends significantly ameliorated the engine performance and reduced the emission of pollutants.

Gumus et al. (2016) showed that adding $50 \mathrm{ppm} \mathrm{Al}_{2} \mathrm{O}_{3}$ or $\mathrm{CuO}$ nanoparticles to neat diesel caused an increase in the brake power and torque and a reduction in $\mathrm{HC}, \mathrm{CO}, \mathrm{NO}_{\mathrm{x}}$ emissions. The nanoparticles concentration was assumed constant $(50 \mathrm{ppm})$ and the hybridization effect was not presented.

Elahi M.Soudagar et al. (Soudagar et al. 2018) in a review paper reported that there is further scope for enhancement in fuel properties and to overcome the drawbacks by the addition of nanoparticles to bio fuels. The results demonstrated an improvement in the thermo-physical properties, enhancement in the heat transfer rate, and stabilization of the fuel mixtures. Also, there was an increase in the engine performance parameters and a reduction in exhaust emissions depending on the dosage of nanoparticle additives.

In the El-Seesy et al. (2018) work, the effect of alumina nanoparticles $\left(\mathrm{Al}_{2} \mathrm{O}_{3}\right)$ into Jojoba biodiesel-diesel blend on the performance and exhaust emissions of a diesel engine was investigated. The results revealed that using of $\mathrm{Al}_{2} \mathrm{O}_{3}$ additives can improve all engine performance characteristics; and the best emission characteristics were obtained at the dose level of $20 \mathrm{mg} / \mathrm{l}$, where NOx, CO, HC, and smoke opacity were significantly reduced. According to the comparisons of engine performance and emissions, the recommended concentration of $\mathrm{Al}_{2} \mathrm{O}_{3}$ in Jojoba biodiesel-diesel blend was concluded to be $30 \mathrm{mg} / \mathrm{l}$, which gave remarkable enhancement in all engine parameters.

The engine performances and exhaust emissions of aluminium oxide $\left(\mathrm{Al}_{2} \mathrm{O}_{3}\right)$ and silicon dioxide $\left(\mathrm{SiO}_{2}\right)$ nanoparticles blended in palm oil methyl ester were evaluated in Adzmi et al. (2019). Various engine loads at a constant engine speed of $1800 \mathrm{rpm}$ were applied during engine tests. The results showed that the highest maximum pressure of nanoparticle fuel increases by $16.3 \%$ compared to POME test fuel. Besides, the engine peak torque and engine power showed a significant increase of $43 \%$ and $44 \%$, respectively. Moreover, the emissions of nanoparticles fuel indicated a large decrease in $\mathrm{NOx}$ and $\mathrm{CO}_{2}$, and a slight decrease in $\mathrm{CO}$ emission.

Based on the literature review, the utilizing of nanoparticle additives was found to improve engine power, torque and combustion parameters and reduce BSFC. Moreover, nanoparticle additives cause a reduction in hydrocarbon, carbon monoxide, and smoke emissions. However, there are negative effects for using oxygenated nanoparticle additives in increasing the NOx emission because of providing oxygen molecules in a chain reaction. Literature reviews also showed that there are so far no research focused on the using mixture of $\mathrm{Fe}_{2} \mathrm{O}_{3}$ and $\mathrm{Al}_{2} \mathrm{O}_{3}$ nanoparticles (Hybrid fuel blend) in diesel engine; therefore, the objective of this study is to present a comprehensive study which investigates and compares the effects of different concentrations of $\mathrm{Fe}_{2} \mathrm{O}_{3}$ and $\mathrm{Al}_{2} \mathrm{O}_{3}$ nanoparticles and their mixture $\left(\mathrm{Fe}_{2} \mathrm{O}_{3}-\mathrm{Al}_{2} \mathrm{O}_{3}\right.$ Hybrid fuel blend) in a diesel engine. To this end, $\mathrm{Al}_{2} \mathrm{O}_{3}$ and $\mathrm{Fe}_{2} \mathrm{O}_{3}$ and $\mathrm{Fe}_{2} \mathrm{O}_{3}-\mathrm{Al}_{2} \mathrm{O}_{3}$ Hybrid nano particles with 30, 60 and 90 
ppm concentrations was blended in diesel fuel and their effect on the combustion (in-cylinder pressure and heat released rate), performance (torque, brake power, BSFC, BTE, and exergy) and emission $\left(\mathrm{CO}, \mathrm{NOx}\right.$, and $\mathrm{SO}_{2}$ ) parameters of a $\mathrm{CI}$ (diesel) engine under various rpms and loads is presented.

\section{Materials and Methods}

In this study, aluminum oxide $\left(\mathrm{Al}_{2} \mathrm{O}_{3}\right)$ and iron (III) oxide $\left(\mathrm{Fe}_{2} \mathrm{O}_{3}\right)$ nanoparticles were supplied from Tamadkala Shop. Three concentrations of 30, 60, and $90 \mathrm{ppm}$ of each nanoparticle were used to evaluate the impact of nanoparticles on the performance and gaseous emissions of a CI engine.

\subsection{Preparation of different fuel blends}

The most common method for stabilizing nanoparticle additives in fuels is the use of surfactants (Chen et al. 2018), which results in the proper distribution of nanoparticles in the fuel, hence better stability(Ghadimi et al. 2011; Yu and Xie 2012). In the current study, SPAN 80 surfactant was used to create the relative stability of the fuel $(0.045 \mathrm{mgr}$ SPAN80 for $30 \mathrm{ppm}$ nanoparticles). In order to mix nanoparticles with the fuel, an ultrasound bath with a frequency of $40 \mathrm{kHz}$, a power of $240 \mathrm{~W}$, and a temperature of $50^{\circ} \mathrm{C}$ was used for 40 minutes. A slight amount of nanoparticle agglomeration was observed after 2 days. For rehomogenizing, the fuel blend was positioned under ultrasonic waves prior to use in the engine. The engine was fuelled with different fuel blends during the tests: pure diesel, D+Fe30, D+Fe60, D+Fe90, D+ AL30, D+ AL 60, D+ AL 90 and $\mathrm{D}+\mathrm{Fe} 30+\mathrm{AL} 30$. Properties of the fuel mixtures and the images of the prepared fuel blends were presented in Appendix 1. It is to be noted that the hybrid fuel blend is black because the colour of $\mathrm{Fe}_{2} \mathrm{O}_{3}$ nanoparticles is dominant.

\subsection{Test set-up and instruments}

Figure 1 and Table 1 show the test set up and engine specifications, respectively. 


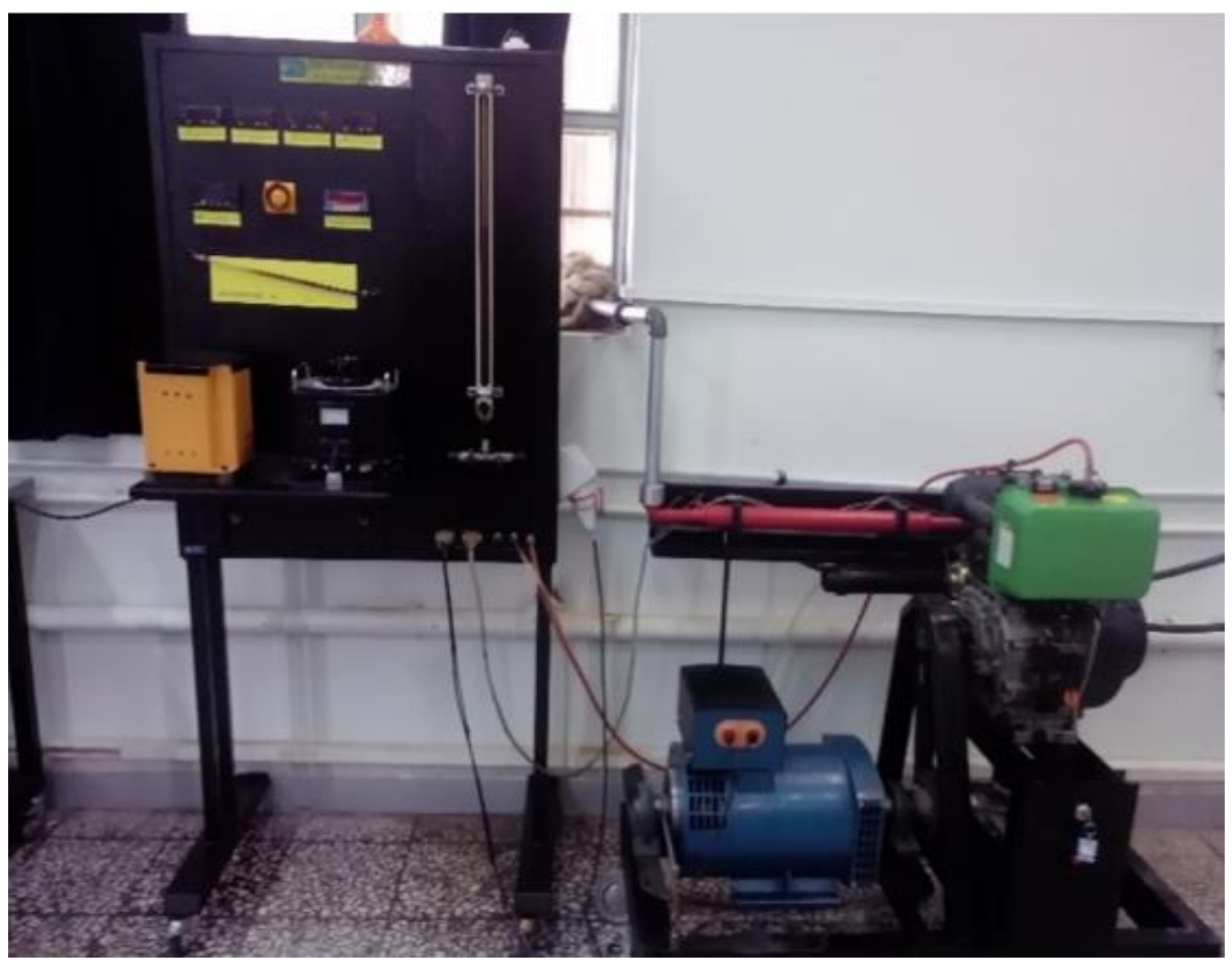

Figure 1: The engine test set-up

Table 1: Diesel engine specifications

\begin{tabular}{c|c}
\hline Engine Model & $186 \mathrm{~F}$ \\
\hline Manufacturer & $\begin{array}{c}\text { Zhejiang Wenxin Mechanical \& Electrical Co. } \\
\text { Ltd, China }\end{array}$ \\
\hline Type & Air-cooled, Single-cylinder, Four-stroke \\
\hline Bore & $86 \mathrm{~mm}$ \\
\hline Stroke & $70 \mathrm{~mm}$ \\
\hline Rated power & $5.7 \mathrm{~kW}$ at $3000 \mathrm{rpm}$ \\
\hline Compression ratio & 19 \\
\hline Maximum torque speed & $1800 \mathrm{rpm}$
\end{tabular}

So as to measure the pollutant emissions of the engine, including carbon monoxide (CO), nitrous oxides $\left(\mathrm{NO}_{\mathrm{x}}\right)$, and sulfur dioxides $\left(\mathrm{SO}_{2}\right)$, Testo350 gas analyzer was used. The accuracy of the measured parameters is shown in Table 2. Engine tests were performed at various rpms and full engine load to determine brake power, torque, and BSFC; the tests were further carried out at 25, 50,75 , and $100 \%$ engine loads (and rated speeds of the engine to measure pollutant emissions. The 3-time repetition was applied for the experiments of each fuel blend and the average of measurements was also reported. The pressure sensor (Kistler) was utilized to measure the combustion pressure (Table 3). A crankshaft angle sensor was further employed to measure the crankshaft position and determine the in-cylinder pressure against the crank angle. Moreover, the 
net HRR (heat release rate) was determined by Eq. (1) based on the first law of thermodynamics (Li et al. 2015; Rakopoulos et al. 2010):

$\frac{d Q}{d \theta}=\frac{1}{\gamma-1}\left[\gamma P \frac{d V}{d \theta}+V \frac{d P}{d \theta}\right]$

The uncertainties of the experimental parameters are affected by different error sources, namely, the random fluctuation of employed instruments, the calibration of the test bed, the observation accuracy, and the methodology of the experiments (Singh and Verma 2019). For directly measured parameters, the measurement uncertainties are defined by the accuracies of the experimental instruments. For computed parameters, the measurement uncertainties are determined based on the principle of the root-mean-square method and the measurement accuracies of the measured parameters (Li et al. 2015; Rahman et al. 2013):

$e_{R}=\left[\left(\frac{\partial f}{\partial X_{1}} e_{1}\right)^{2}+\left(\frac{\partial f}{\partial X_{2}} e_{2}\right)^{2}+\cdots+\left(\frac{\partial f}{\partial X_{n}} e_{n}\right)^{2}\right]^{\frac{1}{2}}$

Where $e_{R}$ is the measurement uncertainty of the computed parameter, $f$ is the given function of the computed parameter, $\mathrm{e}_{1}, \mathrm{e}_{2}$, and ... are the measurement uncertainties of the related measured parameters. The uncertainties of the measured and computed parameters presented in Table 2 .

Table 2: The accuracies and uncertainties of the measurements and calculated parameters

\begin{tabular}{c|c|c}
\hline $\begin{array}{c}\text { Measured or calculated } \\
\text { parameter }\end{array}$ & Measurement range & $\begin{array}{c}\text { Accuracy of measurement/ } \\
\text { overall uncertainty in } \\
\text { computation }\end{array}$ \\
\hline Speed & $0-2500 \mathrm{rpm}$ & $\pm 1 \mathrm{rpm}$ \\
\hline $\mathrm{CO}$ & $0-10 \%$ & $\pm 0.01 \mathrm{vol} \%$ \\
\hline $\mathrm{NOx}$ & $0-5000 \mathrm{PPM}$ & $\pm 1 \mathrm{ppm}$ \\
\hline $\mathrm{SO}_{2}$ & $0-2000 \mathrm{PPM}$ & $\pm 1 \mathrm{ppm}$ \\
\hline Torque & $0-40 \mathrm{Nm}$ & $\pm 0.1 \mathrm{Nm}$ \\
\hline Brake power & - & $\pm 0.014 \mathrm{~kW}$ \\
\hline BSFC & - & $\pm 3 \mathrm{gr} / \mathrm{kWh}$ \\
\hline BTE & - & $\pm 0.1 \%$
\end{tabular}

Table 3: Technical specifications of the in-cylinder pressure sensor

\subsection{Exergy efficiency}

\begin{tabular}{c|c}
\hline Model & $6613 \mathrm{CA}$ \\
\hline Measurement range & $0-250 \mathrm{bar}$ \\
\hline Sensitivity & $10 \mathrm{mV} / \mathrm{bar}$ \\
\hline Sensitivity to acceleration & $0.001 \mathrm{bar} / \mathrm{g}$ \\
\hline Frequency range $(-3 \mathrm{~dB})$ & $0.032-20000 \mathrm{~Hz}$
\end{tabular}

Availability or maximum reversible work is the ultimate potential of a system for work production. For actual states, the output work done by the system is lower than maximum reversible work due 
to the irreversibility of the system. Therefore, the exergy efficiency can be defined as follows(Şanli and Uludamar 2019):

$\varepsilon=\frac{\dot{W}_{b}}{\dot{X}_{\text {Fuel }}}$

Where $\dot{W}_{b}$ is the engine brake power and $\dot{X}_{F u e l}$ is the fuel exergy input rate calculated by:

$\dot{X}_{\text {Fuel }}=\dot{m}_{\text {Fuel }} e_{\text {Fuel }}$

Where $\dot{m}_{F u e l}$ is the mass flow rate of the fuel and $e_{F u e l}$ is the chemical exergy of the fuel calculated by:

$\mathrm{e}_{\text {Fuel }}=\left[1.0401+0.1728 \frac{\mathrm{H}}{\mathrm{C}}+0.0432 \frac{\mathrm{O}}{\mathrm{C}}+0.2169 \frac{\mathrm{S}}{\mathrm{C}}\left(1.216901 \frac{\mathrm{H}}{\mathrm{C}}\right) \mathrm{H}_{\mathrm{u}}\right]$

$\mathrm{H}_{\mathrm{u}}$ is the LHV of the fuel and $\mathrm{H} / \mathrm{C}=0.1488, \mathrm{O} / \mathrm{C}=0$ and $\mathrm{S} / \mathrm{C}=0.07467$ are mass fractions of hydrogen, oxygen, and sulfur content to carbon content in the fuel, respectively.

\section{Results and Discussions}

The effect of using $\mathrm{Al}_{2} \mathrm{O}_{3}$ and $\mathrm{Fe}_{2} \mathrm{O}_{3}$ nano diesel fuels are presented in previous researches. However, the detailed studies on the optimization and comparison of these nano fuels are not presented so far. The present study, compares the effect of adding $\mathrm{Al}_{2} \mathrm{O}_{3}$ and $\mathrm{Fe}_{2} \mathrm{O}_{3}$ and their hybrids on performance and emissions of a diesel engine.

3.1 The properties of the nanoparticles

The properties of the nanoparticles used in this study are also presented in Table 4. Moreover, Figures 2 and 3 show the TEM and SEM analysis of the nanoparticles, confirming the size of nanoparticles presented in Table 4. These figures further show the uniformity in size and shape of nanoparticles which is a desirable feature for nanoparticles.

Table 4: nanoparticles properties used in the current study

\begin{tabular}{c|c|c|c|c}
\hline Type & Size & Purity & SSA & Colour \\
\hline $\begin{array}{c}\text { Iron (III) oxide nanoparticle } \\
\left(\mathrm{Fe}_{2} \mathrm{O}_{3}, \text { alpha) }\right.\end{array}$ & $20-40 \mathrm{~nm}$ & $+98 \%$ & $40-60 \mathrm{~m}^{2} / \mathrm{g}$ & Dark brown \\
\hline $\begin{array}{c}\text { Aluminium oxide nanoparticle } \\
\left(\mathrm{Al}_{2} \mathrm{O}_{3}, \text { gamma }\right)\end{array}$ & $20 \mathrm{~nm}$ & $+99 \%$ & $>138 \mathrm{~m}^{2} / \mathrm{g}$ & white
\end{tabular}



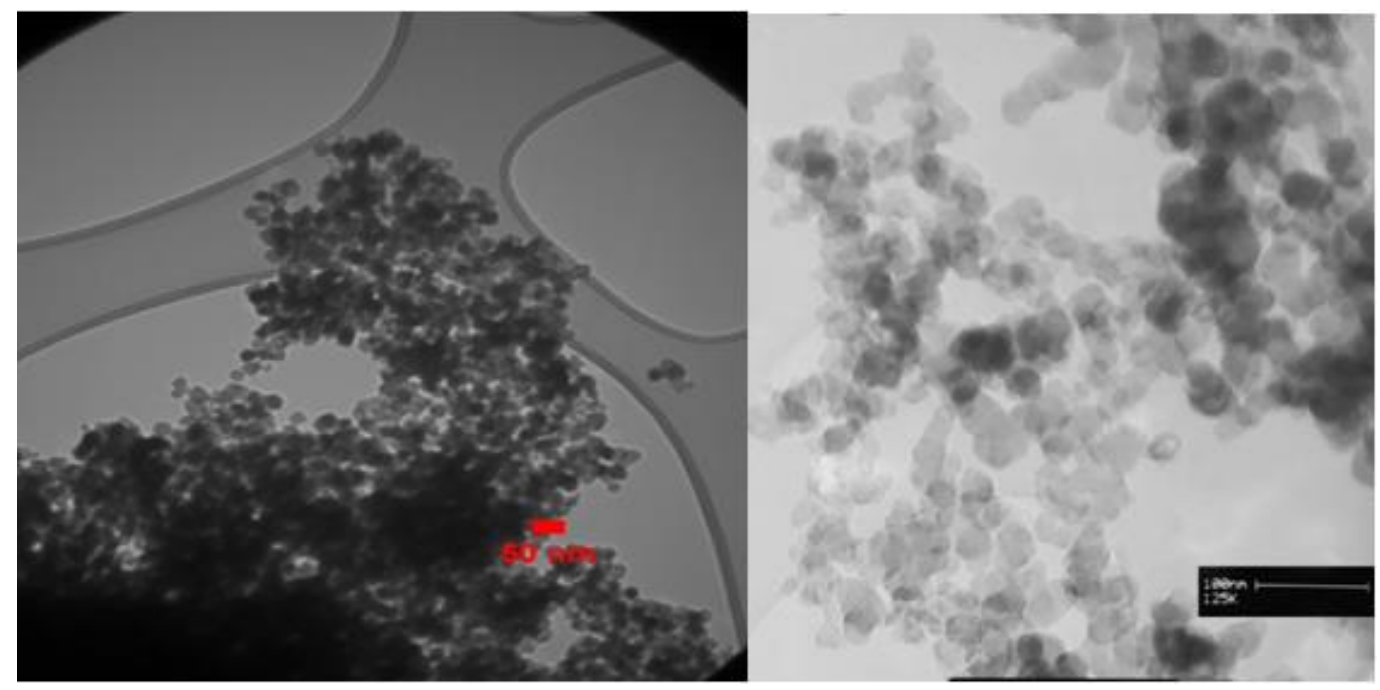

Figure 2: TEM and SEM analysis of $\mathrm{Al}_{2} \mathrm{O}_{3}$ nanoparticles

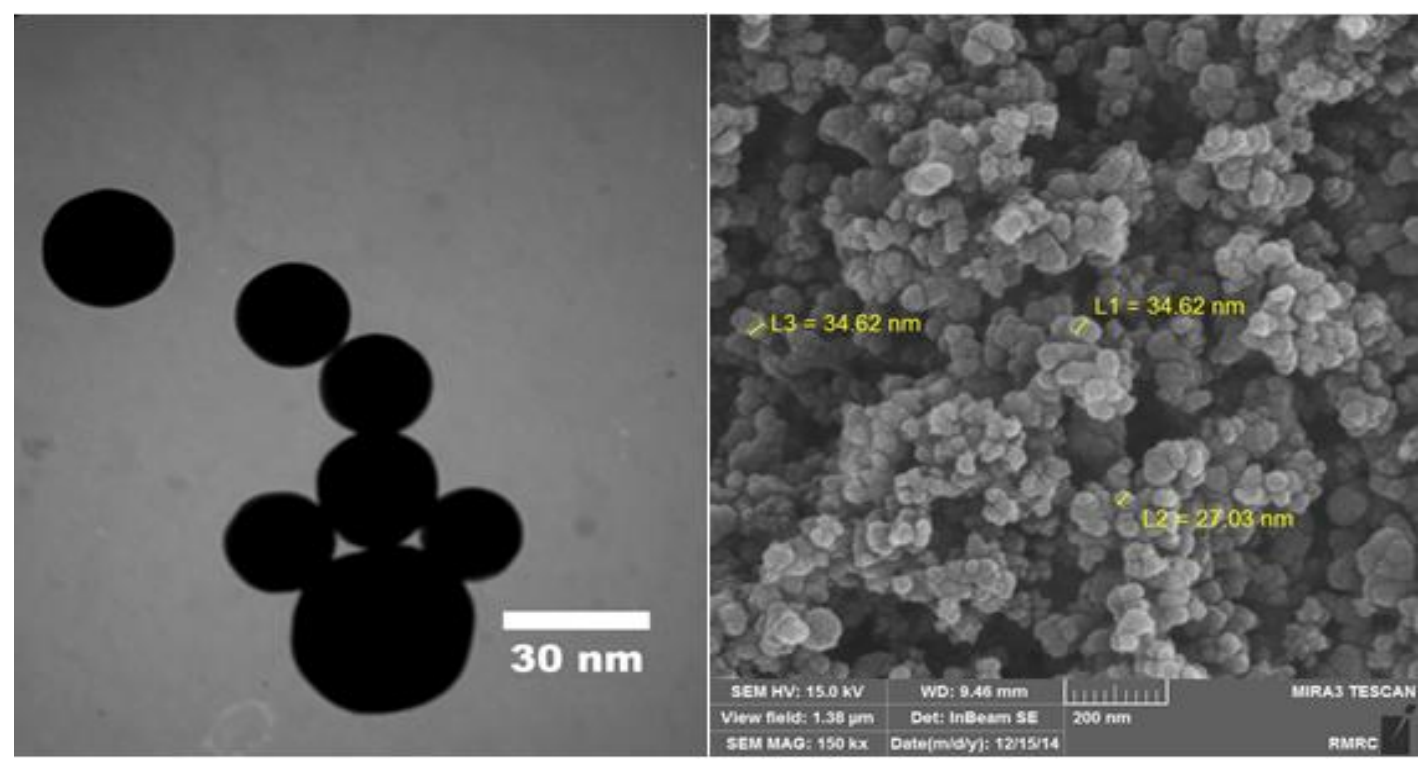

Figure 3: TEM and SEM analysis of $\mathrm{Fe}_{2} \mathrm{O}_{3}$ nanoparticles

\subsection{Effect of nanoparticle on the combustion parameters}

Figures 4 and 5 show the variation of in-cylinder (combustion) pressure versus crank angle for neat diesel and D+Fe90, D+A190, D+Fe30+A130 fuel blends at the speed of $1800 \mathrm{rpm}$ and under $50 \%$ and full engine load, respectively. The rate of pressure rise at the speed of $1800 \mathrm{rpm}$ under $50 \%$ and full engine load is further shown in Figures 6 and 7, respectively. 


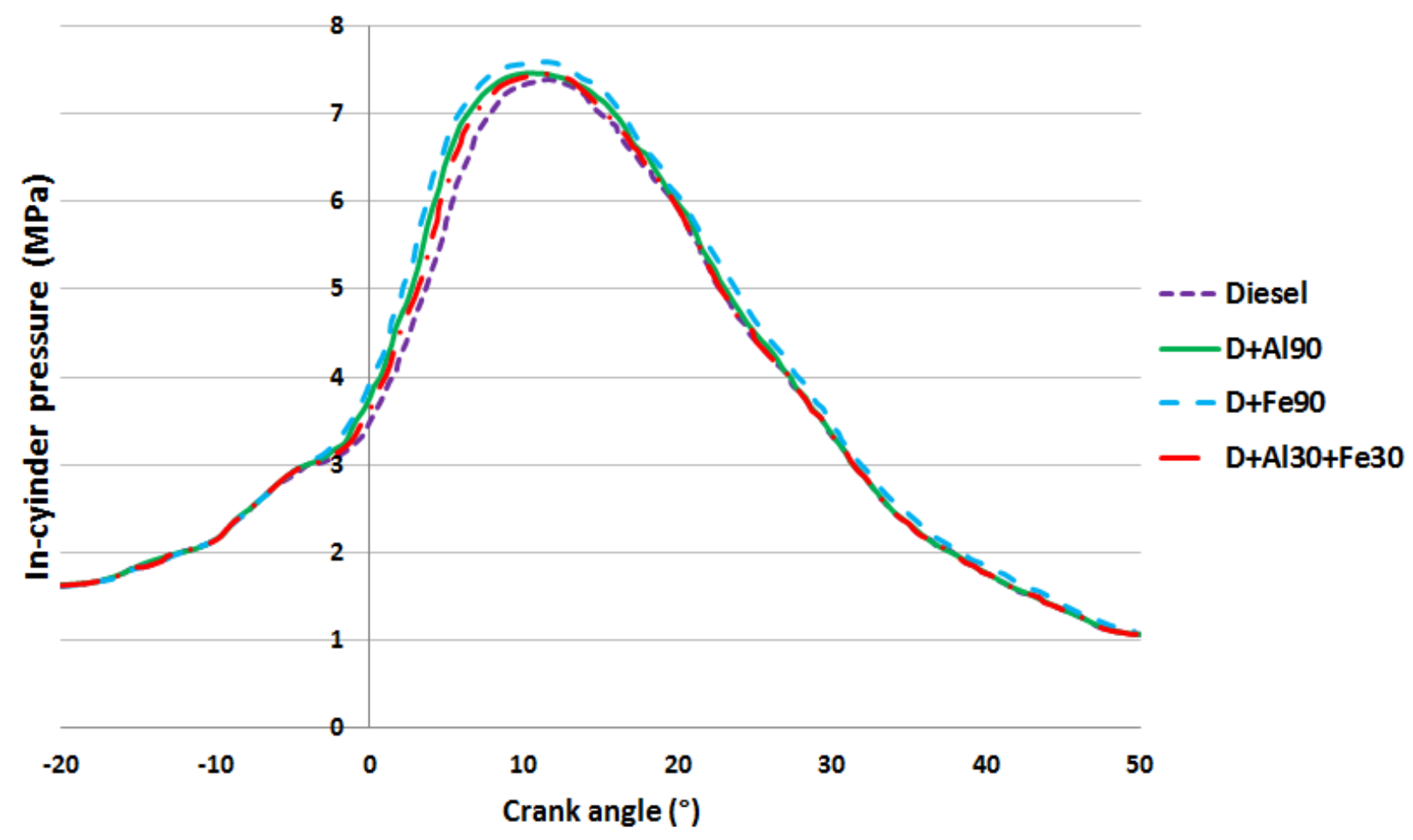

Figure 4: In-cylinder pressure variations versus crank angle at $50 \%$ engine load

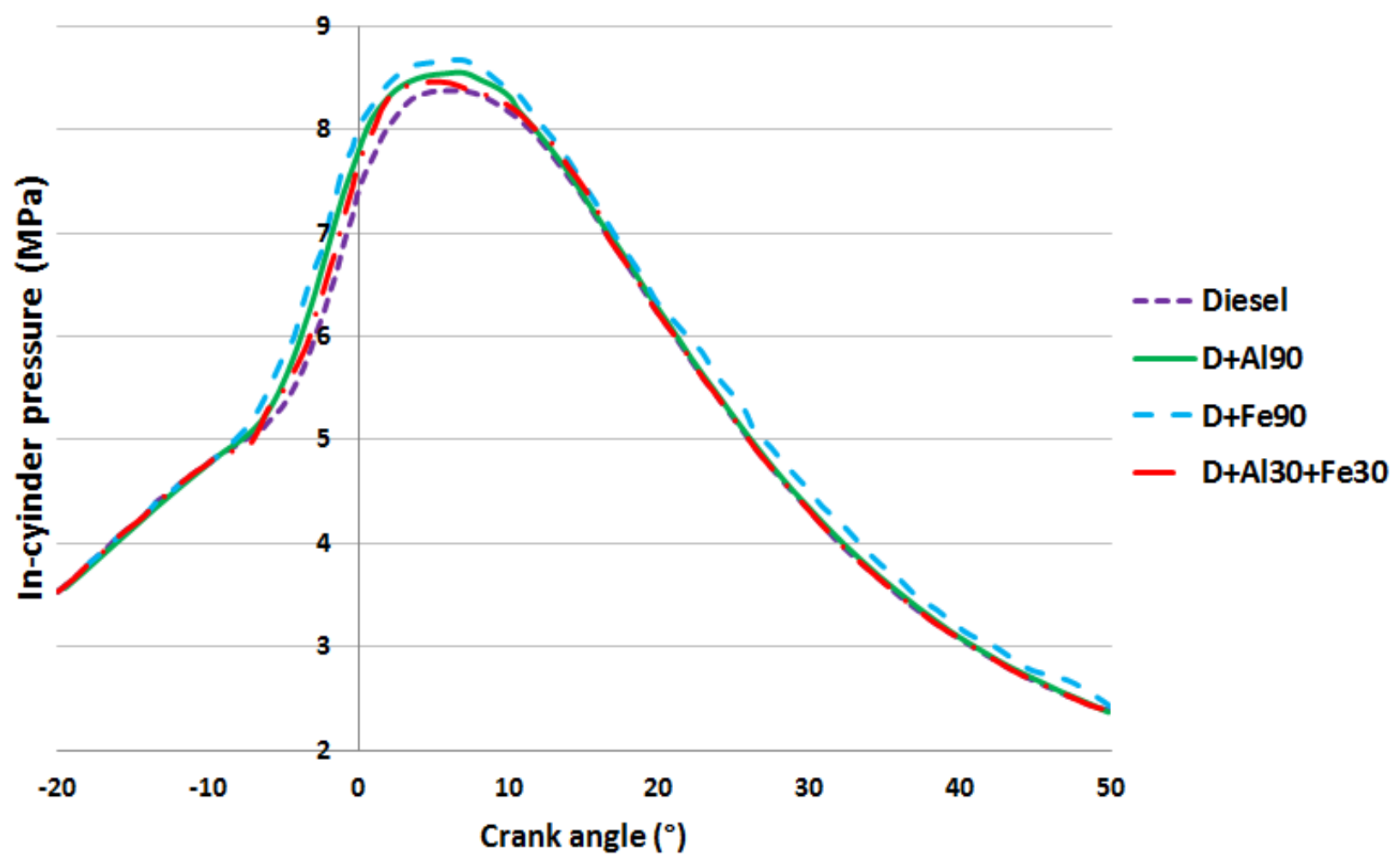

Figure 5: In-cylinder pressure variations versus crank angle at full engine load 


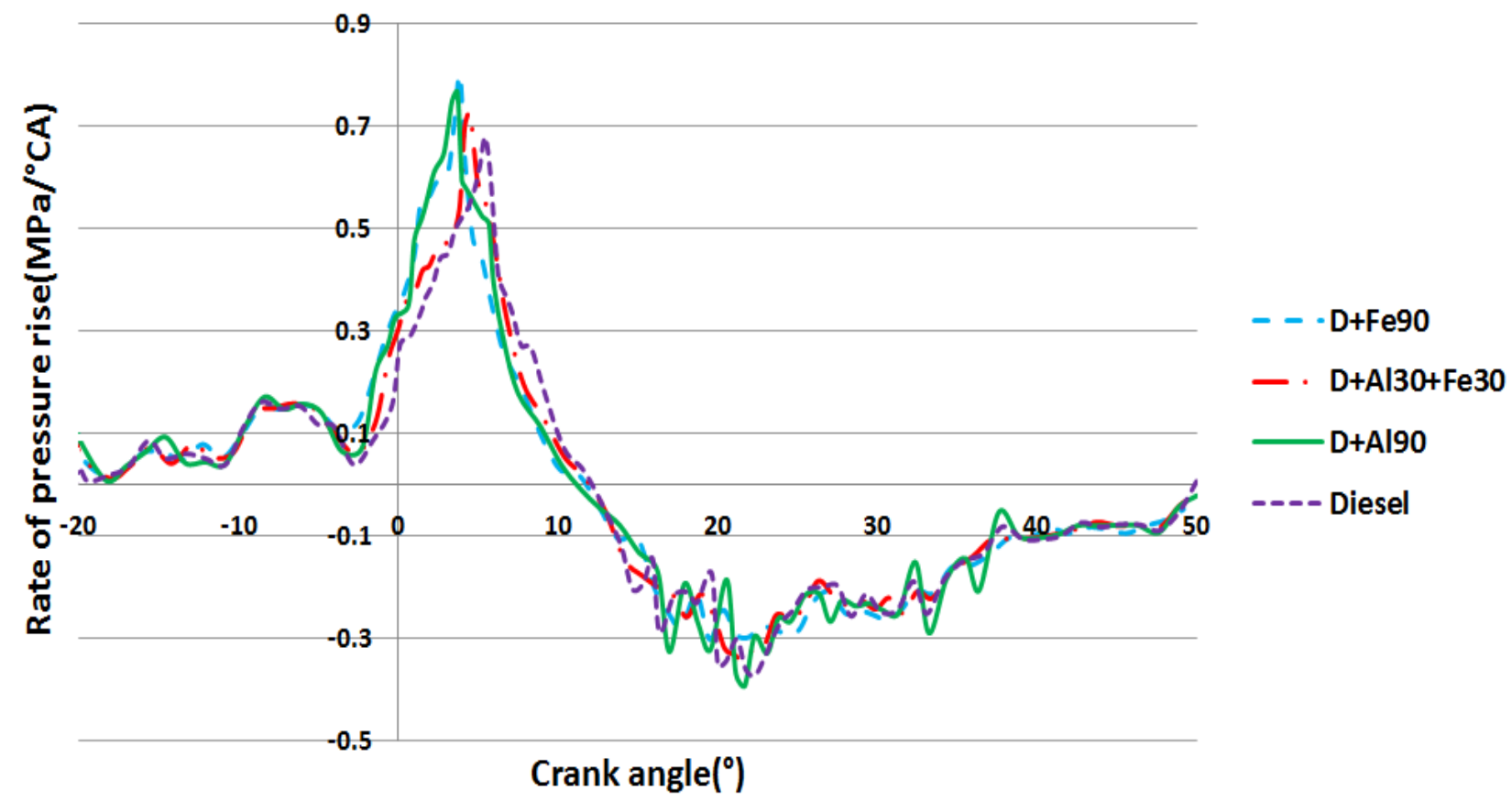

Figure 6: Variations of the rate of pressure rise against crank angle at 50\% engine load

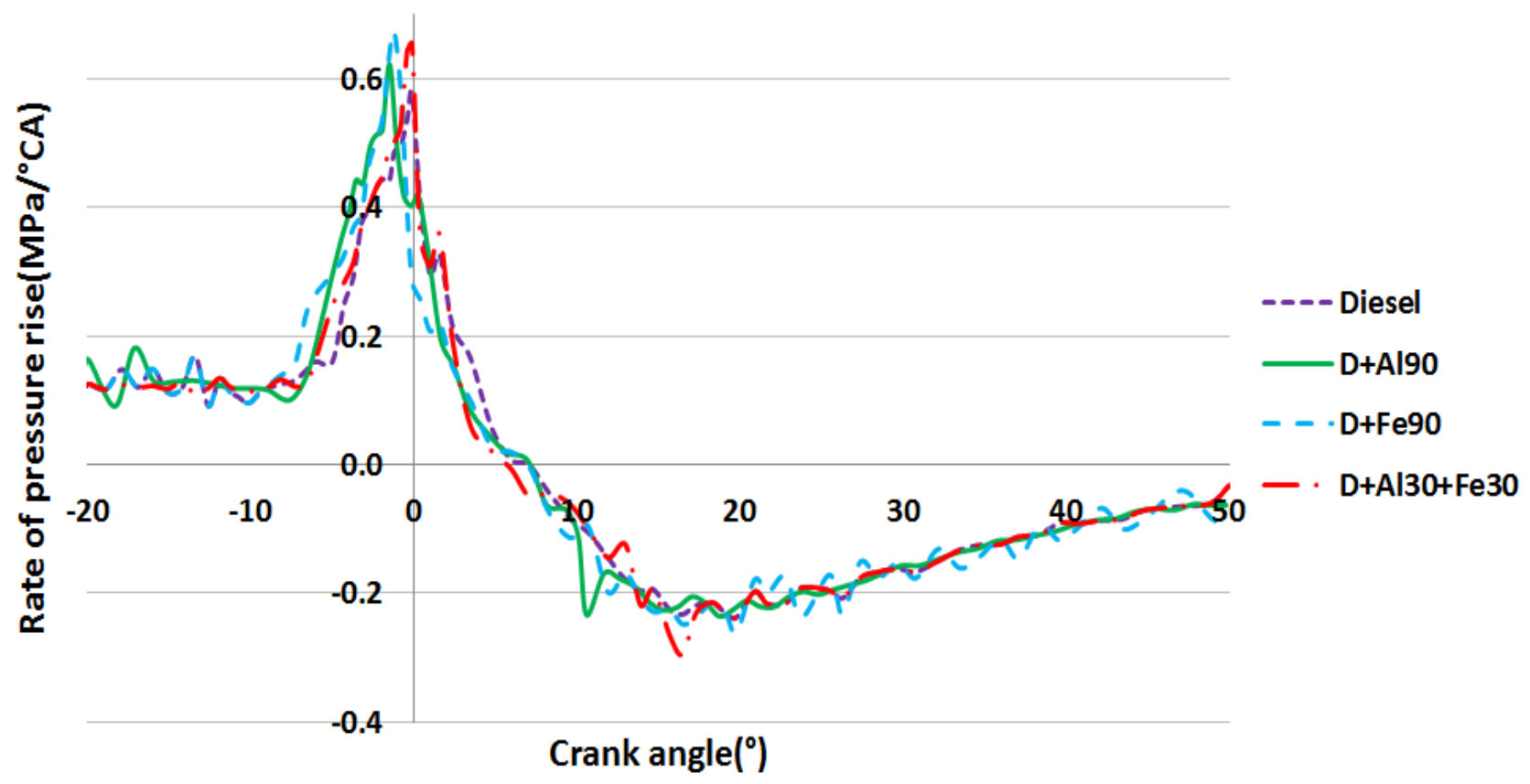

Figure 7: Variations of the rate of pressure rise against crank angle at full engine load

According to the results, the combustion conditions (especially ignition delay of diesel fuel) tend to be better with the addition of nanoparticles, and the in-cylinder pressure increased. This is due to the effect of metal oxide nanoparticles to reduce the time of fuel evaporation and increase the efficiency of the combustion (Rao and Srinivasa Rao 2015). Moreover, aluminum oxide and iron 
oxide nanoparticles have activity as an oxygen buffer that releases oxygen and promotes the complete combustion(El-Seesy et al. 2018). D+Fe90 blend was observed to have the highest incylinder pressure among other fuel blends owing to the higher LHV and lower ignition delay. The addition of nanoparticles further increased the maximum cylinder gas pressure. The combustion peak pressure developed with $\mathrm{D}+\mathrm{Fe} 30+\mathrm{A} 130, \mathrm{D}+\mathrm{A} 190$, and $\mathrm{D}+\mathrm{Fe} 90$ blends was enhanced by $0.7 \%, 1.2 \%$ and $3.1 \%$ respectively compared with neat diesel at $50 \%$ engine load. Also, the maximum cylinder gas pressure of the engine fuelled with $\mathrm{D}+\mathrm{Fe} 30+\mathrm{A} 130, \mathrm{D}+\mathrm{A} 190$, and $\mathrm{D}+\mathrm{Fe} 90$ blends increased by $1.7 \%, 2.8 \%$ and, $3.6 \%$ respectively compared with neat diesel under full engine load. According to the results, the maximum rate of pressure rise belonged to the $\mathrm{D}+\mathrm{Fe} 90$ blend occurring earlier for all blends under $100 \%$ load condition compared to $50 \%$ engine load owing to the higher combustion temperature condition which reduces the ignition delay of the fuel blends.

Figures 8 and 9 show the variation of HRR against the crank angle for neat diesel and D+Fe90, $\mathrm{D}+\mathrm{A} 190$, and $\mathrm{D}+\mathrm{Fe} 30+\mathrm{Al} 30$ fuel blends at the speed of $1800 \mathrm{rpm}$ under $50 \%$ and full engine load conditions, respectively.

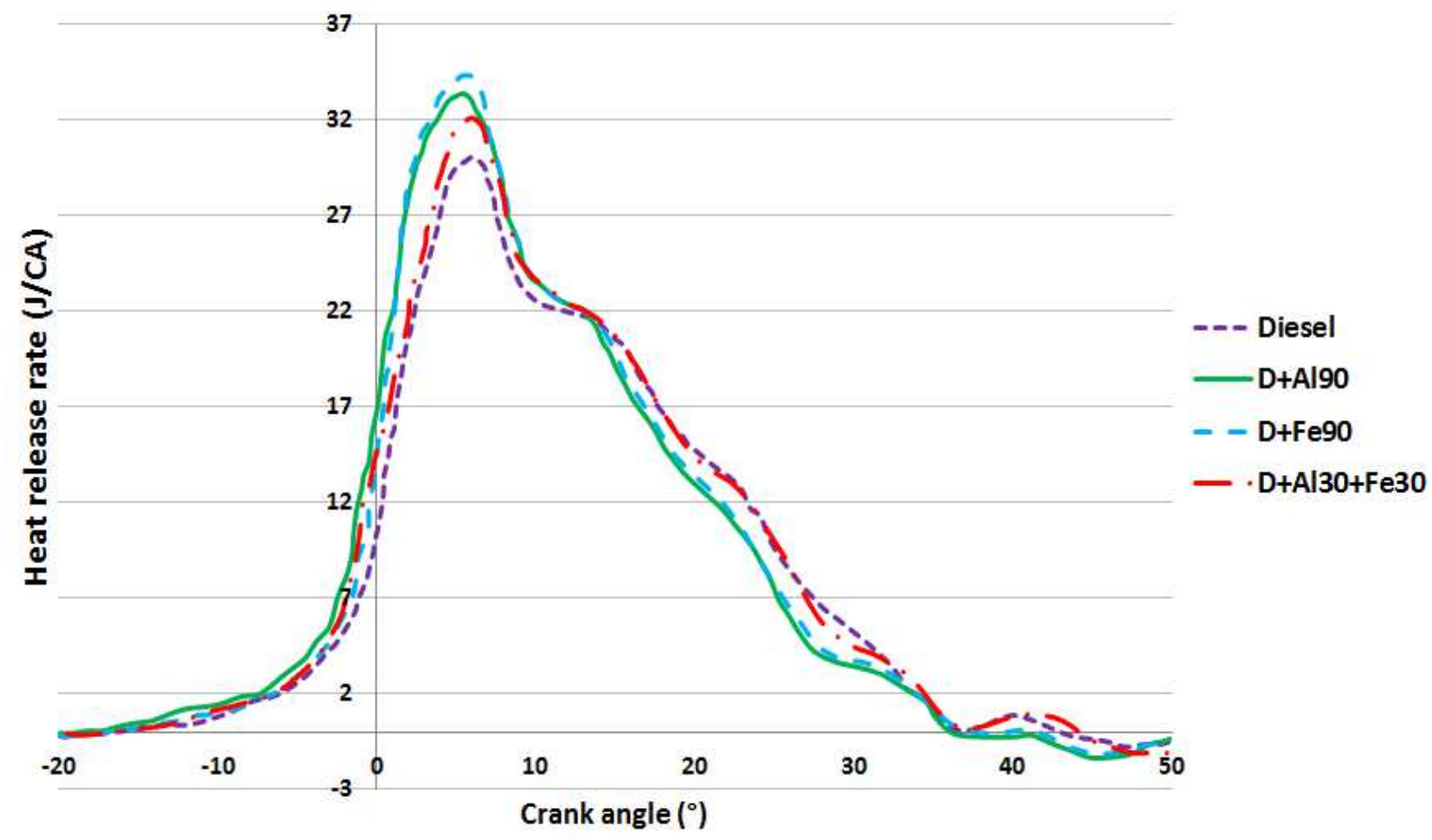

Figure 8: Variations of the HRR versus crank angle at 50\% engine load 


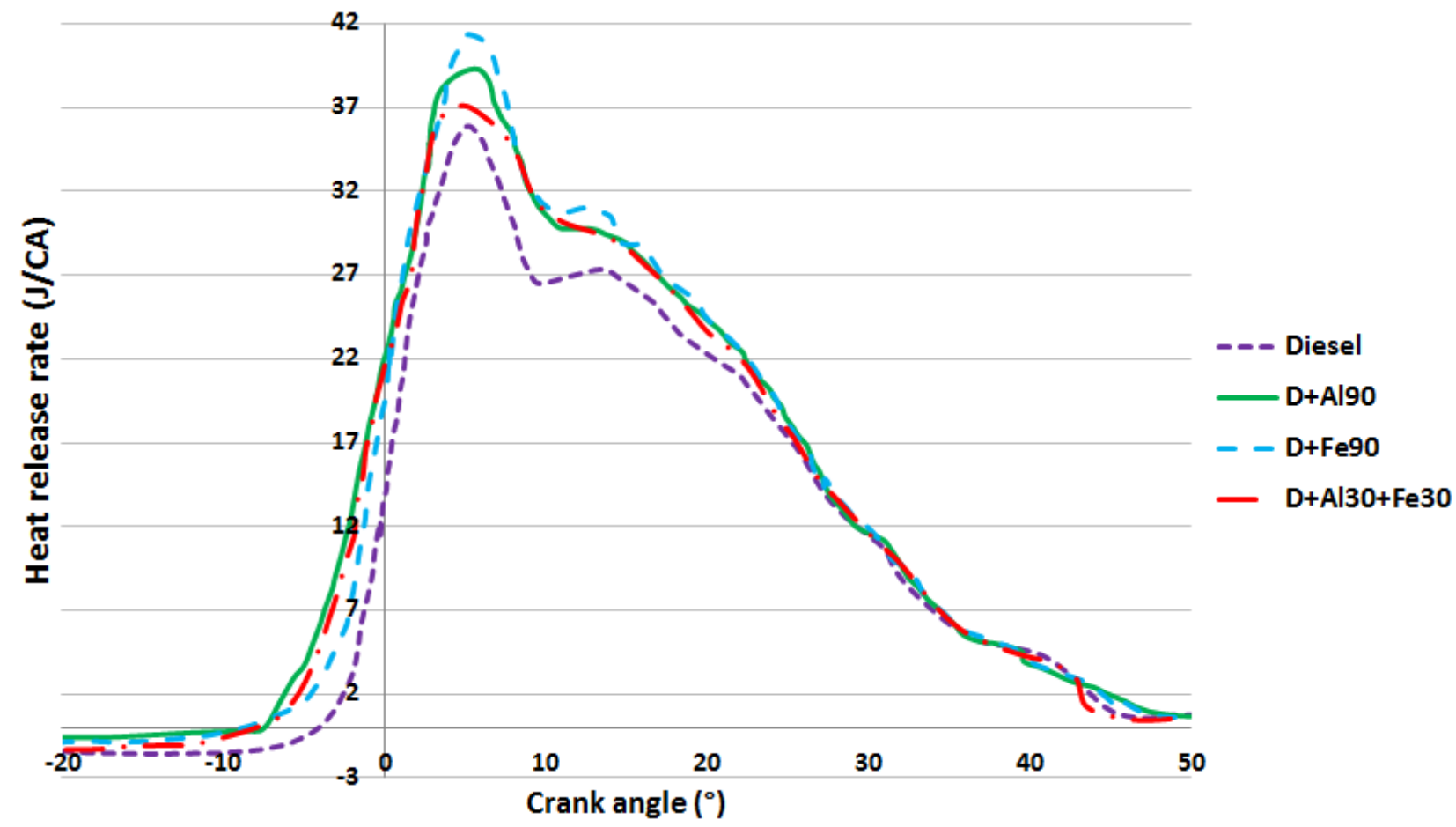

Figure 9: Variations of the HRR versus crank angle at full engine load

Based on the results, the rate of heat release was enhanced for all fuel blends compared to the diesel fuel without nanoparticle, which is in agreement with the results of Srinidhi et al. (Srinidhi et al. 2019) regarding nickel oxide nanoparticles. This is owing to the reduced ID and accelerated the process of the combustion as a result of nanoparticle addition which causes an improved combustion condition compared with neat diesel fuel (Aalam et al. 2015; Chen et al. 2018).

The maximum heat release rate of the engine was observed to increase by $3.4 \%, 9.4 \%$, and $15.2 \%$ concerning fuel blends $\mathrm{D}+\mathrm{Fe} 30+\mathrm{A} 130, \mathrm{D}+\mathrm{A} 190$ and $\mathrm{D}+\mathrm{Fe} 90$, respectively, compared to the neat diesel at $100 \%$ load. Furthermore, the maximum HRR increased by $6.8 \%, 11 \%$, and $13.9 \%$ as regards the engine fuelled with $\mathrm{D}+\mathrm{Fe} 30+\mathrm{Al} 30, \mathrm{D}+\mathrm{A} 190$, and $\mathrm{D}+\mathrm{Fe} 90$ blends, respectively, compared to the neat diesel at $50 \%$ engine load.

Because the thermal conductivity of aluminum oxide nanoparticles $(30 \mathrm{~W} / \mathrm{m} . \mathrm{K})$ is higher than that of iron oxide nanoparticles $(15 \mathrm{~W} / \mathrm{m} . \mathrm{K}), \mathrm{Al}_{2} \mathrm{O}_{3}$ nanoparticle can distribute the heat in the compression cycle (Takeda et al. 2009). Therefore, the highest heat release rate in the compression process belonged to the D+AL90 blend. On the contrary, $\mathrm{Fe}_{2} \mathrm{O}_{3}$ nanoparticles with higher LHV and lower ignition delay achieved the highest rate of heat release, and the highest HRR enhanced for all blends at higher loads owing to the better combustion in this condition(Chen et al. 2018). Compared with other studies, Najafi (2018) reported an increase of $24 \%$ and $28 \%$ in peak pressure rise rate and heat release rate respectively with using nanoparticle additives in a diesel engine. In another paper (Shaafi and Velraj 2015), the maximum HRR and peak pressure enhanced around $4 \%$ and $16 \%$ for diesel engine fuelled with nanoparticle additives.

\subsection{Effect of nanoparticle on brake torque}


For any diesel engine, torque is a function of its volumetric efficiency. Since cylinder filling is incomplete, volumetric efficiency is reduced at higher speeds, resulting in reduced engine torque (Pulkrabek 1997). Moreover, the pressure produced through combustion depends on the LHV of the fuel. Figure 10 shows the engine torque values versus rotational speed in terms of deferent nanoparticle-diesel fuel blends at full load.

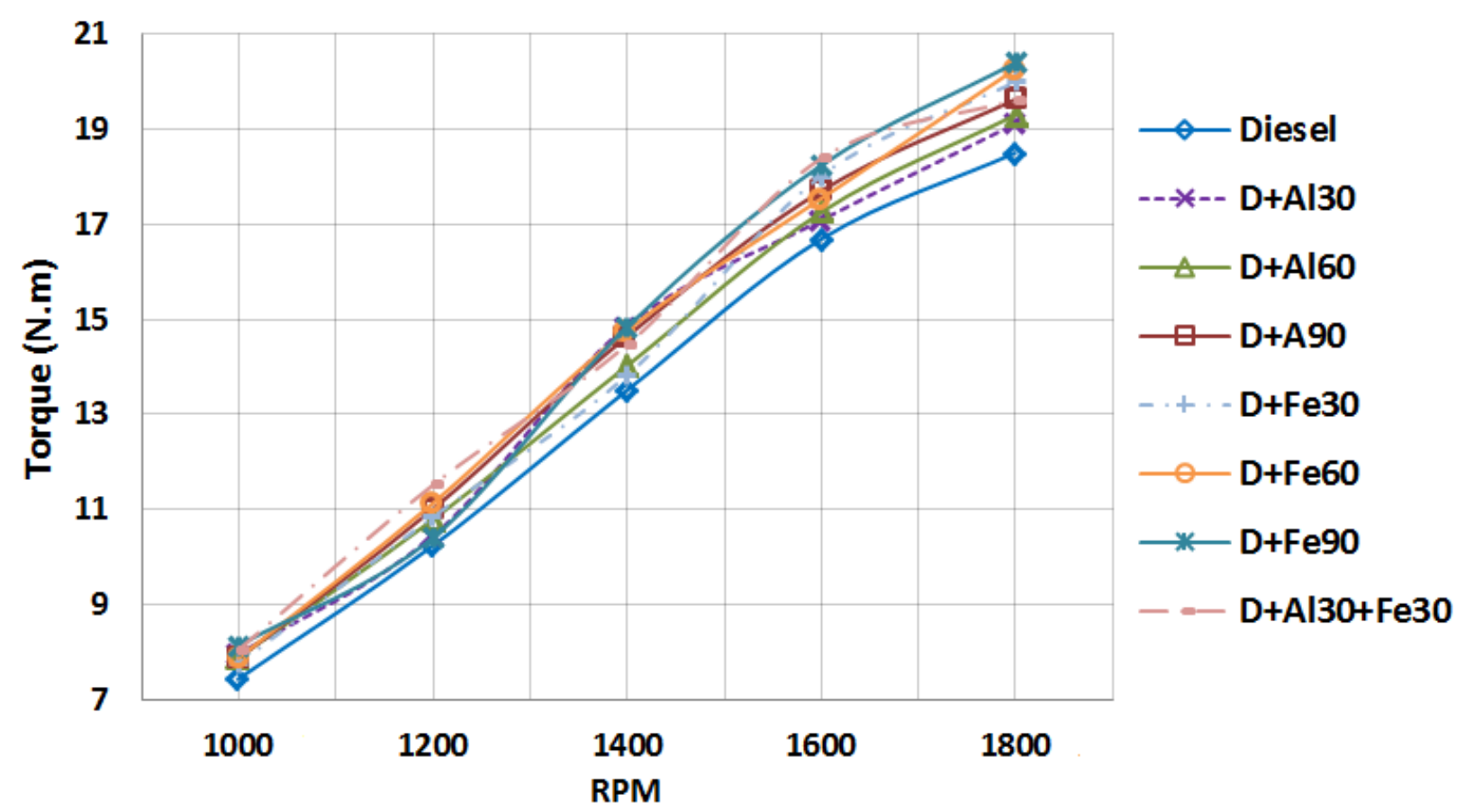

Figure 10: Brake torque values versus rotational speed for different nanoparticle-diesel fuel blends at full engine load

As observed, for all blends, with increasing the rotational speed, the brake torque increased. Based on these results, the increase in nanoparticle concentration in the mixture led to a higher engine torque which is due to the higher energy production as a result of the increased ratio of surface/volume of nanoparticles and the higher thermal conductivity of nano-metallic additives, leading to better fuel evaporation and mixing with air and efficient combustion (Attia et al. 2014). Furthermore, the addition of nanoparticles to conventional diesel fuel shortened the ID which causes complete combustion (Gumus et al. 2016). Additionally, the oxygen content in the molecular structure of nanoparticles entailed a better engine combustion efficiency and caused higher torque values (Mirzajanzadeh et al. 2015). Furthermore, the effect of $\mathrm{Fe}_{2} \mathrm{O}_{3}$ nanoparticles on brake torque was more than $\mathrm{Al}_{2} \mathrm{O}_{3}$ nanoparticles. In this regard, the maximum increase in torque $(8.6 \%)$ occurred with $\mathrm{D}+\mathrm{Fe} 90$ fuel blend, while the minimum increase $(4.7 \%)$ belonged to D+Al30 mixture compared to pure diesel fuel. Compared to the other papers, Gumus et al. (2016) concluded that the engine torque and power were increased by $1 \%$ and $3.3 \%$, respectively with the use of Aluminum oxide and copper oxide nanoparticle diesel fuel.

\subsection{Effect of nanoparticle on brake power}

Engine brake power is a function of brake torque and engine rotational speed. Therefore, the maximum engine power is directly related to engine rotational speed. Figure 11 shows the power 
values of the engine versus rotational speed concerning different nanoparticle-diesel fuel blends based on the engine tests.

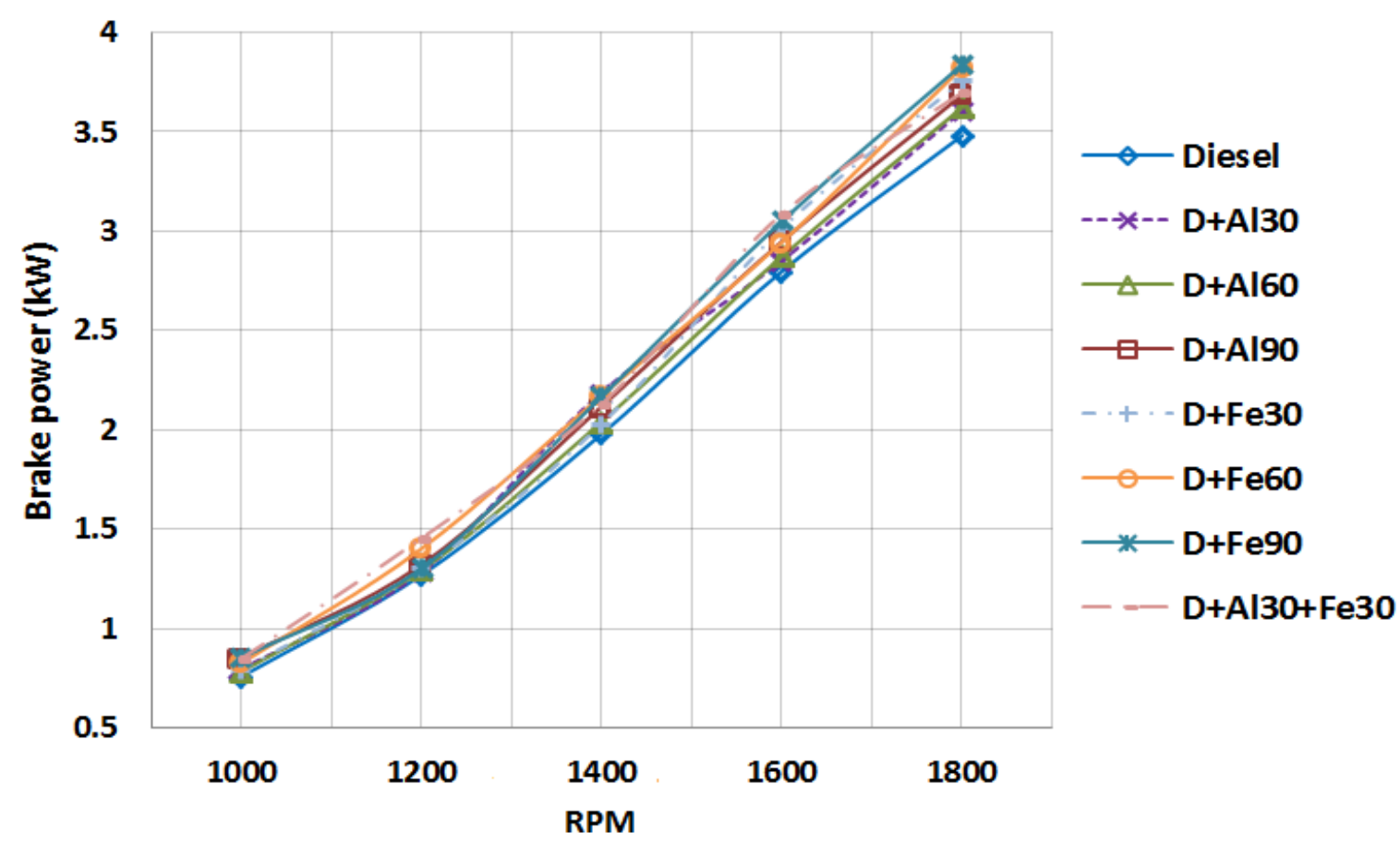

Figure 11: Brake power values versus rotational speed for different nanoparticle-diesel fuel blends at full engine load

As seen, the addition of nanoparticles in the fuel blend resulted in better combustion conditions and increased brake power, which is due to the lower ID of fuel blends included in the nanoparticles. Additionally, the oxygen buffer property of nanoparticles releasing oxygen molecules caused an increase in combustion efficiency (Gumus et al. 2016) and the higher thermal conductivity and large ratio of surface/volume enhanced cylinder pressure, resulting in a higher brake power (Sivakumar et al. 2018).

Based on the results, similar to engine brake torque, the $\mathrm{D}+\mathrm{Fe} 90$ fuel blend entailed the highest increase in brake power $(7.08 \%)$, while the D+Al30 blend led to the minimum improvement in brake power $(4.39 \%)$ compared to the pure diesel fuel. Figure 11 also shows that for all blends, the increase in engine rotational speed (1000 rpm to $1800 \mathrm{rpm}$ ) predictably resulted in higher engine power. However, some other authors reported that the brake power increased by $3.85 \%$ (Patel et al. 2017) and 3.67\% (Hosseini et al. 2017) with utilizing the nanoparticle additives.

$\mathrm{D}+\mathrm{Fe} 90$ fuel mixture generated the highest engine power at all engine rotational speeds compared to other fuel blends. The maximum brake power $(3.84 \mathrm{KW})$ also belonged to this fuel blend occurring at $1800 \mathrm{rpm}$. Furthermore, pure diesel fuel produced the minimum amount of power at all rotational speeds, hence the minimum brake power $(0.7 \mathrm{KW})$ at the rotational speed of 1000 rpm.

\subsection{Effect of nanoparticles on BSFC}


Figures 12 and 13 show the variations of brake specific fuel consumption (BSFC) versus rotational speed (rpm) for various fuel blends at $50 \%$ and full engine load, respectively.

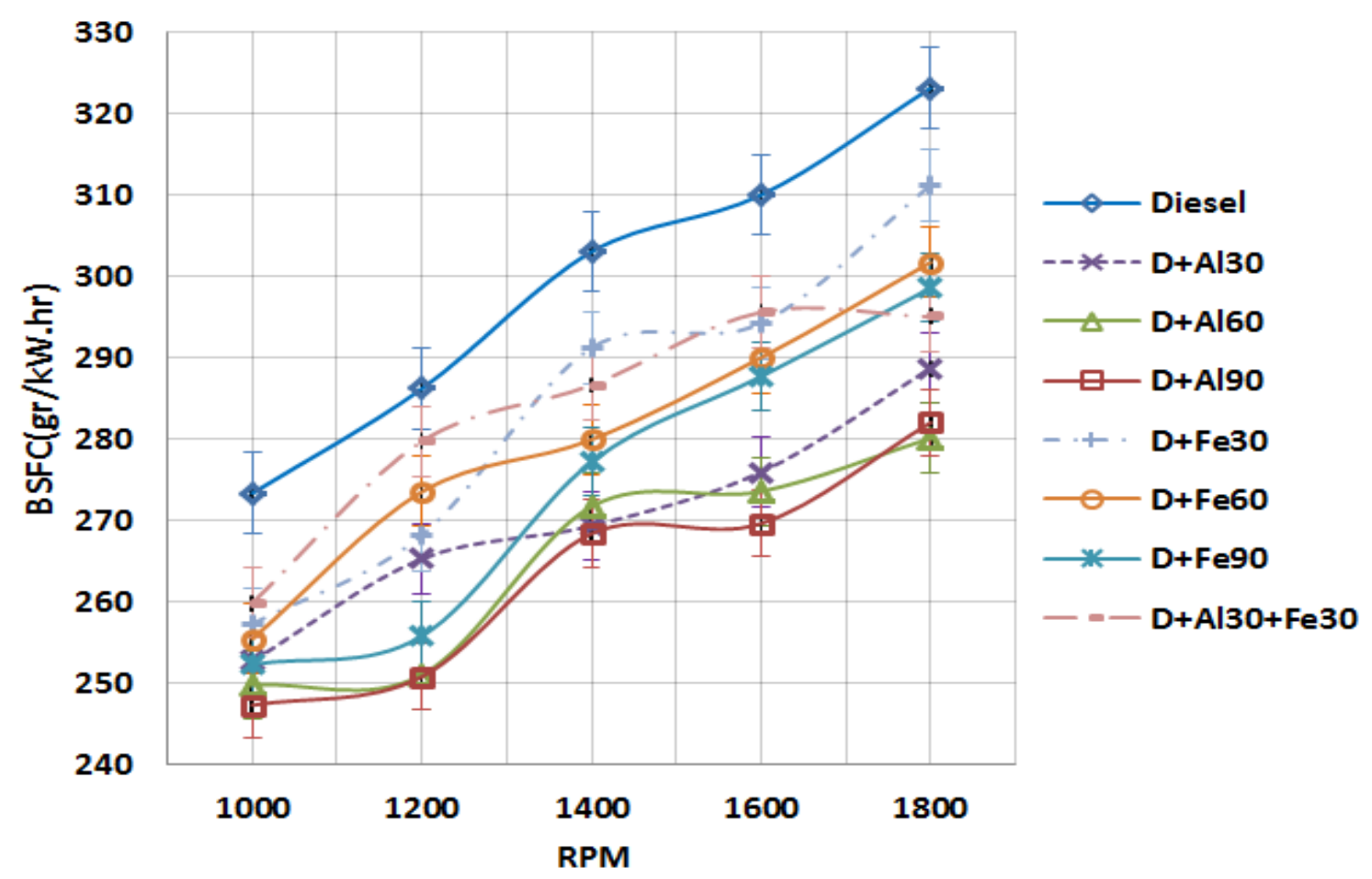

Figure 12: BSFC values versus rotational speed for various fuel blends at $50 \%$ engine load

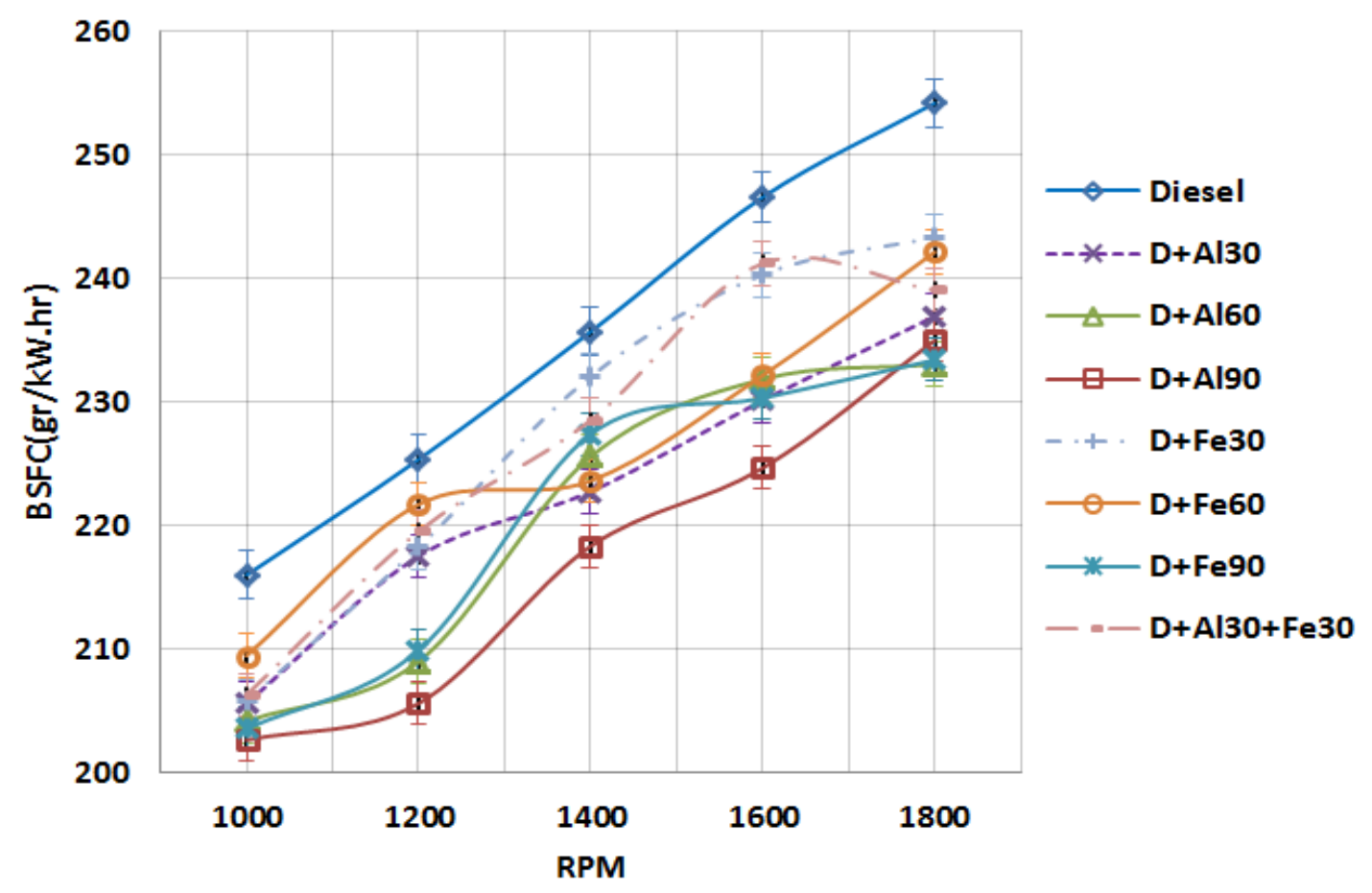

Figure 13: BSFC values versus rotational speed for various fuel blends at full engine load 
Based on the results, using aluminum oxide and iron (III) oxide nanoparticles caused a significant decrease in BSFC. Given that BSFC is directly related to brake power and combustion efficiency, the oxygen content in the blend by nanoparticles enhances the combustion efficiency and consequently improves BSFC (Hosseinzadeh Samani et al. 2020). Moreover, nanoparticles have activity as a catalyst and provide oxygen to accelerate combustion(Arul Mozhi Selvan et al. 2014). These additives also enhance the combustion parameters as a result of their large ratio of surface/volume; therefore the brake specific fuel consumption is improved (Shaafi and Velraj 2015)

Based on the results, $\mathrm{Al}_{2} \mathrm{O}_{3}$ nanoparticles were more effective than iron (III) oxide nanoparticles as far as BSFC reduction is concerned which could be because alumina nanoparticles cause higher fuel atomization and more complete combustion. Moreover, the higher density of $\mathrm{Al}_{2} \mathrm{O}_{3}$ fuel blends compared with $\mathrm{Fe}_{2} \mathrm{O}_{3}$ fuel blends produced a higher brake power for the same volume of fuel injected into the combustion chamber, hence the reduction in BSFC. According to the results, the BSFC decreased with increasing the load applied on the engine for all fuel blends owing to the higher combustion temperature which results in better combustion conditions and produces higher brake power(Shirneshan et al. 2014). D+A190 and D+Fe30 fuel blends had the maximum (8.2\%) and minimum (4.3\%) decrease in BSFC in comparison with D100, respectively. However, some other authors reported 1.2\%(Gumus et al. 2016), 12\%(El-Seesy et al. 2018), and 6\% (Aalam et al. 2015) reduction in BSFC for diesel engine fuelled with nanoparticle additives.

Based on the results, the minimum BSFC (203 g/kW.h) occurred in D+A190 blend at the speed of $1000 \mathrm{rpm}$, and the highest BSFC (254 g/kW.h) belonged to neat diesel fuel at $1800 \mathrm{rpm}$ under full engine load. Besides, the D+A190 blend had the minimum BSFC (247 g/kW.h) at the speed of $1000 \mathrm{rpm}$ and the maximum BSFC (323 g/kW.h) belonged to neat diesel fuel at $1800 \mathrm{rpm}$ under $50 \%$ engine load.

\subsection{Effect of nanoparticles on brake thermal efficiency}

Brake thermal efficiency (BTE) is defined as the ratio of mechanical energy (output energy) to the chemical energy (input). The BTE values versus rotational speed for different fuel blends under $50 \%$ and full engine loads are shown in Figures 13 and 15, respectively. 


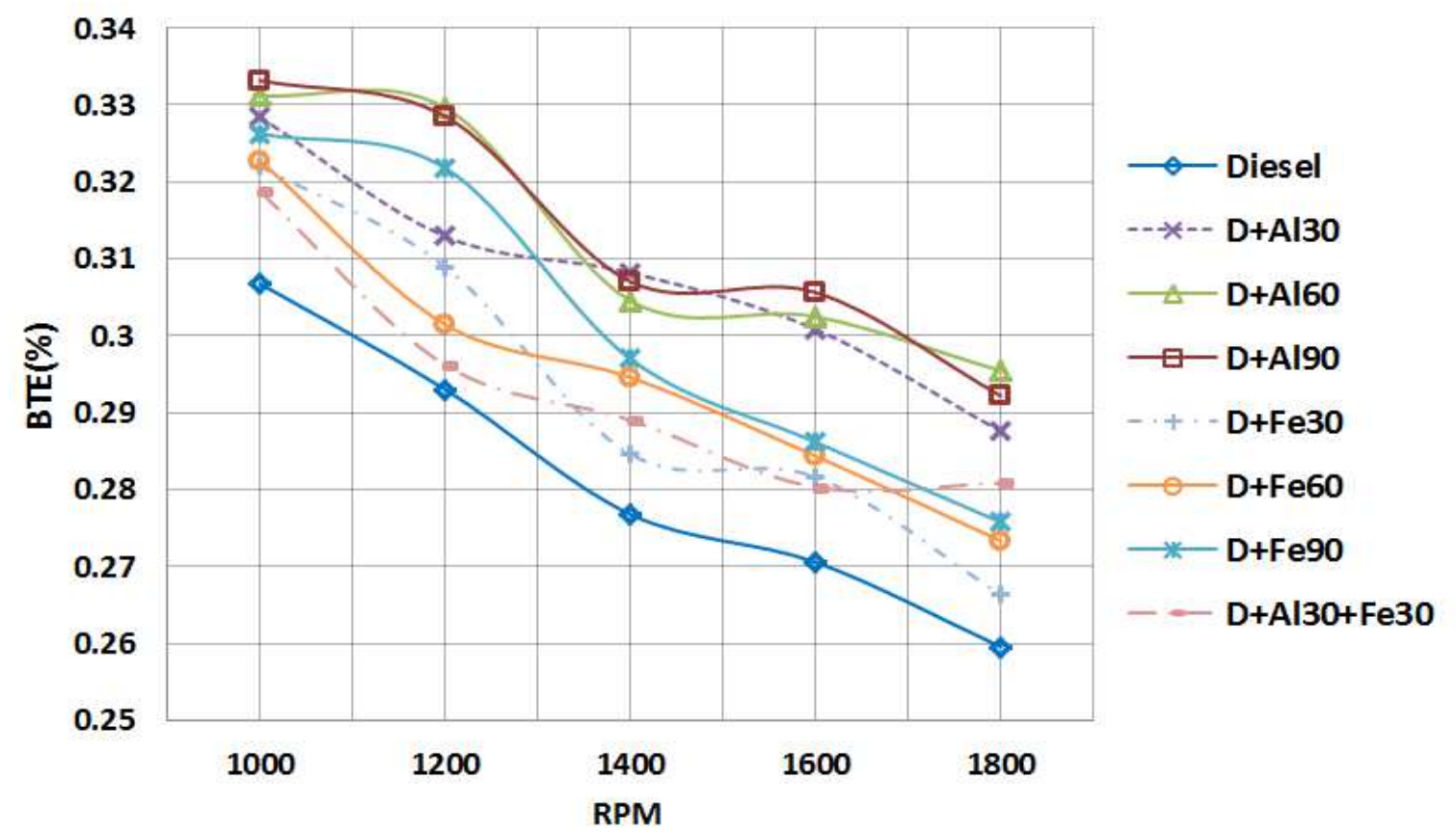

Figure 14: BTE values versus rotational speed for different nanoparticle-diesel fuel blends at 50\% engine load

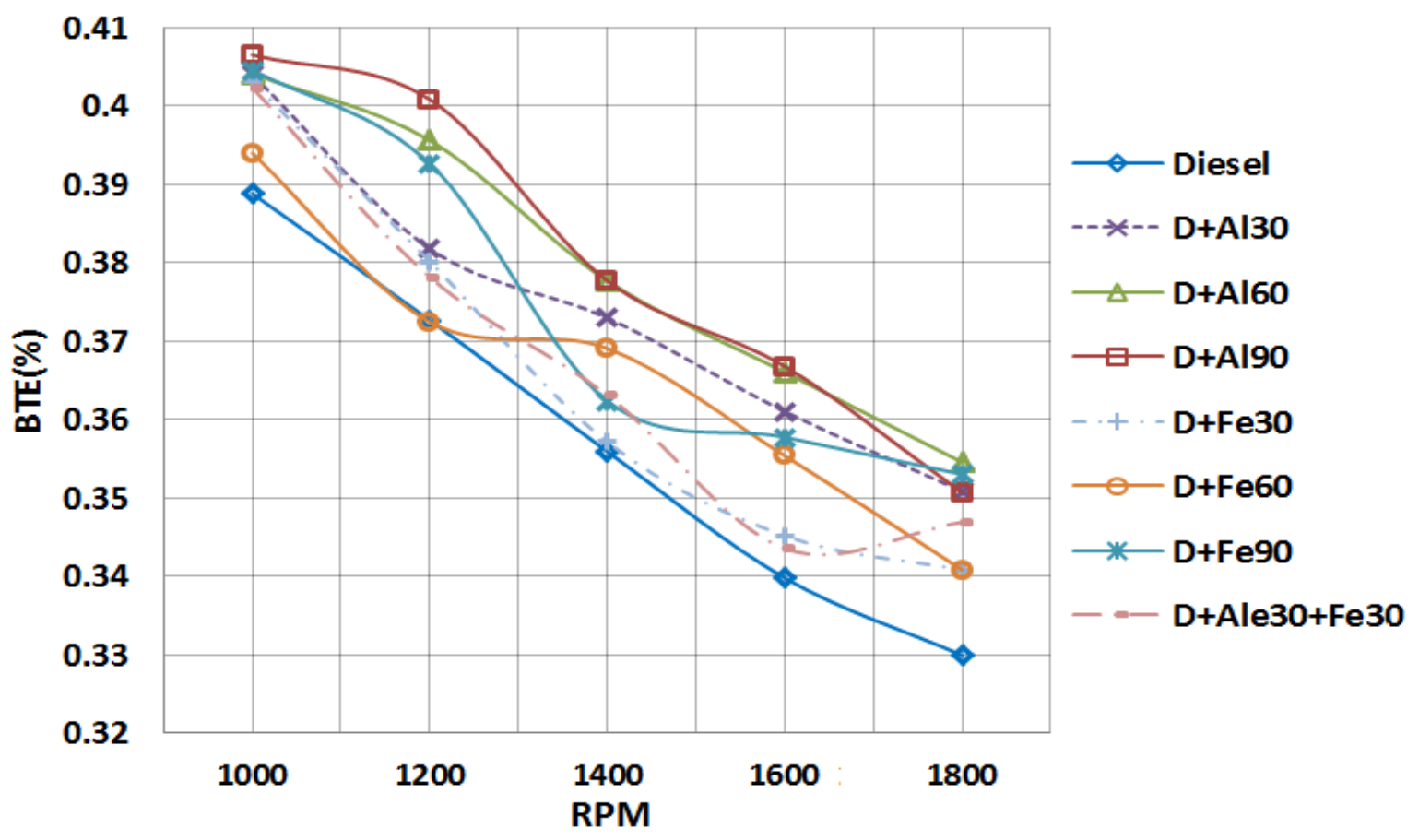

Figure 15: BTE values versus rotational speed for different nanoparticle-diesel fuel blends at full engine load

Aluminium oxide and iron (III) oxide nanoparticles resulted in a significant improvement in BTE. Given that BTE is inversely related to the BSFC and LHV of the fuels and is mostly influenced by BSFC, the improvement in the fuel economy of the blends entailed a better thermal efficiency. Moreover, the enhanced ratio of the surface/volume of the nanoparticles favouring better 
combustion and resulted in improved brake thermal efficiency (Basha and Anand 2011; Prabu and Anand 2016).

Based on the results, $\mathrm{Al}_{2} \mathrm{O}_{3}$ nanoparticles were more effective than $\mathrm{Fe}_{2} \mathrm{O}_{3}$ nanoparticles in producing higher brake thermal efficiency probably because of the lower BSFC of $\mathrm{Al}_{2} \mathrm{O}_{3}$ fuel blends resulting in higher BTE. D+A190 and D+Fe30 fuel blends had the maximum (6.6\%) and minimum (3\%) improvement in BTE compared to neat diesel fuel, respectively. Although other researchers obtained 18.8\% (Chen et al. 2018), 2.5\% (Aalam et al. 2015), 17.9\% (Shaafi and Velraj 2015) and 9\% (Attia et al. 2014) improvement in BTE with the addition of nanoparticles in diesel fuel.

\subsection{Effect of nanoparticles on exergy efficiency}

Figure 16 shows the impact of fuel blends on the exergy efficiency of the engine at various engine speeds and full load.

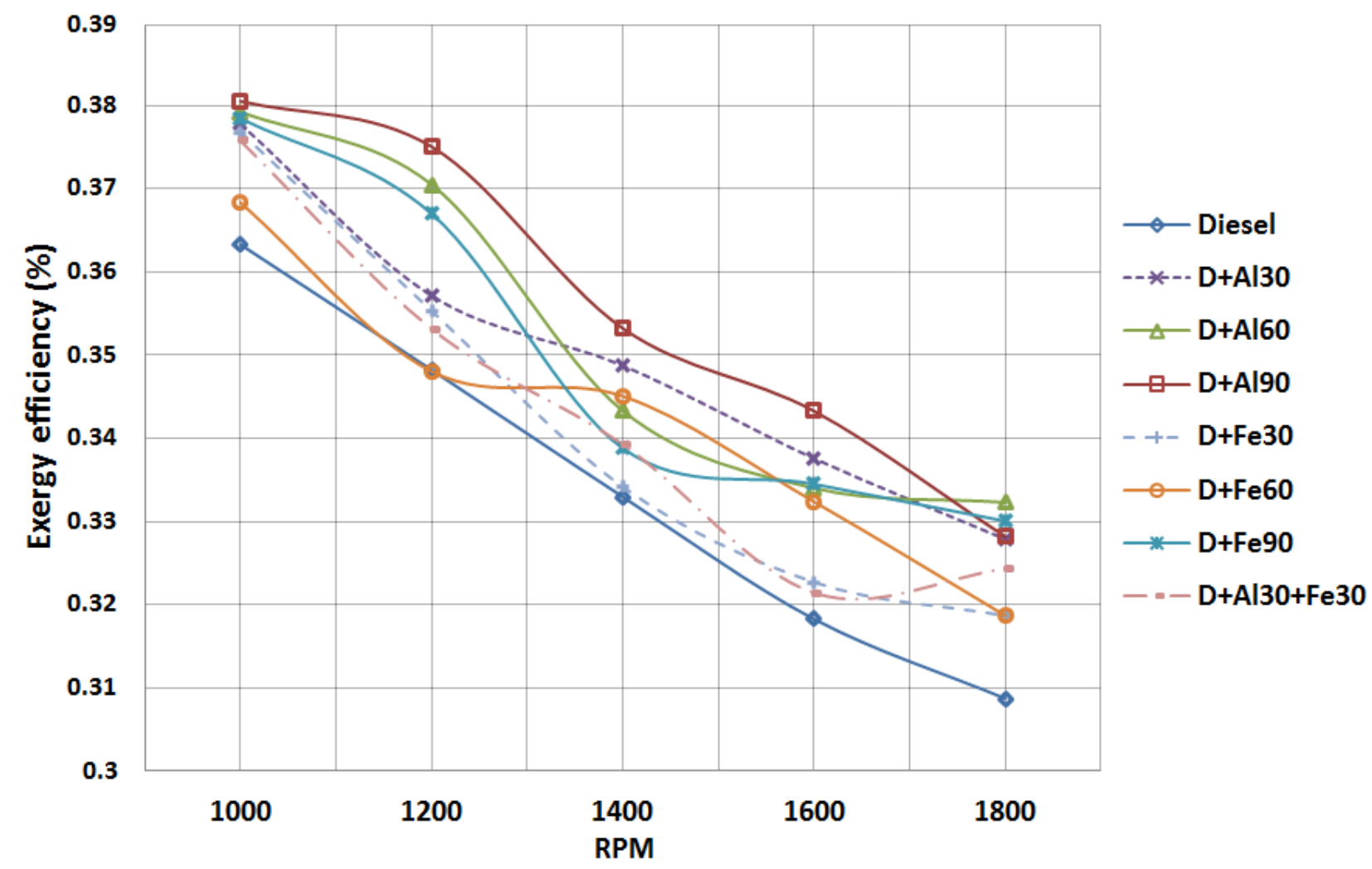

Figure 16: Exergy efficiency values versus rotational speed for different nanoparticle-diesel fuel blends at full engine load

Similar to BTE, $\mathrm{Al}_{2} \mathrm{O}_{3}$ nanoparticle fuel blends had a higher exergy efficiency compared to $\mathrm{Fe}_{2} \mathrm{O}_{3}$ nanoparticles which is probably due to the lower $\mathrm{BSFC}$ of $\mathrm{Al}_{2} \mathrm{O}_{3}$ fuel blends increasing the energy efficiency. According to the results, neat diesel had the lowest value (30.8\%) of exergy efficiency. Moreover, the maximum exergy efficiency $(38 \%)$ belonged to the D+A190 fuel blend while the minimum exergy efficiency $(31.9 \%)$ occurred in D+Fe30 among all fuel blends with nanoparticle 
additives. Furthermore, the exergy efficiency dropped with increasing engine speed because of the sharp rise in BSFC at higher rpms.

\subsection{Effect of nanoparticles on $\mathrm{CO}$ emission}

Figure 17 shows the impact of fuel blends on the $\mathrm{CO}$ emission of the engine. According to the figure, $\mathrm{CO}$ emission decreases with increasing the engine load from 25 to $100 \%$ (full load) for all fuel blends, because at higher loads, the combustion temperature increases which results in better combustion condition and lower carbon monoxide emission (Shirneshan et al. 2016a, 2016b). The results further showed that with the increase in nanoparticle fraction, $\mathrm{CO}$ emission was reduced. High ratio of surface to volume and the catalytic effect of nanoparticles enhance the burning efficiency of fuel blends and reduce $\mathrm{CO}$ formation (Sivakumar et al. 2018). Moreover, $\mathrm{Al}_{2} \mathrm{O}_{3}$ and $\mathrm{Fe}_{2} \mathrm{O}_{3}$ addition shortened the ID time which yields inefficient combustion and lower CO production (Motamedifar and Shirneshan 2018). The presence of sufficient active oxygen in nanoparticle additives improved combustion, especially at higher engine loads, and reduced CO emission (Aalam et al. 2015; George et al. 2015). Concerning CO emission reduction, the effect of $\mathrm{Fe}_{2} \mathrm{O}_{3}$ was slightly more than $\mathrm{Al}_{2} \mathrm{O}_{3}$ nanoparticle additives. However, the minimum $(8 \%)$ and maximum $(21 \%)$ decrease in $\mathrm{CO}$ emission with respect to pure diesel fuel were observed after using D+Fe30 and D+A190 fuel blends. Moreover, similar conclusions were also drawn by other authors (El-Seesy et al. 2018; Sivakumar et al. 2018). For example, Gumus et al. (2016) reported that the $\mathrm{CO}$ emissions decrease by $11 \%$ with the addition of $\mathrm{Al}_{2} \mathrm{O}_{3}$ into diesel fuel.

Based on the results, the minimum $\mathrm{CO}$ emission $(0.88 \%)$ belonged to the $\mathrm{D}+\mathrm{Fe} 90$ blend at full engine load, and the highest amount of $\mathrm{CO}$ emission (1.83\%) occurred in pure diesel fuel at $25 \%$ engine load.

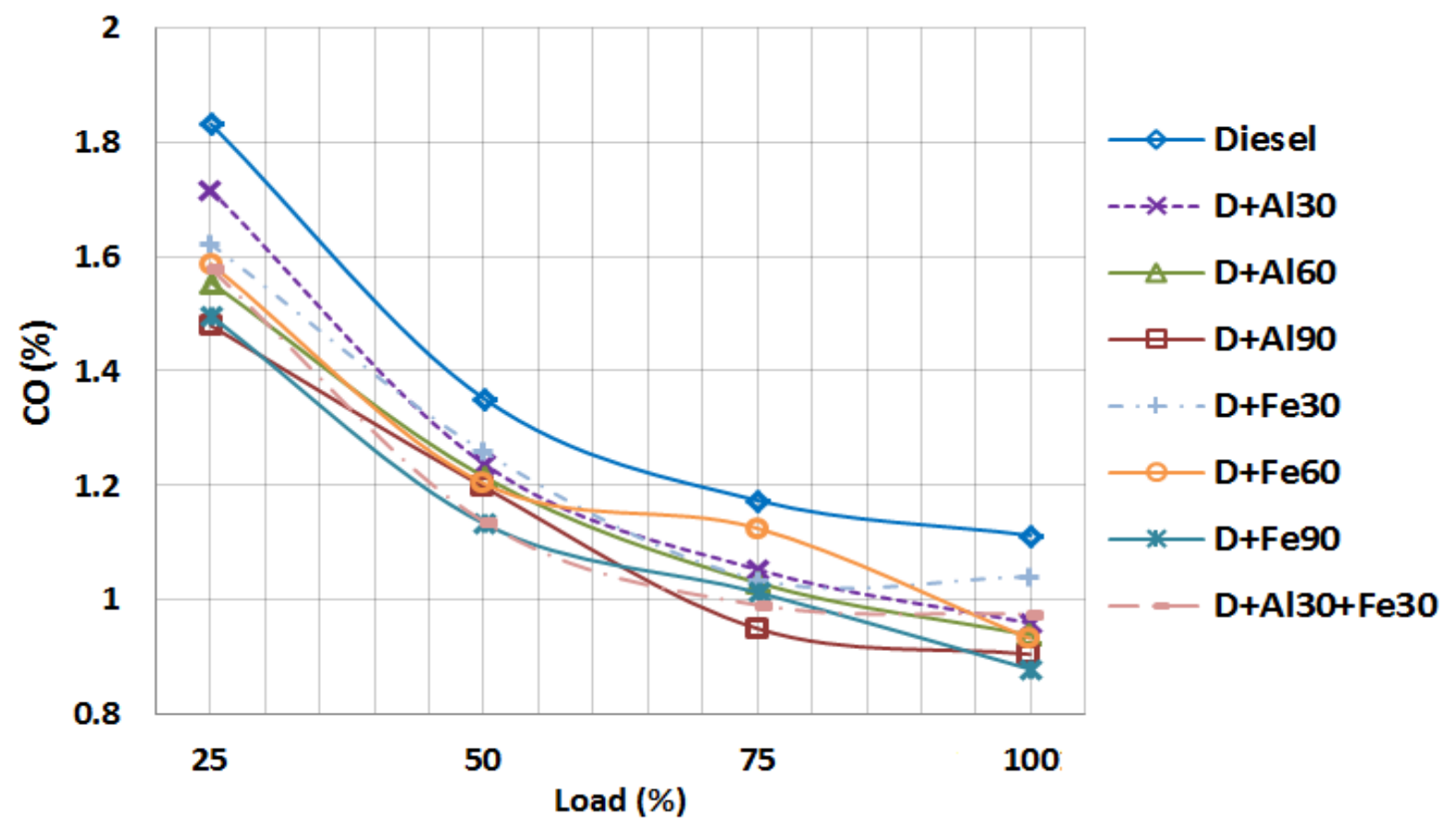

Figure 17: Variations of the $\mathrm{CO}$ emission against engine load for different nanoparticle-diesel fuel blends 


\subsection{Effect of nanoparticles on NOx emission}

Nitrous oxides in the exhaust gas are contained a mixture of $\mathrm{NO}$ and $\mathrm{NO}_{2}$. The oxygen and nitrogen existing in the air react at very high temperatures. Therefore, high temperature and available oxygen are the main parameters for $\mathrm{NO}_{\mathrm{x}}$ production. The variations in $\mathrm{NO}_{\mathrm{x}}$ emission versus engine load regarding different nanoparticle-diesel fuel blends are shown in Figure 19.

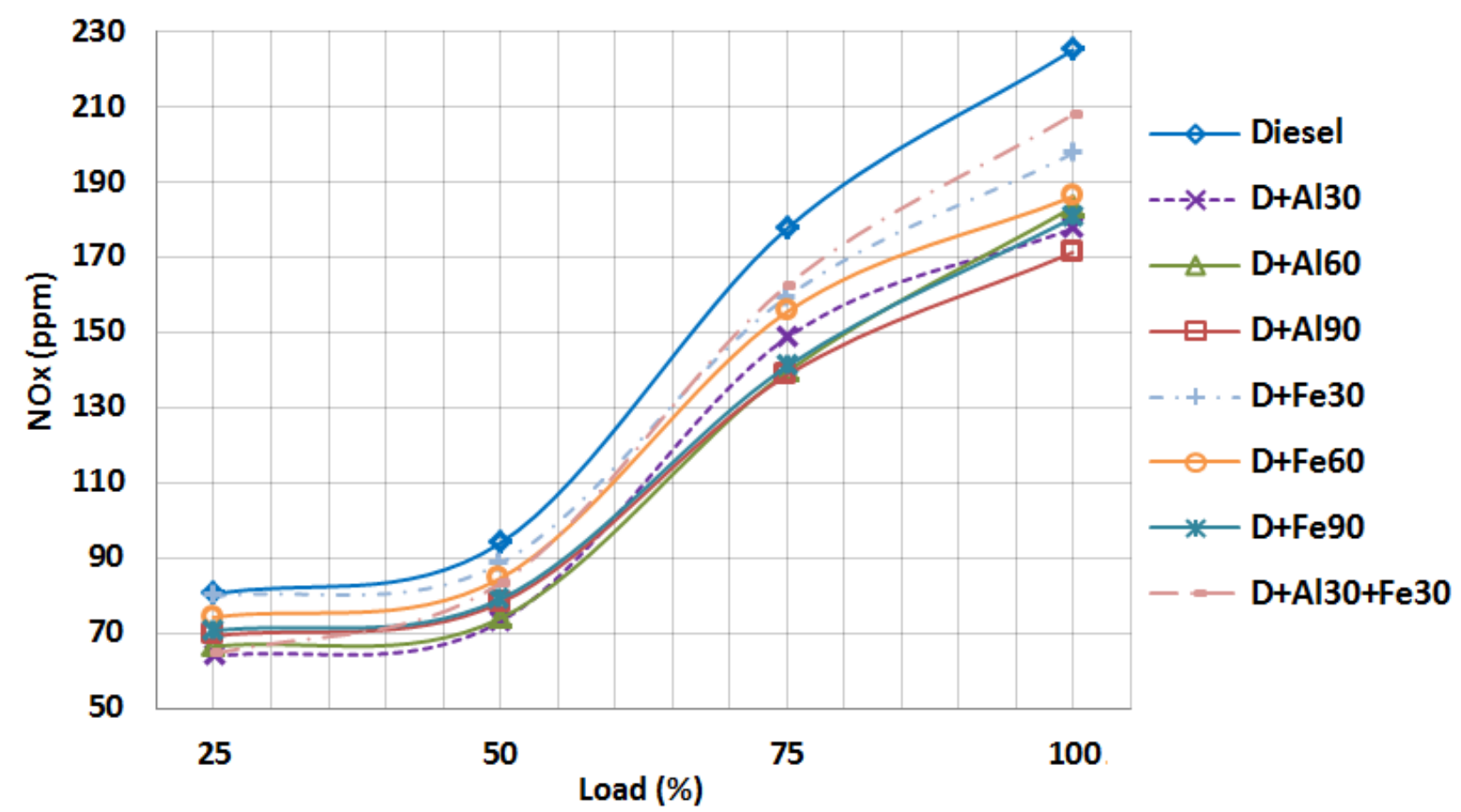

Figure 19: Variations of the $\mathrm{NO}_{\mathrm{x}}$ emission versus engine load for different nanoparticle-diesel fuel blends

As seen in this figure, the concentration of $\mathrm{NO}_{\mathrm{x}}$ in the exhaust gas of the engine increased at higher engine loads, which is related to the increase in combustion temperature at higher engine loads (Hojati 2019, Salehian 2020). Based on the findings, a significant reduction (20\% on average) was observed in $\mathrm{NO}_{\mathrm{x}}$ emission following the addition of nanoparticles (especially $\mathrm{Al}_{2} \mathrm{O}_{3}$ nanoparticles) to neat fuel diesel. Similar results were reported by other researchers (El-Seesy et al. 2018, Gumus et al. 2016). However, some authors reported the reverse change in $\mathrm{NO}_{\mathrm{x}}$ emission with the addition of nanoparticles in diesel fuel (Shaafi 2015; Sivakumar et al. 2018).

The reason for this reduction is the thermal stability and catalytic activity of fuel blend blends which facilitate reaction completion and form the final products from the $\mathrm{HC}$ compounds with a lowest thermal breakdown, causing a reduction in active radicals to form NOx (Sadhik Basha 2013, Sajith et al. 2010). Besides, nanoparticles can scavenge the NO radicals that cause a reduction in NOx for fuel blends with respect to neat diesel (Dowding et al. 2012). Also, NOx formation is related to the nitrogen oxidation at the highest combustion temperature (Vairamuthu et al. 2016). Therefore, neat diesel with a prolonged ignition delay provided a greater chance for 
the formation of a premixed mixture and higher peak combustion temperature compared with nano fuels and produces higher NOx formation (Lee and Bae 2011).

The results also showed that the NOx emission of $\mathrm{Fe}_{2} \mathrm{O}_{3}$ nano fuels is higher than that of $\mathrm{Al}_{2} \mathrm{O}_{3}$ nano fuels. The reason is related to the advanced combustion phasing for $\mathrm{Fe}_{2} \mathrm{O}_{3}$ nano-fuels that causes higher combustion temperature and resulted in higher NOx formation.

According to the results, the D+Fe30+AL30 fuel blend did not significantly improve $\mathrm{NO}_{\mathrm{x}}$ emission compared to other fuel blend blends, particularly at higher loads. This is because of the higher portion of the premixed burn phase combustion of this fuel which enhances the combustion temperature and NOx emissions (Aalam et al. 2015; Shaafi 2015).

Findings also showed that neat diesel fuel produced the maximum amount of $\mathrm{NO}_{\mathrm{x}}$ emission (225ppm) at full engine load, while the minimum amount of $\mathrm{NO}_{\mathrm{x}}$ emission (63.8ppm) belonged to $\mathrm{D}+\mathrm{A} 130$ at $25 \%$ engine load.

\subsection{Effect of nanoparticles on $\mathrm{SO}_{2}$ emission}

Sulfur oxides are produced as a result of the reaction between sulfur content of diesel fuel and oxygen. However, even low amounts of $\mathrm{SO}_{2}$ in the exhaust gas are produced from the combustion of the sulfur content of the fuel. Sulfur oxides ensue corrosion in engine parts, and their emission to the atmosphere leads to pollution and acid rain (Pulkrabek 1997; Tikhomirov et al. 2006).

Based on the results (Figure 19), $\mathrm{SO}_{2}$ concentration in the exhaust gas increased at higher engine loads possibly due to the thermal breakdown of the sulfur compounds in the fuel, causing $\mathrm{SO}_{2}$ formation (Nedayali 2016).

The results further showed that with increasing the fraction of nanoparticles in the fuel blend, the emission of $\mathrm{SO}_{2}$ pollutant was reduced. Similarly, some other authors also reported that the $\mathrm{SO}_{2}$ emission decreased with the addition of nanoparticles to neat diesel (Karthikeyan 2016; Sabet Sarvestany et al. 2014).

Based on the results, the lowest amount of $\mathrm{SO}_{2}$ emissions was observed in $\mathrm{D}+\mathrm{A} 190$ and $\mathrm{D}+\mathrm{Fe} 90$ fuel blends. This reduction originates from the high ratio of surface to volume and catalytic properties of nanoparticles that enhance the combustion efficiency of fuel blends and reduce $\mathrm{SO}_{2}$ (El-Seesy et al. 2018; Sivakumar et al. 2018). Moreover, $\mathrm{Al}_{2} \mathrm{O}_{3}$ and $\mathrm{Fe}_{2} \mathrm{O}_{3}$ addition reduced the ignition delay time, resulting in better combustion and lower $\mathrm{SO}_{2}$ production (Gumus et al. 2016). The findings also revealed that the influence of $\mathrm{Fe}_{2} \mathrm{O}_{3}$ nanoparticle was more than aluminum oxide nanoparticle as regards reducing $\mathrm{SO}_{2}$ emissions.

The highest amount of $\mathrm{SO}_{2}$ emission (39.1ppm) was seen in neat diesel fuel at full load while the lowest $(9.6 \mathrm{ppm})$ occurred at $25 \%$ engine load in the D+A190 fuel blend. 


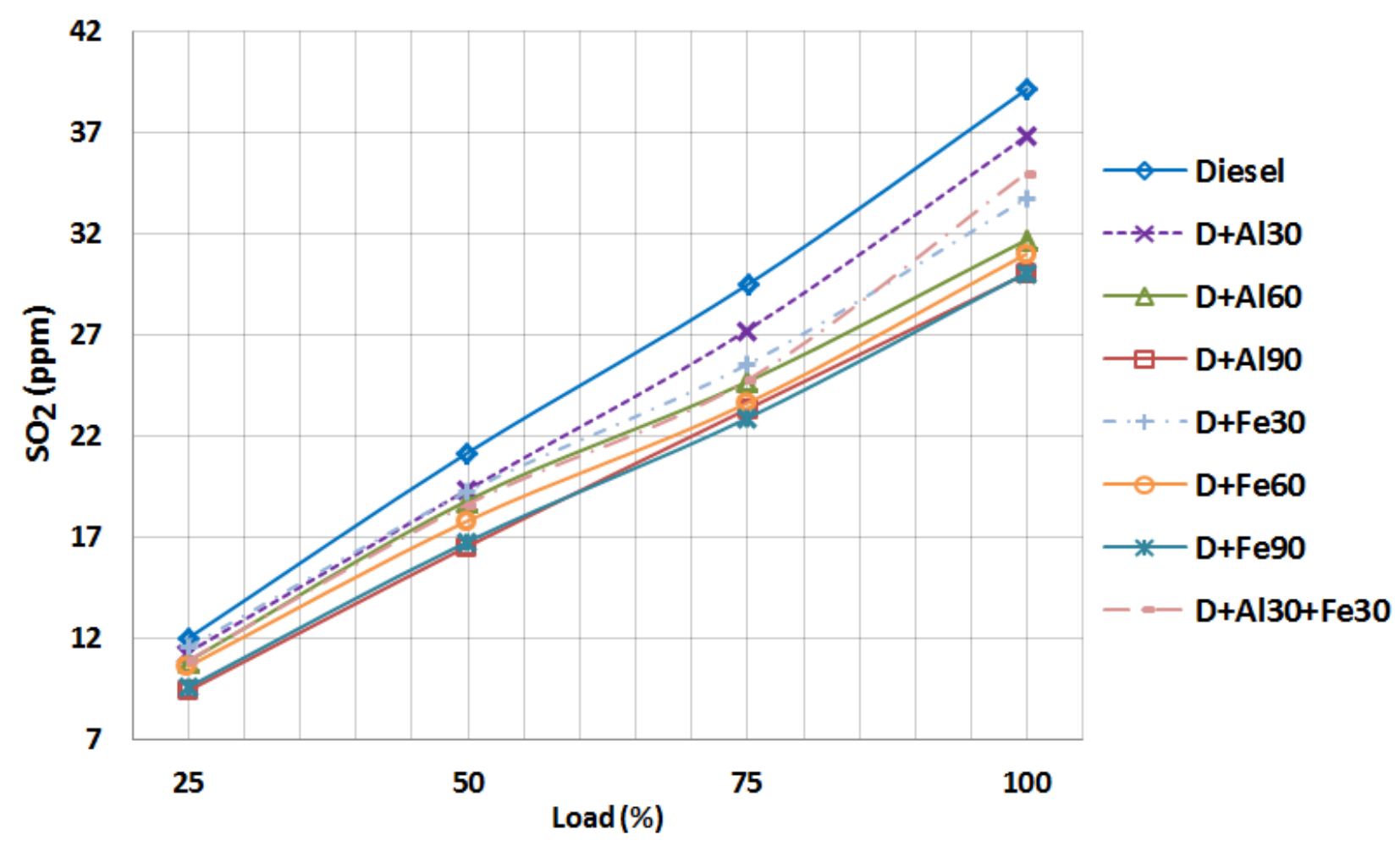

Figure 19: Variations of the $\mathrm{SO}_{2}$ emission against engine load for different nanoparticle-diesel fuel blends

\subsection{Cost analysis}

Table 5 shows the cost analysis of using nanoparticles with diesel fuel in the CI engine. According to the results, the BSFC decreased following the addition of nanoparticles in neat diesel and led to lower fuel consumption. Table 5 presents the calculations of reduction in fuel consumption and cost saving per $1000 \mathrm{kWh}$ output energy from the engine at $1800 \mathrm{rpm}$ under full load. The diesel fuel price was considered as 0.78 US Dollars per litre. Also, the price of $1 \mathrm{~kg} \mathrm{Al}_{2} \mathrm{O}_{3}$ and $\mathrm{Fe}_{2} \mathrm{O}_{3}$ nanoparticles (US Research Nanomaterials Inc.) were 185 and 348 US Dollars, respectively. Although the addition of nanoparticles to conventional diesel fuel increased the fuel cost, the results indicated that there is still room for fuel consumption cost savings of approximately 7 to 17 US Dollars per $1000 \mathrm{kWh}$ output energy from the engine by use of nanoparticles. For example, the BSFC for the D+Al30+Fe30 blend is $239 \mathrm{~g} / \mathrm{kW} . \mathrm{h}$ and for neat diesel is $255 \mathrm{~g} / \mathrm{kW} . \mathrm{h}$ at $1800 \mathrm{rpm}$ under full load. Therefore, for $1 \mathrm{kWh}$ output energy at the same conditions, there is around $16 \mathrm{gr}$ or $19 \mathrm{cc}$ reduction in fuel consumption which means the cost of 0.0145 US Dollars. However, the mass of nanoparticles used will be 0.01434 gr at this condition which means the cost of 0.00382 US Dollars. Thus, the calculation for $1000 \mathrm{kWh}$ output energy shows approximately 11 US Dollars cost saving. 
Table 5: Cost analysis results

\begin{tabular}{c|c|c|c|c|c}
\hline Fuel & $\begin{array}{c}\text { Reduction in the } \\
\text { fuel consumption } \\
\text { per 1 kWh output } \\
\text { energy compared } \\
\text { to neat diesel(gr) }\end{array}$ & $\begin{array}{c}\text { Reduction in fuel } \\
\text { consumption per 1 kWh } \\
\text { output energy compared } \\
\text { to neat diesel (lit) }\end{array}$ & $\begin{array}{c}\text { Mass of } \\
\text { consumed } \\
\text { nanoparticles } \\
\text { (gr) }\end{array}$ & $\begin{array}{c}\text { Cost of } \\
\text { nanoparticles } \\
\text { addition in neat } \\
\text { diesel (\$) }\end{array}$ & $\begin{array}{c}\text { Cost saving } \\
\text { compared to neat } \\
\text { diesel (\$) per 1 } \\
\mathrm{kWh} \text { output energy }\end{array}$ \\
\hline $\mathrm{D}+\mathrm{Al30}$ & 17.24 & 0.0211 & 0.0071 & 0.0013 & 0.01517 \\
\hline $\mathrm{D}+\mathrm{Al60}$ & 21.13 & 0.0259 & 0.0139 & 0.0026 & 0.01761 \\
\hline $\mathrm{D}+\mathrm{Al90}$ & 19.19 & 0.0235 & 0.0211 & 0.0039 & 0.01443 \\
\hline $\mathrm{D}+\mathrm{Fe30}$ & 10.84 & 0.0133 & 0.0072 & 0.0025 & 0.00782 \\
\hline $\mathrm{D}+\mathrm{Fe} 60$ & 12.04 & 0.0148 & 0.0145 & 0.0050 & 0.00646 \\
\hline $\mathrm{D}+\mathrm{Fe90}$ & 20.76 & 0.0254 & 0.0210 & 0.0073 & 0.01254 \\
\hline $\mathrm{D}+\mathrm{Al30+Fe30}$ & 15.13 & 0.0186 & $0.0072 \mathrm{Al}$ & 0.0038 & 0.01064
\end{tabular}

\section{Conclusion}

In this research, the engine tests were performed to evaluate the effect of using $\mathrm{Fe}_{2} \mathrm{O}_{3}$ and $\mathrm{Al}_{2} \mathrm{O}_{3}$ nanoparticle additives with fractions of 30,60 and $90 \mathrm{ppm}$ on the performance (brake power, torque, $\mathrm{BSFC})$ and emission $\left(\mathrm{CO}, \mathrm{NO}_{\mathrm{x}}\right.$, and $\left.\mathrm{SO}_{2}\right)$ characteristics of a $\mathrm{CI}$ engine. The most important findings of this study are:

- In general, fuel blends and higher amounts of nanoparticles in fuel mixture increased the power and torque (up to 8\%) and reduce BSFC (up to 9\%) compared to neat diesel fuel at all rotational speeds owing to the shorter ID, oxygen addition to the blend, high ratio of surface/volume and better thermal conductivity which increases the combustion efficiency.

- The peak combustion pressure increased by $4 \%$ and the HRR was improved by $15 \%$ with respect to neat diesel with nanoparticles addition. Moreover, the rate of pressure rise increased by $18 \%$ in comparison with neat diesel with nano-metallic additives.

- D+Fe90 blend has the highest combustion pressure and the maximum HRR among other fuel blends.

- The effect of $\mathrm{Fe}_{2} \mathrm{O}_{3}$ nanoparticles on brake power and brake torque is more than aluminum oxide $\left(\mathrm{Al}_{2} \mathrm{O}_{3}\right)$ nanoparticles. On the other hand, $\mathrm{Al}_{2} \mathrm{O}_{3}$ nanoparticles showed better results in reducing BSFC and producing higher brake thermal efficiency compared with that of $\mathrm{Fe}_{2} \mathrm{O}_{3}$ nanoparticle additives.

- BTE was improved by $14 \%$ following the addition of nanoparticles.

- Similar to brake thermal efficiency, $\mathrm{Al}_{2} \mathrm{O}_{3}$ nanoparticle fuel blends, owing to their lower $\mathrm{BSFC}$, have a higher exergy efficiency compared to $\mathrm{Fe}_{2} \mathrm{O}_{3}$ nanoparticles.

- With the increase in nanoparticle concentration, $\mathrm{CO}$ emission was reduced by $21 \%$.

- $\mathrm{Fe}_{2} \mathrm{O}_{3}$ is slightly more effective than $\mathrm{Al}_{2} \mathrm{O}_{3}$ nanoparticle additives as far as reduction in $\mathrm{CO}$ emission is concerned.

- There was a significant reduction (up to 24\%) in $\mathrm{NO}_{\mathrm{x}}$ emission by addition of nanoparticles (especially $\mathrm{Al}_{2} \mathrm{O}_{3}$ ) to neat fuel diesel owing to the thermal stability and catalytic behavior of fuel blends reducing the active radical to form NOx.

-At higher fractions of nanoparticles, the emission of $\mathrm{SO}_{2}$ pollutant decreased (up to 23\%) and the lowest amount of $\mathrm{SO}_{2}$ emissions was observed in $\mathrm{D}+\mathrm{A} 190$ and $\mathrm{D}+\mathrm{Fe} 90$ fuel blends. 
-The influence of $\mathrm{Fe}_{2} \mathrm{O}_{3}$ nanoparticle is more than $\mathrm{Al}_{2} \mathrm{O}_{3}$ nanoparticle in terms of reducing $\mathrm{SO}_{2}$ emission.

- The cost analysis results indicated that the fuel consumption cost can be saved by about 7 to 17 US Dollars per $1000 \mathrm{kWh}$ output energy with the use of nanoparticles.

- Generally, both nanoparticle additives improved the combustion parameters and performance and emission characteristics of the engine. Also, $\mathrm{Fe}_{2} \mathrm{O}_{3}$ nanoparticle additives have better results regarding the engine combustion and performance compared with $\mathrm{Al}_{2} \mathrm{O}_{3}$ nanoparticle additives. On the other hand, the addition of $\mathrm{Al}_{2} \mathrm{O}_{3}$ nanoparticle to pure diesel can improve further the emission characteristics of the engine and fuel cost. Overall, the $\mathrm{Fe}_{2} \mathrm{O}_{3}-\mathrm{Al}_{2} \mathrm{O}_{3}$ hybrid fuel blend is preferred if the performance and emission characteristics of the engine are both considered.

- The effect of fuel blends on unburned hydrocarbon and particulate matter (PM) emissions, the impact of using higher concentrated nanoparticle-diesel fuel blends, and the effect of using nanoparticle biofuels are proposed for future studies.

\section{Declarations}

\section{Conflict of interest statement}

The authors state that there is no conflict of interest.

\section{References}

Aalam CS, Saravanan CG, Kannan M (2015) Experimental investigations on a CRDI system assisted diesel engine fuelled with aluminium oxide nanoparticles blended biodiesel. Alexandria Engineering Journal 54:351-358. doi: https://doi.org/10.1016/j.aej.2015.04.009

Adzmi MA, Abdullah A, Abdullah Z, Mrwan AG (2019) Effect of Al2O3 and SiO2 Metal Oxide Nanoparticles Blended with POME on Combustion, Performance and Emissions Characteristics of a Diesel Engine International. Journal of Automotive and Mechanical Engineering 16:6859-6873 doi:doi.org/10.15282/ijame.16.3.2019.03.0515

Amiri M, Shirneshan A (2020) Effects of air swirl on the combustion and emissions characteristics of a cylindrical furnace fueled with diesel-biodiesel-n-butanol and diesel-biodiesel-methanol blends. Fuel 268:117295 doi:https://doi.org/10.1016/j.fuel.2020.117295

Annamalai M, Dhinesh B, Nanthagopal K, SivaramaKrishnan P, Isaac Joshua Ramesh Lalvani J, Parthasarathy M, Annamalai K (2016) An assessment on performance, combustion and emission behavior of a diesel engine powered by ceria nanoparticle blended emulsified biofuel. Energy Conversion and Management 123:372-380 doi:https://doi.org/10.1016/j.enconman.2016.06.062

Arul Mozhi Selvan V, Anand RB, Udayakumar M (2014) Effect of Cerium Oxide Nanoparticles and Carbon Nanotubes as fuel-borne additives in Diesterol blends on the performance, combustion and emission characteristics of a variable compression ratio engine. Fuel 130:160-167 doi:https://doi.org/10.1016/j.fuel.2014.04.034

- $\quad$ Attia AMA, El-Seesy AI, El-Batsh HM, Shehata MS (2014) Effects of Alumina Nanoparticles Additives Into Jojoba Methyl Ester-Diesel Mixture on Diesel Engine Performance. ASME 2014 International Mechanical Engineering Congress \& Exposition V06BT07A019 doi:10.1115/IMECE2014-39988 
Basha JS, Anand RB (2011) An experimental investigation in a diesel engine using carbon nanotubes blended waterdiesel emulsion fuel. Proceedings of the Institution of Mechanical Engineers, Part A: Journal of Power and Energy 225:279-288 doi:10.1177/2041296710394247

Basu S, Miglani A (2016) Combustion and heat transfer characteristics of nanofluid fuel droplets: A short review. International Journal of Heat and Mass Transfer 96:482-503 doi:https://doi.org/10.1016/j.ijheatmasstransfer.2016.01.053

Braun A, Huggins FE, Kelly KE, Mun BS, Ehrlich SN, Huffman GP (2006) Impact of ferrocene on the structure of diesel exhaust soot as probed with wide-angle X-ray scattering and C(1s) NEXAFS spectroscopy. Carbon 44:2904-2911 doi:https://doi.org/10.1016/j.carbon.2006.05.051

Chen AF, Akmal Adzmi M, Adam A, Othman MF, Kamaruzzaman MK, Mrwan AG (2018) Combustion characteristics, engine performances and emissions of a diesel engine using nanoparticle-diesel fuel blends with aluminium oxide, carbon nanotubes and silicon oxide. Energy Conversion and Management 171:461477 doi:https://doi.org/10.1016/j.enconman.2018.06.004

D'Silva R, Binu KG, Bhat T (2015) Performance and Emission Characteristics of a C.I. Engine Fuelled with Diesel and TiO2 Nanoparticles as Fuel Additive. Materials Today: Proceedings 2:3728-3735 doi:https://doi.org/10.1016/j.matpr.2015.07.162

Dowding JM, Dosani T, Kumar A, Seal S, Self WT (2012) Cerium oxide nanoparticles scavenge nitric oxide radical (NO). Chemical Communications 48:4896-4898 doi:10.1039/c2cc30485f

El-Seesy AI, Attia AMA, El-Batsh HM (2018) The effect of Aluminum oxide nanoparticles addition with Jojoba methyl ester-diesel fuel blend on a diesel engine performance, combustion and emission characteristics. Fuel 224:147-166 doi:https://doi.org/10.1016/j.fuel.2018.03.076

George RO, Franc S, James SJ, John M, Sebastian G (2015) An experimental analysis on synergetic effect of multiple nanoparticle blended diesel fuel on CI engine. International Journal for Innovative Research in Science \& Technology 1:151-156

Ghadimi A, Saidur R, Metselaar HSC (2011) A review of nanofluid stability properties and characterization in stationary conditions. International Journal of Heat and Mass Transfer 54:4051-4068 doi:https://doi.org/10.1016/j.ijheatmasstransfer.2011.04.014

Gumus S, Ozcan H, Ozbey M, Topaloglu B (2016) Aluminum oxide and copper oxide nanodiesel fuel properties and usage in a compression ignition engine. Fuel 163:80-87 doi:https://doi.org/10.1016/j.fuel.2015.09.048

Hojati A, Shirneshan A (2019) Effect of compression ratio variation and waste cooking oil methyl ester on the combustion and emission characteristics of an engine. Energy \& Environment:0958305X19893045 doi:10.1177/0958305X19893045

Hosseini SH, Taghizadeh-Alisaraei A, Ghobadian B, Abbaszadeh-Mayvan A (2017) Performance and emission characteristics of a CI engine fuelled with carbon nanotubes and diesel-biodiesel blends. Renewable Energy 111:201-213 doi:https://doi.org/10.1016/j.renene.2017.04.013

Hosseinzadeh Samani B, Ansari Samani M, Shirneshan A, Fayyazi E, Najafi G, Rostami S (2020) Evaluation of an enhanced ultrasonic-assisted biodiesel synthesized using safflower oil in a diesel power generator. Biofuels 11:523-532 doi:10.1080/17597269.2019.1646542

Karthikeyan S, Prathima A (2016) Environmental effect on the impact of ferrofluid on Caulerpa Racemosa Oil methyl ester from marine macroalgae. Energy Sources, Part A: Recovery, Utilization, and Environmental Effects 38:3242-3248 doi:10.1080/15567036.2016.1143060

Lee J, Bae C (2011) Application of JP-8 in a heavy duty diesel engine. Fuel 90:1762-1770 doi:https://doi.org/10.1016/j.fuel.2011.01.032 
Li M, Zhang Q, Li G, Shao S (2015) Experimental investigation on performance and heat release analysis of a pilot ignited direct injection natural gas engine. Energy 90:1251-1260 doi:https://doi.org/10.1016/j.energy.2015.06.089

Mandilas C et al. (2016) Study of Oxidation and Combustion Characteristics of Iron Nanoparticles under Idealized and Enginelike Conditions. Energy \& Fuels 30:4318-4330 doi:10.1021/acs.energyfuels.6b00121

Mirzajanzadeh M, Tabatabaei M, Ardjmand M, Rashidi A, Ghobadian B, Barkhi M, Pazouki M (2015) A novel soluble nano-catalysts in diesel-biodiesel fuel blends to improve diesel engines performance and reduce exhaust emissions. Fuel 139:374-382 doi:https://doi.org/10.1016/j.fuel.2014.09.008

Motamedifar N, Shirneshan A (2018) An experimental study of emission characteristics from cylindrical furnace: Effects of using diesel-ethanol-biodiesel blends and air swirl. Fuel 221:233-239 doi:10.1016/j.fuel.2018.01.018

Najafi G (2018) Diesel engine combustion characteristics using nano-particles in biodiesel-diesel blends. Fuel 212:668-678 doi:https://doi.org/10.1016/j.fuel.2017.10.001

Nedayali A, Shirneshan A (2016) Experimental Study of the Effects of Biodiesel on the Performance of a Diesel Power Generator. Energy \& Environment 27:553-565 doi:10.1177/0958305X15627550

Ooi JB, Ismail HM, Swamy V, Wang X, Swain AK, Rajanren JR (2016) Graphite Oxide Nanoparticle as a Diesel Fuel Additive for Cleaner Emissions and Lower Fuel Consumption. Energy \& Fuels 30:1341-1353 doi:10.1021/acs.energyfuels.5b02162

Örs I, Sarıkoç S, Atabani AE, Ünalan S, Akansu SO (2018) The effects on performance, combustion and emission characteristics of DICI engine fuelled with TiO2 nanoparticles addition in diesel/biodiesel/n-butanol blends. Fuel 234:177-188 doi:https://doi.org/10.1016/j.fuel.2018.07.024

Ozgur T et al. (2015) Effect of nanoparticle additives on NOx emissions of diesel fuelled compression ignition engine. International Journal of Global Warming 7:487-498 doi:10.1504/IJGW.2015.070051

Patel DK, Tipre DR, Dave SR (2017) Selection and development of efficient consortia for decolorization of metal complex dyes. Toxicological \& Environmental Chemistry 99:252-264 doi:10.1080/02772248.2016.1178264

Prabu A, Anand RB (2016) Emission control strategy by adding alumina and cerium oxide nano particle in biodiesel. Journal of the Energy Institute 89:366-372 doi:https://doi.org/10.1016/j.joei.2015.03.003

Pulkrabek WW (1997) Engineering Fundamentals of the Internal Combustion Engine. Prentice Hall, New Jersey, U.S.A.

Rahman MM, Hamada KI, A. Aziz AR (2013) Characterization of the time-averaged overall heat transfer in a directinjection hydrogen-fueled engine. International Journal of Hydrogen Energy 38:4816-4830 doi:https://doi.org/10.1016/j.ijhydene.2013.01.136

Rakopoulos CD, Rakopoulos DC, Giakoumis EG, Dimaratos AM (2010) Investigation of the combustion of neat cottonseed oil or its neat bio-diesel in a HSDI diesel engine by experimental heat release and statistical analyses. Fuel 89:3814-3826 doi:https://doi.org/10.1016/j.fuel.2010.07.012

Rao SC, Srinivasa Rao M (2015) Performance Analysis of DI Diesel Engine Fuelled with Diesel along with Nano Additives. International Journal of Engineering Trends and Technology (IJETT) 24:107-110

Sabet Sarvestany N, Farzad A, Ebrahimnia-Bajestan E, Mir M (2014) Effects of Magnetic Nanofluid Fuel Combustion on the Performance and Emission Characteristics. Journal of Dispersion Science and Technology 35:17451750 doi:10.1080/01932691.2013.874296 
Sadhik Basha J, Anand RB (2012) Effects of nanoparticle additive in the water-diesel emulsion fuel on the performance, emission and combustion characteristics of a diesel engine. International Journal of Vehicle Design 59:164-181 doi:10.1504/IJVD.2012.048692

Sadhik Basha J, Anand RB (2013) The influence of nano additive blended biodiesel fuels on the working characteristics of a diesel engine. Journal of the Brazilian Society of Mechanical Sciences and Engineering 35:257-264 doi:10.1007/s40430-013-0023-0

Sajith V, Sobhan CB, Peterson GP (2010) Experimental Investigations on the Effects of Cerium Oxide Nanoparticle Fuel Additives on Biodiesel. Advances in Mechanical Engineering 2:581407 doi:10.1155/2010/581407

Salehian A, Shirneshan A (2020) The Effect of Cordierite-Platinum SCR Catalyst on the NOx Removal Efficiency in an Engine Fueled with Diesel-Ethanol-Biodiesel Blends. Catalysis Letters 150:2236-2253 doi:10.1007/s10562-020-03138-7

Şanli BG, Uludamar E (2019) Energy and exergy analysis of a diesel engine fuelled with diesel and biodiesel fuels at various engine speeds. Energy Sources, Part A: Recovery, Utilization, and Environmental Effects:1-15 doi:10.1080/15567036.2019.1635229

Shaafi T, Velraj R (2015) Influence of alumina nanoparticles, ethanol and isopropanol blend as additive with dieselsoybean biodiesel blend fuel: Combustion, engine performance and emissions. Renewable Energy 80:655663 doi:https://doi.org/10.1016/j.renene.2015.02.042

Shirneshan A, Almassi M, Ghobadian B, Borghei AM, Najafi G (2016a) Response surface methodology (RSM) based optimization of biodiesel-diesel blends and investigation of their effects on diesel engine operating conditions and emission characteristics. Environmental Engineering and Management Journal 15:2771-2780

Shirneshan A, Samani BH, Ghobadian B (2016b) Optimization of biodiesel percentage in fuel mixture and engine operating conditions for diesel engine performance and emission characteristics by Artificial Bees Colony Algorithm. Fuel 184:518-526 doi:http://dx.doi.org/10.1016/j.fuel.2016.06.117

Shirneshan AR, Almassi M, Ghobadian B, Najafi GH (2014) Investigating the effects of biodiesel from waste cooking oil and engine operating conditions on the diesel engine performance by response surface methodology. Iranian Journal of Science and Technology - Transactions of Mechanical Engineering 38:289-301

Singh TS, Verma TN (2019) Biodiesel production from Momordica Charantia (L.): Extraction and engine characteristics. Energy 189:116198 doi:https://doi.org/10.1016/j.energy.2019.116198

Sivakumar M, Shanmuga Sundaram N, Ramesh kumar R, Syed Thasthagir MH (2018) Effect of aluminium oxide nanoparticles blended pongamia methyl ester on performance, combustion and emission characteristics of diesel engine. Renewable Energy 116:518-526 doi:https://doi.org/10.1016/j.renene.2017.10.002

Soudagar MEM, Nik-Ghazali N-N, Abul Kalam M, Badruddin IA, Banapurmath NR, Akram N (2018) The effect of nano-additives in diesel-biodiesel fuel blends: A comprehensive review on stability, engine performance and emission characteristics. Energy Conversion and Management 178:146-177 doi:https://doi.org/10.1016/j.enconman.2018.10.019

Soukht Saraee H, Taghavifar H, Jafarmadar S (2017) Experimental and numerical consideration of the effect of CeO2 nanoparticles on diesel engine performance and exhaust emission with the aid of artificial neural network. Applied Thermal Engineering 113:663-672 doi:https://doi.org/10.1016/j.applthermaleng.2016.11.044

Srinidhi C (2017) A Diesel Engine Performance Investigation fueled with Nickel oxide nano fuel-methyl ester. International Journal of Renewable Energy Research-IJRER 7:676-681

Srinidhi C, Madhusudhan A, Channapattana SV (2019) Effect of NiO nanoparticles on performance and emission characteristics at various injection timings using biodiesel-diesel blends. Fuel 235:185-193 doi:https://doi.org/10.1016/j.fuel.2018.07.067 
Takeda M, Onishi T, Nakakubo S, Fujimoto S (2009) Physical Properties of Iron-Oxide Scales on Si-Containing Steels at High Temperature. MATERIALS TRANSACTIONS 50:2242-2246 doi:10.2320/matertrans.M2009097

Tikhomirov K, Kröcher O, Elsener M, Widmer M, Wokaun A (2006) Manganese based materials for diesel exhaust SO2 traps. Applied Catalysis B: Environmental 67:160-167 doi:https://doi.org/10.1016/j.apcatb.2006.03.025

Vairamuthu G, Sundarapandian S, Kailasanathan C, Thangagiri B (2016) Experimental investigation on the effects of cerium oxide nanoparticle on Calophyllum inophyllum (Punnai) biodiesel blended with diesel fuel in DI diesel engine modified by nozzle geometry. Journal of the Energy Institute 89:668-682 doi:https://doi.org/10.1016/j.joei.2015.05.005

Venu H, Madhavan V (2016a) Effect of Al2O3 nanoparticles in biodiesel-diesel-ethanol blends at various injection strategies: Performance, combustion and emission characteristics. Fuel 186:176-189 doi:https://doi.org/10.1016/j.fuel.2016.08.046

Venu H, Madhavan V (2016b) Effect of nano additives (titanium and zirconium oxides) and diethyl ether on biodieselethanol fuelled CI engine. Journal of Mechanical Science and Technology 30:2361-2368 doi:10.1007/s12206-016-0446-5

Venu H, Subramani L, Raju VD (2019) Emission reduction in a DI diesel engine using exhaust gas recirculation (EGR) of palm biodiesel blended with TiO2 nano additives. Renewable Energy 140:245-263 doi:https://doi.org/10.1016/j.renene.2019.03.078

Yu W, Xie H (2012) A Review on Nanofluids: Preparation, Stability Mechanisms, and Applications. Journal of Nanomaterials 2012:17 doi:10.1155/2012/435873

\section{Appendix 1}

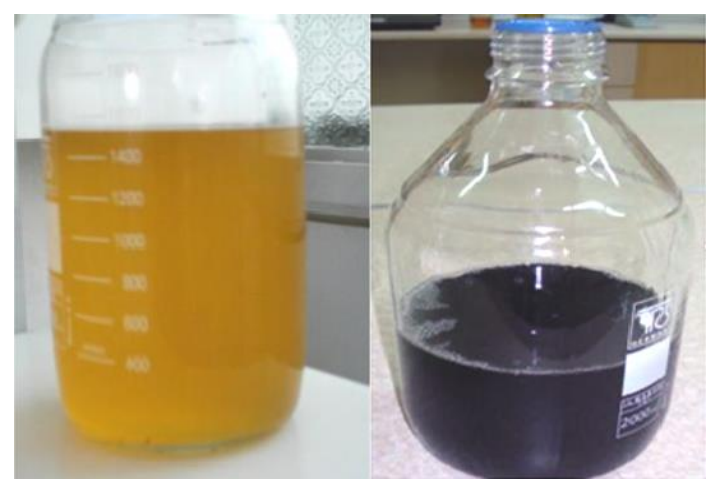

Figure A1: $\mathrm{Al}_{2} \mathrm{O}_{3}$ (left) and $\mathrm{Fe}_{3} \mathrm{O}_{4}$ (right) nanoparticle-diesel fuel blends

Table A1: Properties of nanoparticle-diesel fuel blends

\begin{tabular}{|c|c|c|c|c|c|c|c|c|c|c|c|}
\hline Property & unit & Range & Method & 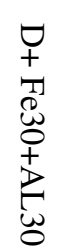 & $\begin{array}{l}\nabla \\
+ \\
\mathbb{1} \\
\mathbb{8} \\
8\end{array}$ & $\begin{array}{l}\square \\
+ \\
7 \\
8 \\
8\end{array}$ & $\begin{array}{l}\square \\
+ \\
+1 \\
0 \\
\stackrel{0}{0}\end{array}$ & $\begin{array}{l}\nabla \\
+ \\
\geq \\
\varnothing \\
8\end{array}$ & $\begin{array}{l}\nabla \\
+ \\
\geq \\
8 \\
8\end{array}$ & 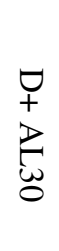 & $\begin{array}{l}\vec{\varpi} \\
0 \\
0 \\
\mathbb{0} \\
\overrightarrow{0}\end{array}$ \\
\hline
\end{tabular}




\begin{tabular}{|c|c|c|c|c|c|c|c|c|c|c|c|}
\hline Flash point & ${ }^{\circ} \mathrm{C}$ & $52<$ & D93 & 64 & 67 & 64 & 63 & 69 & 67 & 66 & 58 \\
\hline Cloud point & ${ }^{\circ} \mathrm{C}$ & - & D2500 & -4 & -5 & -4 & -4 & -6 & -6 & -5 & -3 \\
\hline $\begin{array}{c}\text { Kinematic } \\
\text { viscosity } \\
\left(40^{\circ} \mathrm{C}\right)\end{array}$ & $\mathrm{Mm}^{2} / \mathrm{s}$ & $1.9-4.1$ & D445 & 3.6 & 3.8 & 3.7 & 3.6 & 3.9 & 3.8 & 3.6 & 3.5 \\
\hline Density & $\mathrm{g} / \mathrm{cm}^{3}$ & - & D4052 & 0.820 & 0.823 & 0.821 & 0.817 & 0.827 & 0.825 & 0.824 & 0.816 \\
\hline $\begin{array}{c}\text { Heating } \\
\text { value }\end{array}$ & $\mathrm{kJ} / \mathrm{kg}$ & - & D 3338 & 43453 & 43729 & 43657 & 43442 & 43685 & 43502 & 43365 & 42929 \\
\hline $\begin{array}{l}\text { Cetane } \\
\text { number }\end{array}$ & - & - & D613 & 55.2 & 56.4 & 55.9 & 55.3 & 55.6 & 55.3 & 54.7 & 51 \\
\hline
\end{tabular}


Figures

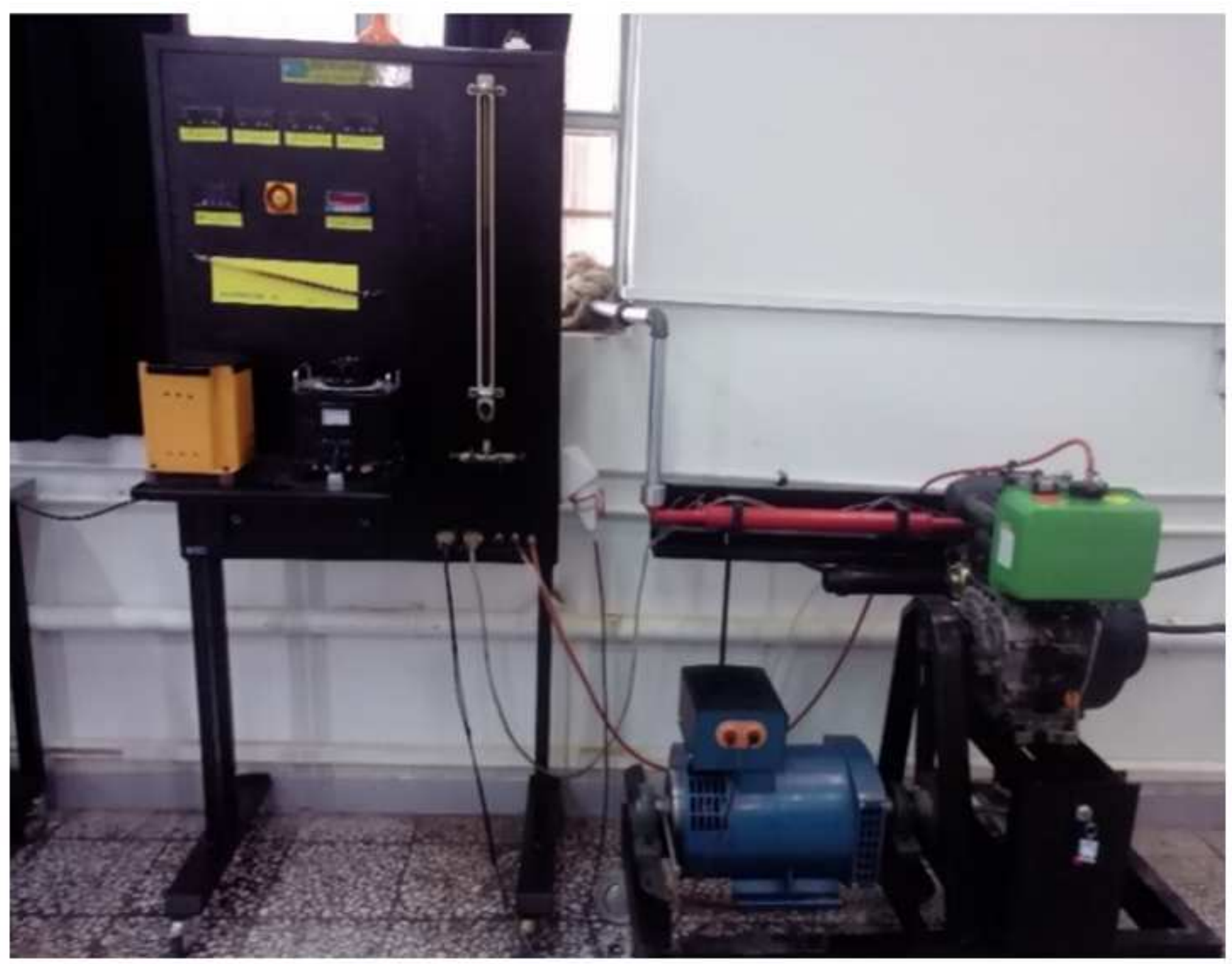

Figure 1

The engine test set-up 

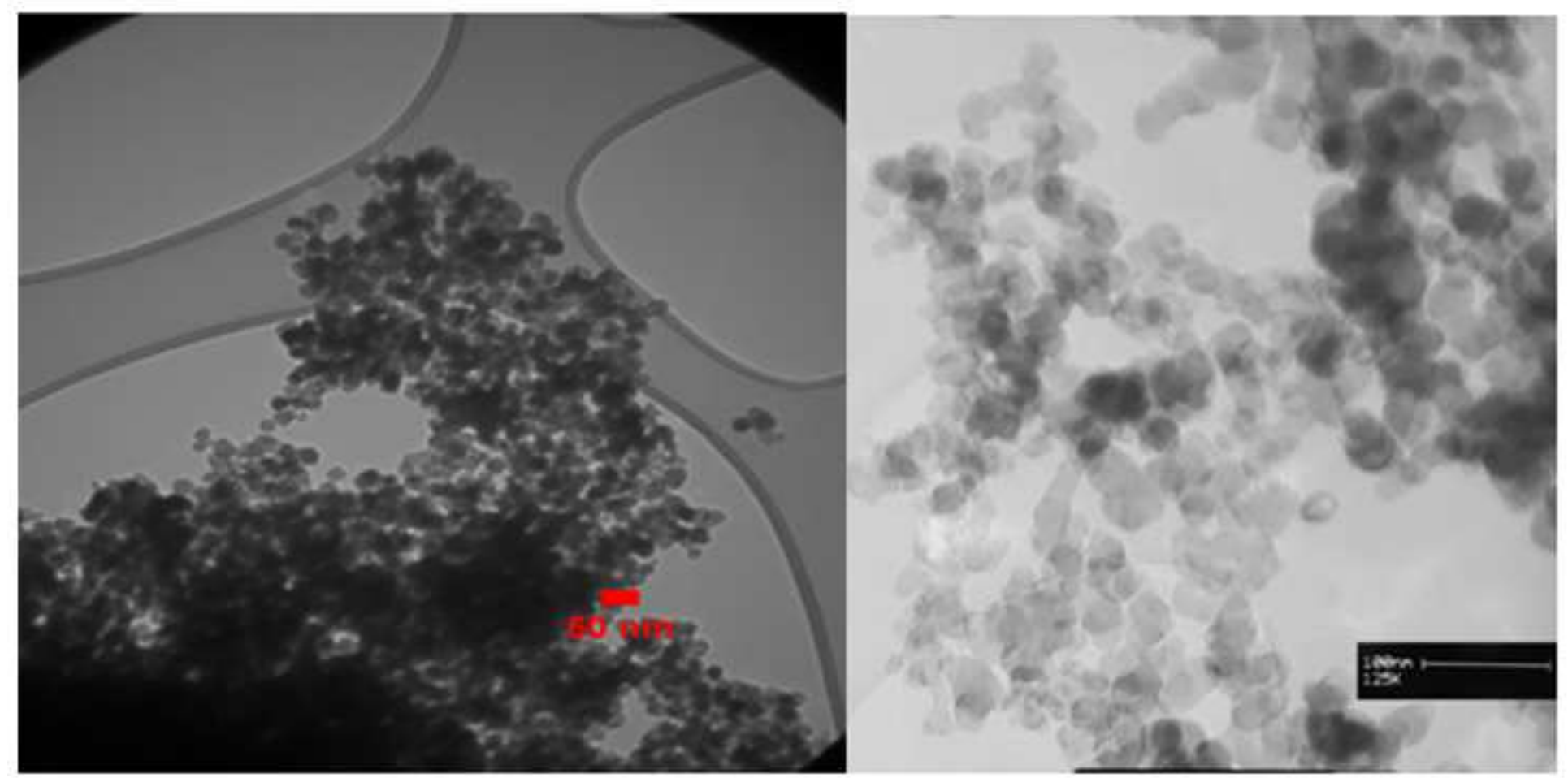

Figure 2

TEM and SEM analysis of Al2O3 nanoparticles

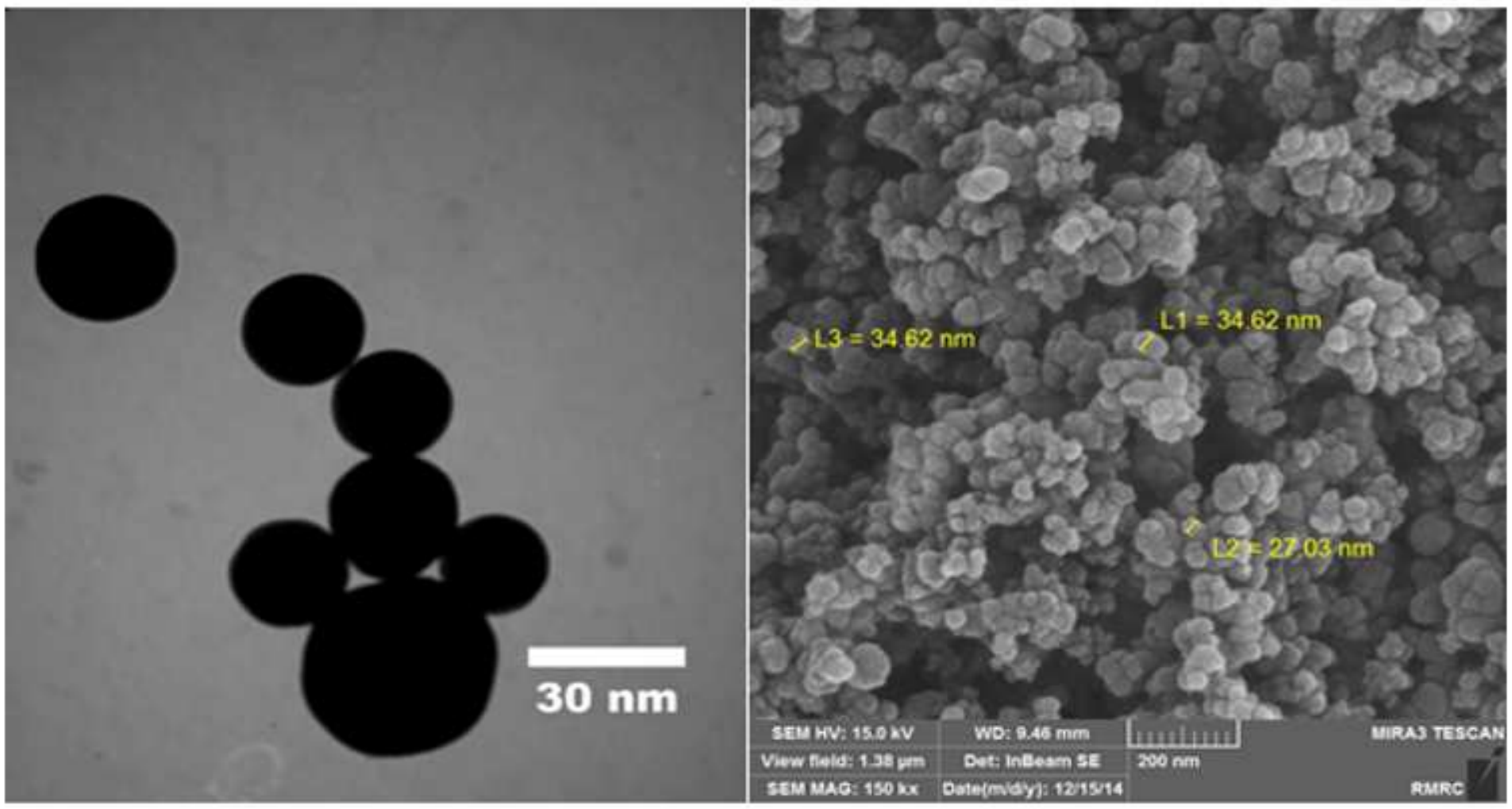

Figure 3

TEM and SEM analysis of Fe2O3 nanoparticles 


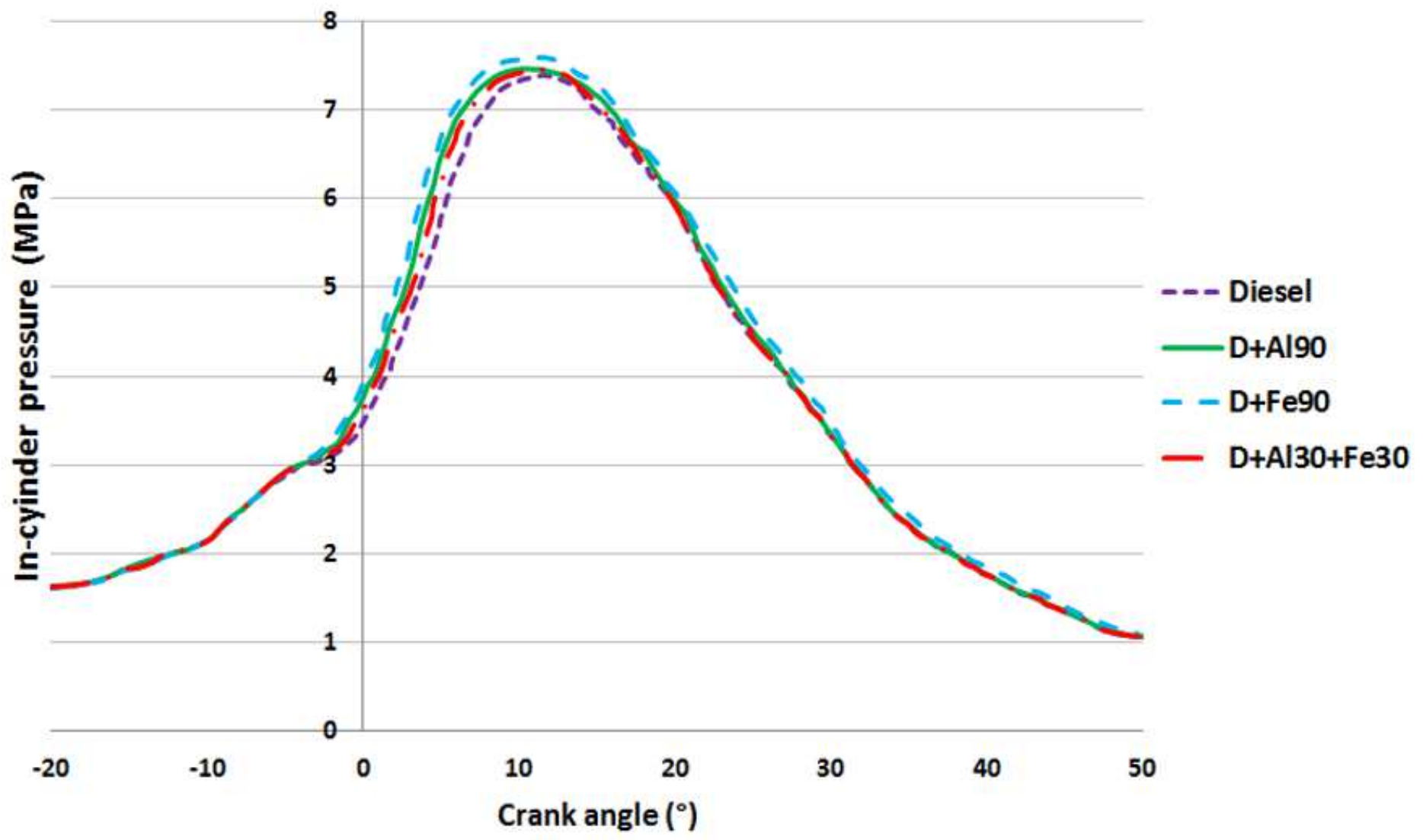

Figure 4

In-cylinder pressure variations versus crank angle at $50 \%$ engine load 


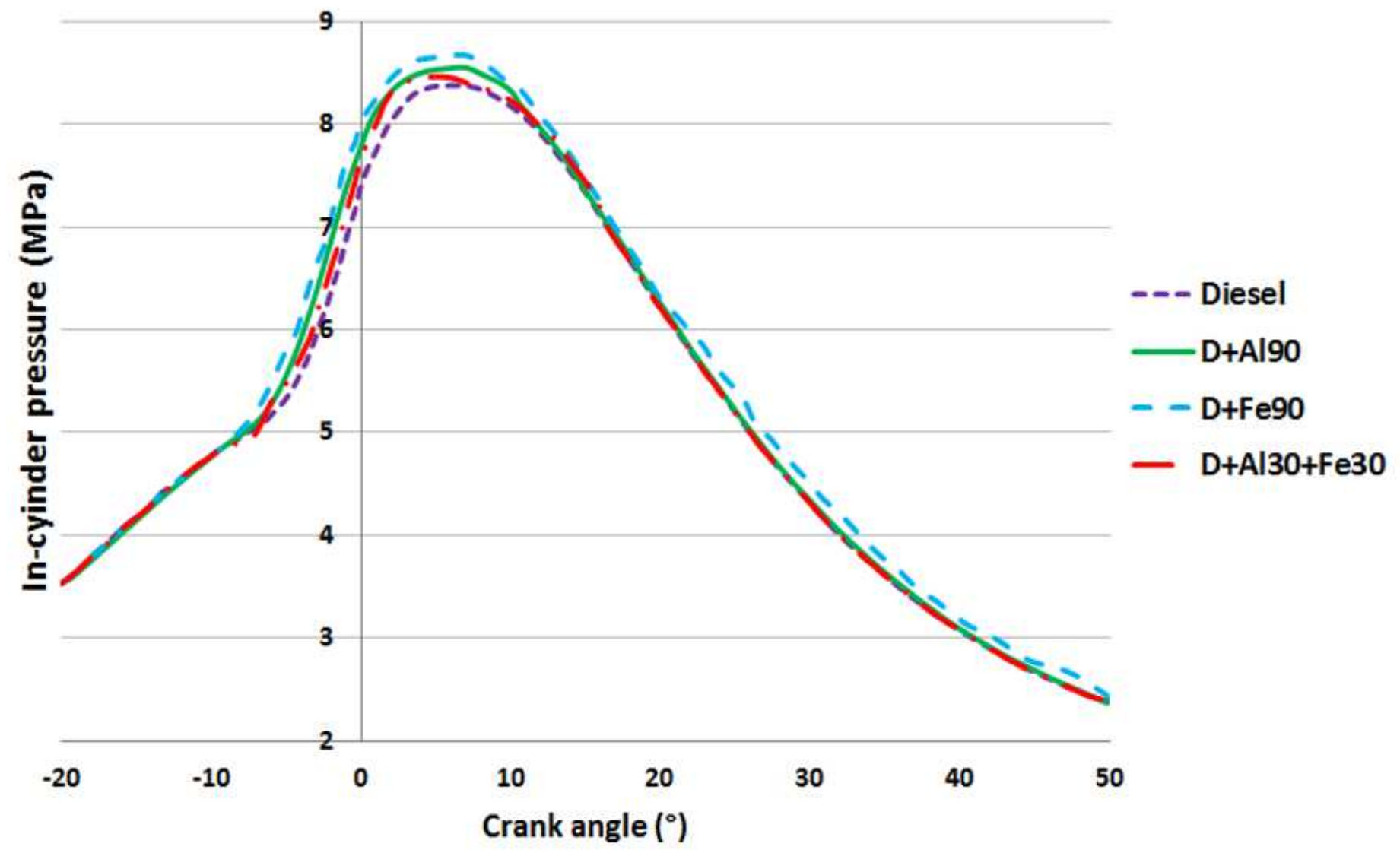

Figure 5

In-cylinder pressure variations versus crank angle at full engine load

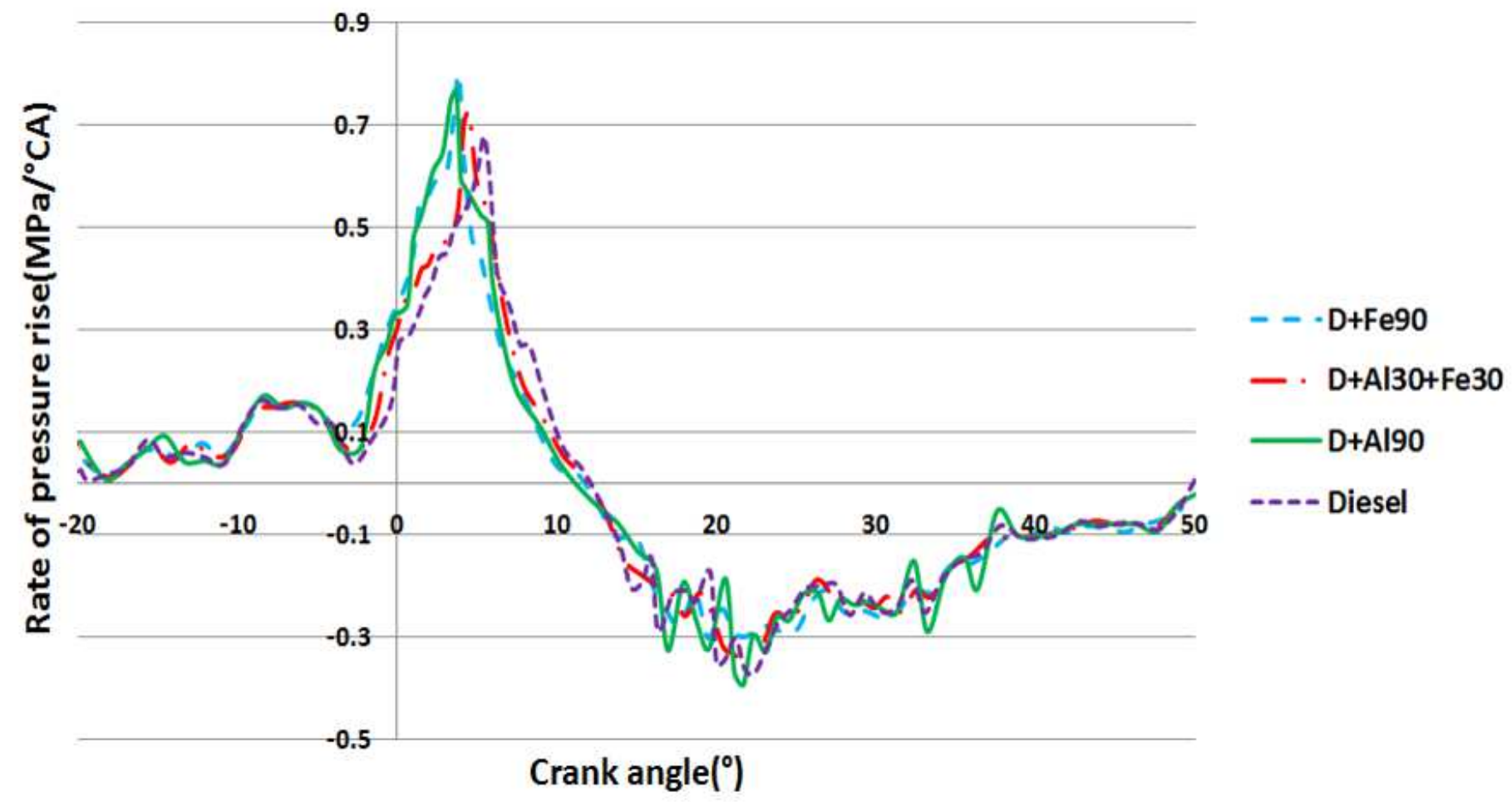


Figure 6

Variations of the rate of pressure rise against crank angle at 50\% engine load

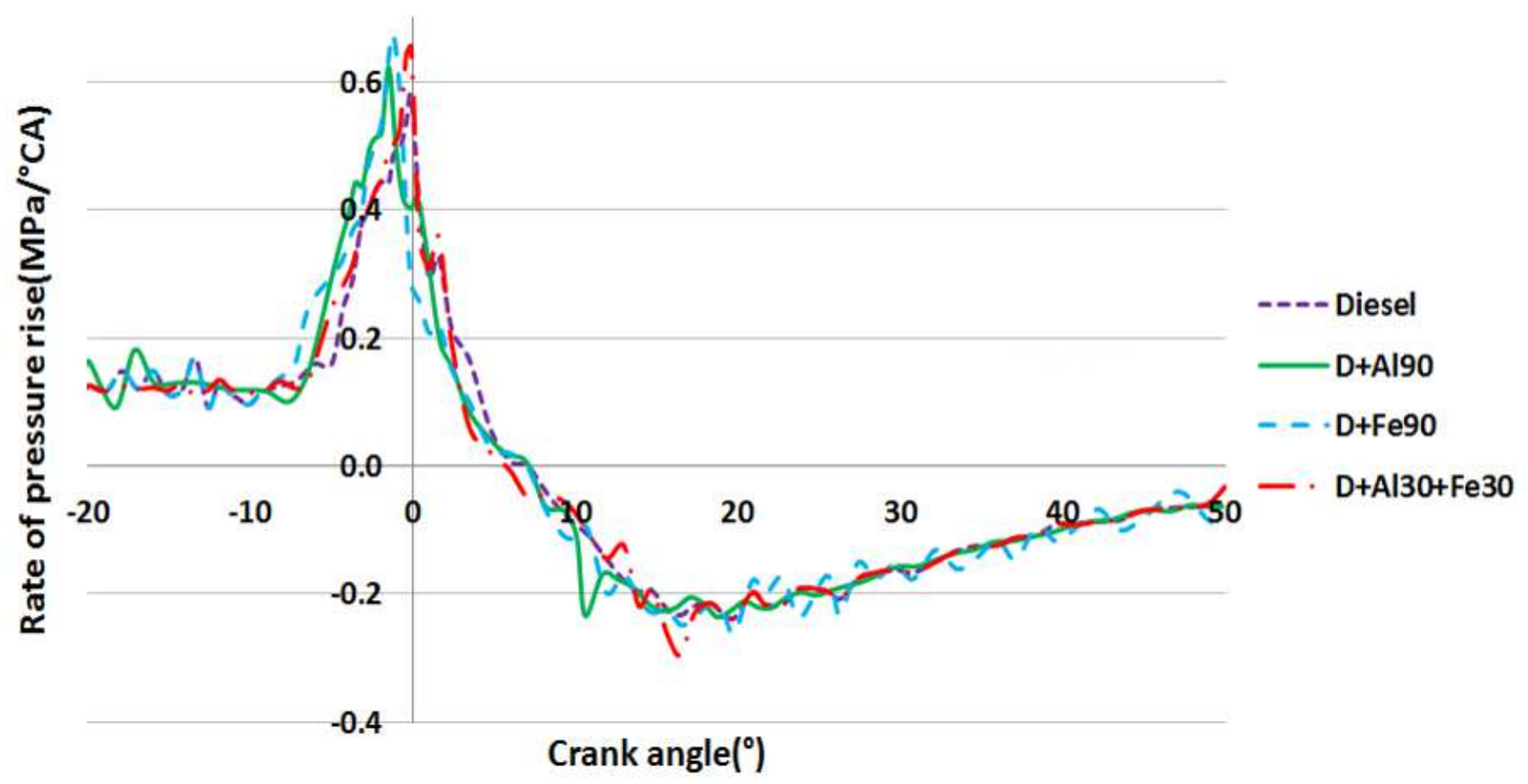

Figure 7

Variations of the rate of pressure rise against crank angle at full engine load 


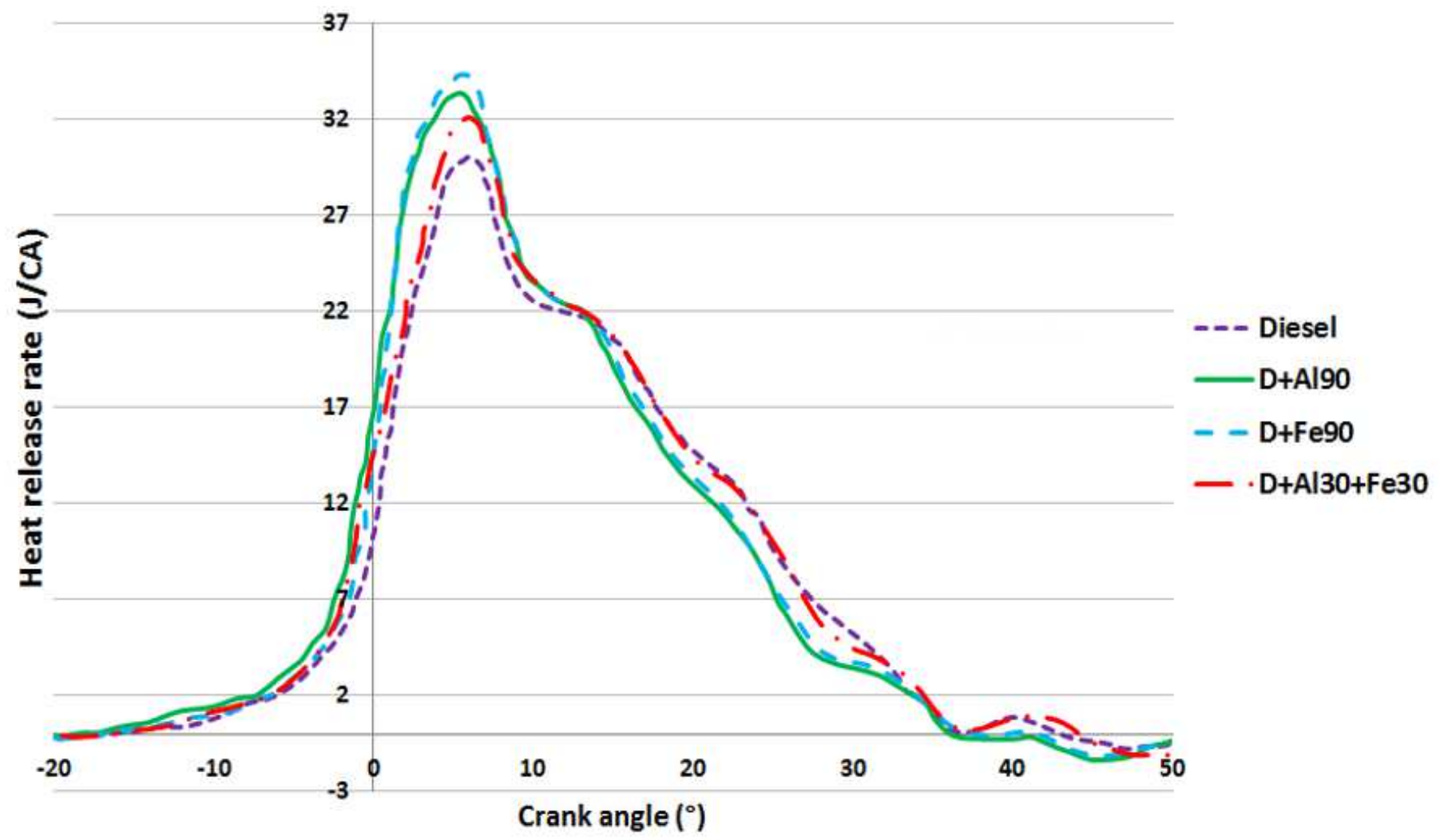

Figure 8

Variations of the HRR versus crank angle at $50 \%$ engine load

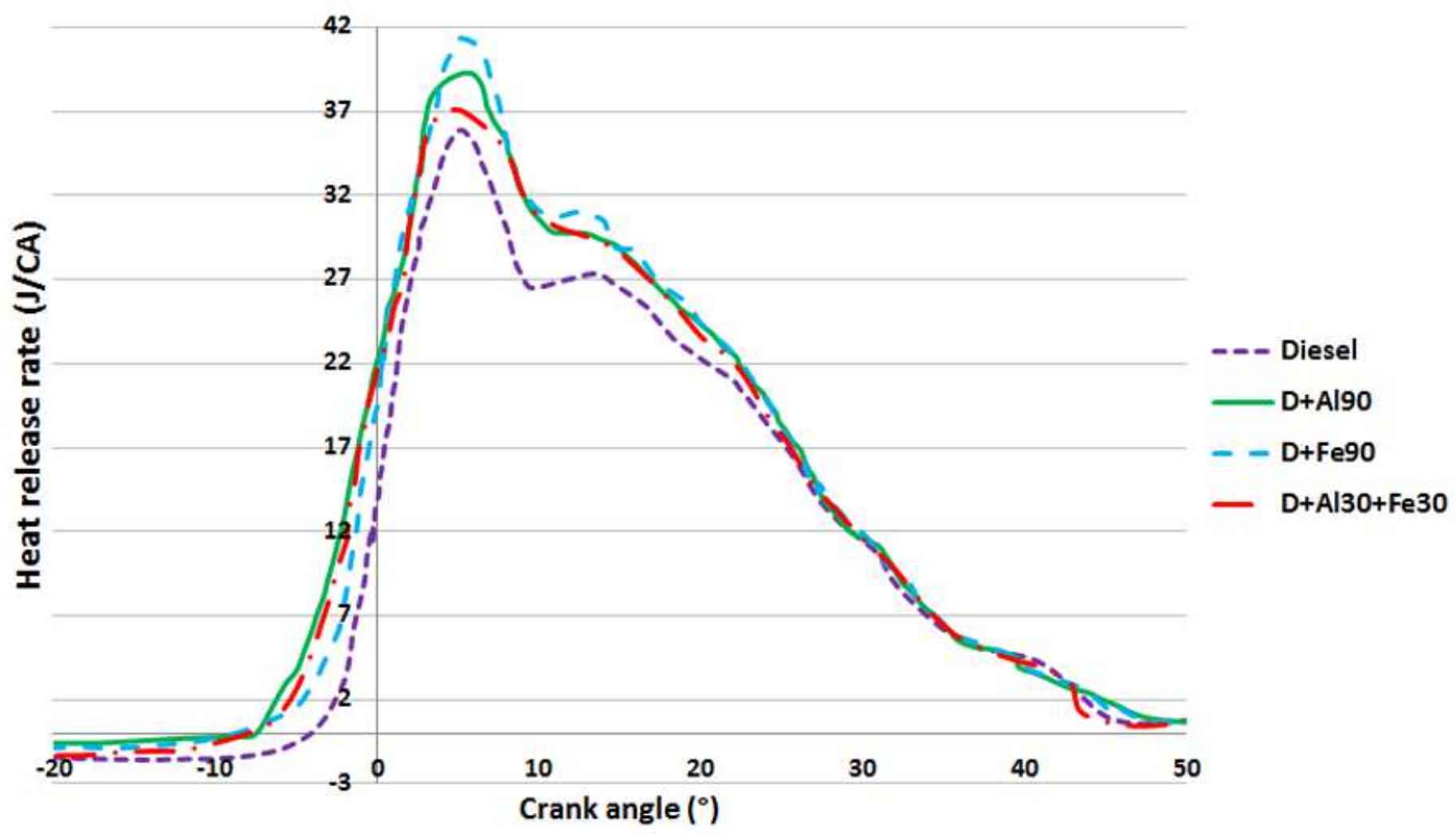


Figure 9

Variations of the HRR versus crank angle at full engine load

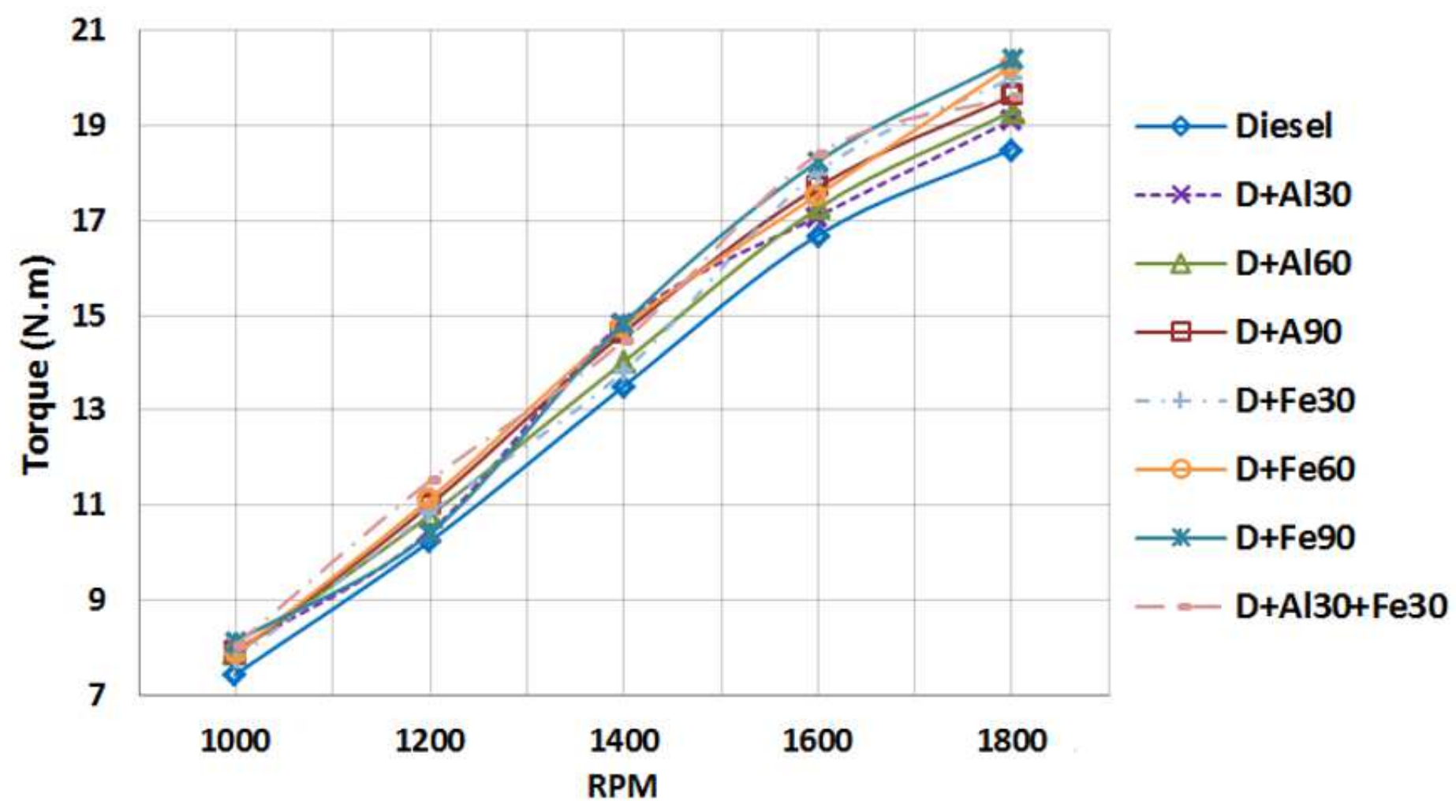

Figure 10

Brake torque values versus rotational speed for different nanoparticle-diesel fuel blends at full engine load 


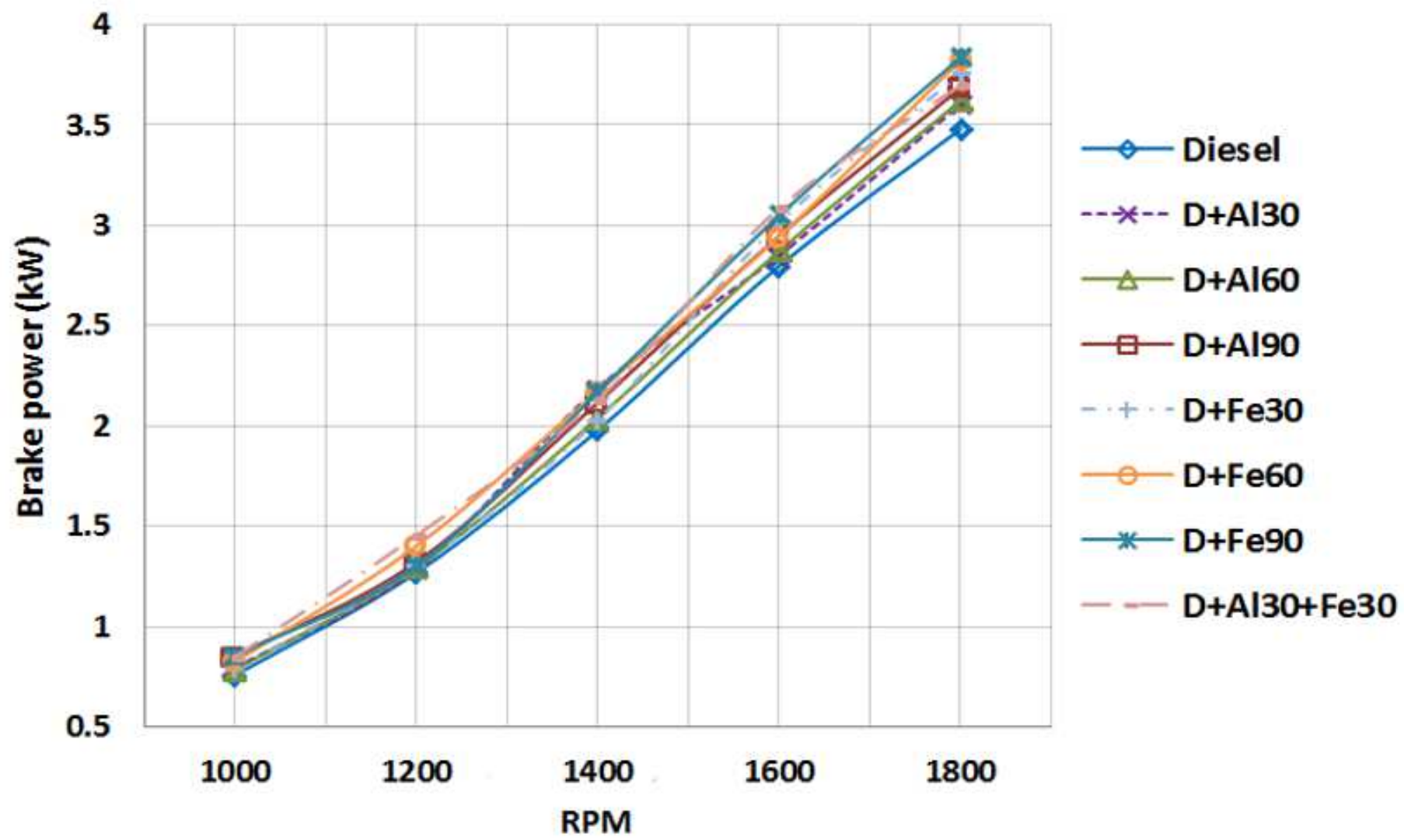

Figure 11

Brake power values versus rotational speed for different nanoparticle-diesel fuel blends at full engine load 


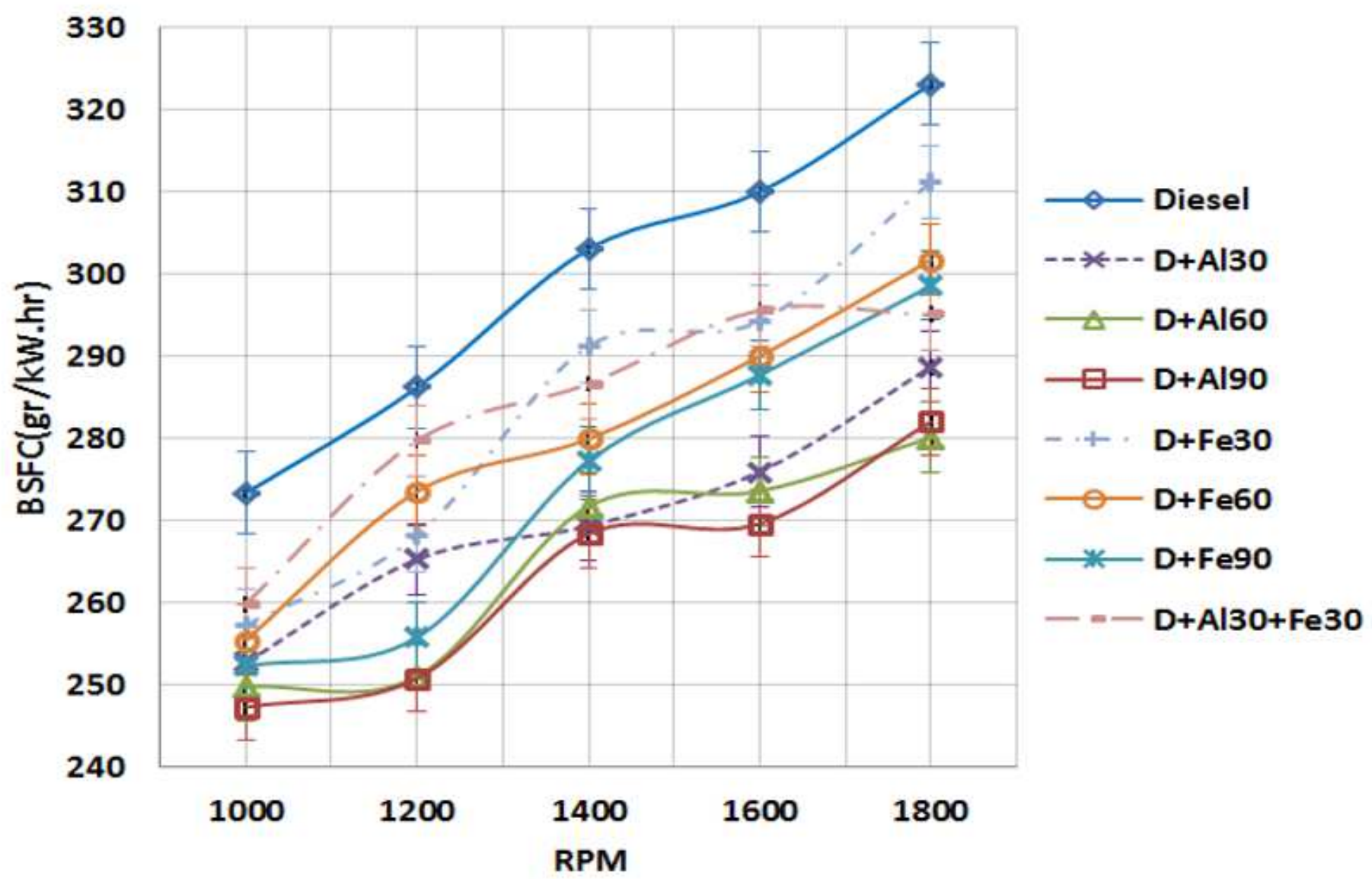

Figure 12

BSFC values versus rotational speed for various fuel blends at $50 \%$ engine load 


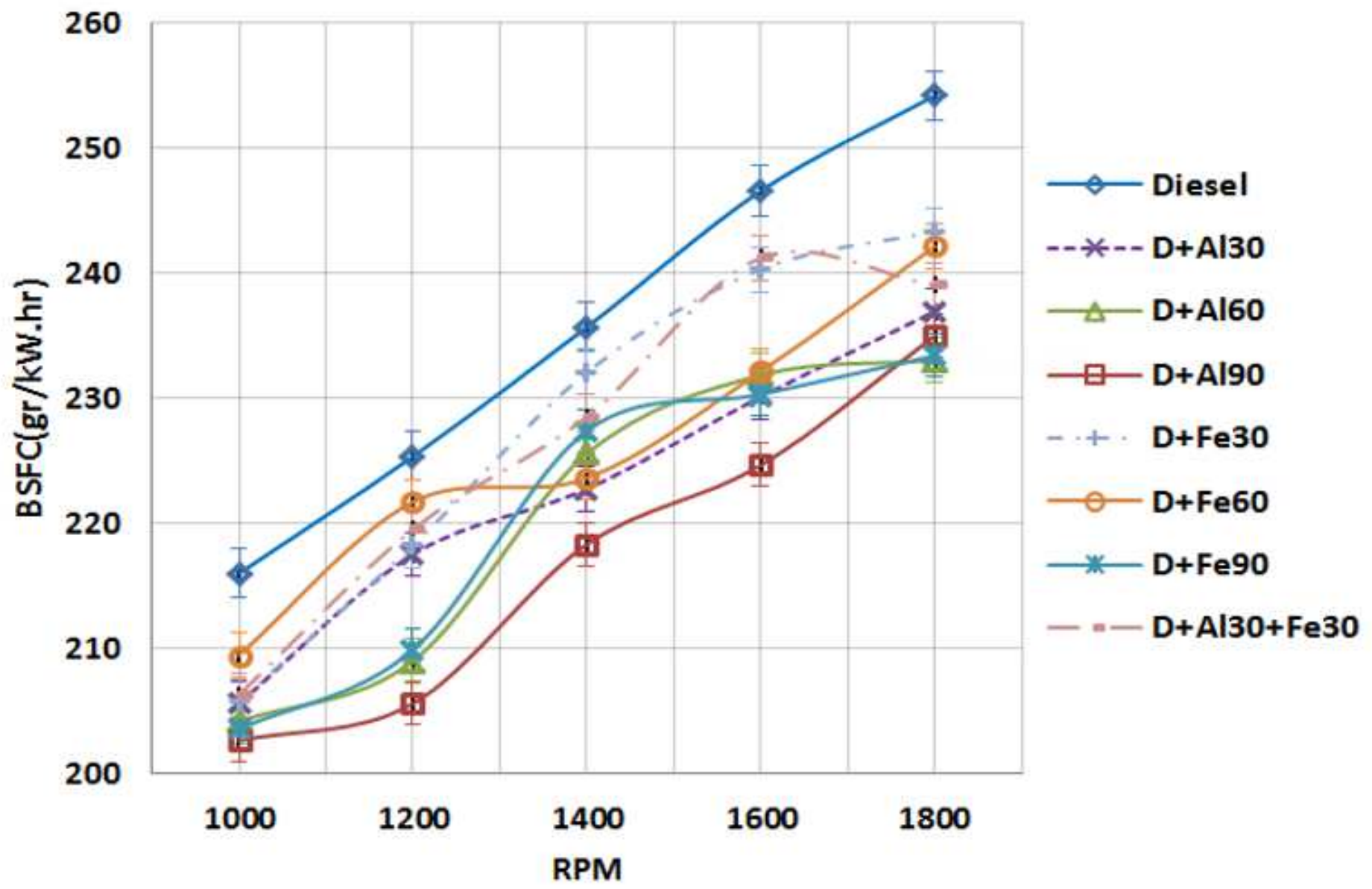

Figure 13

BSFC values versus rotational speed for various fuel blends at full engine load 


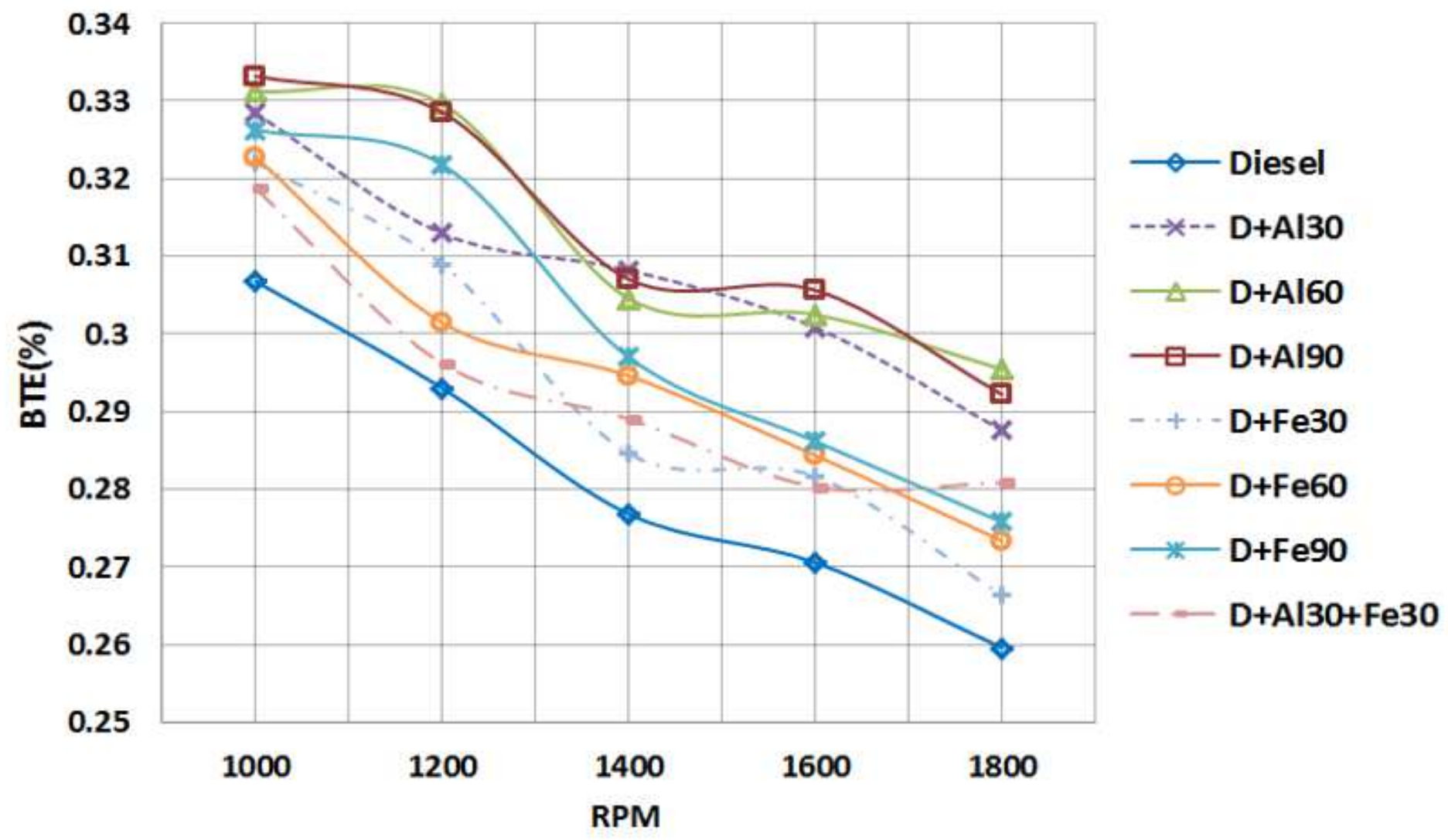

Figure 14

BTE values versus rotational speed for different nanoparticle-diesel fuel blends at $50 \%$ engine load

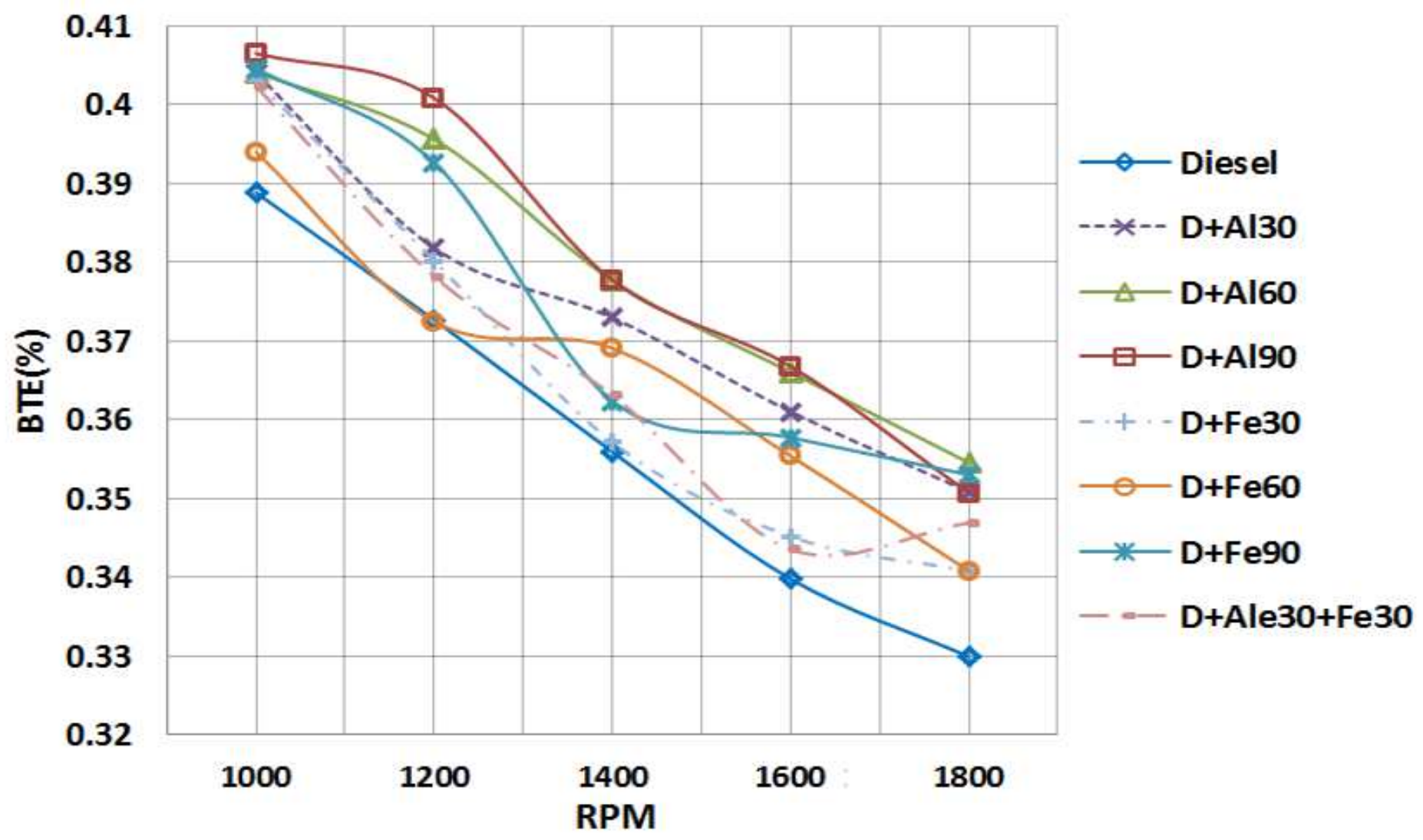


Figure 15

BTE values versus rotational speed for different nanoparticle-diesel fuel blends at full engine load

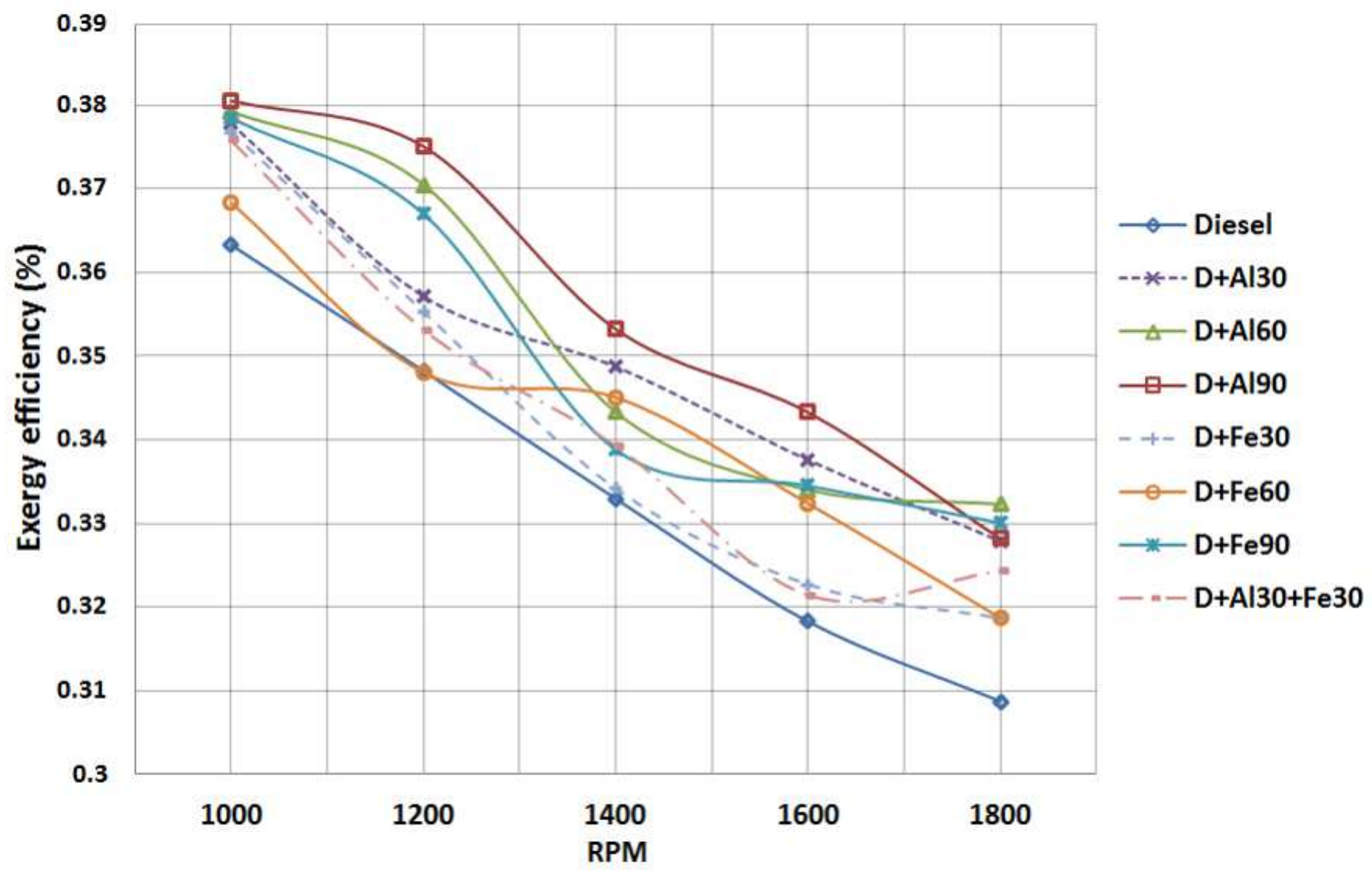

Figure 16

Exergy efficiency values versus rotational speed for different nanoparticle-diesel fuel blends at full engine load 


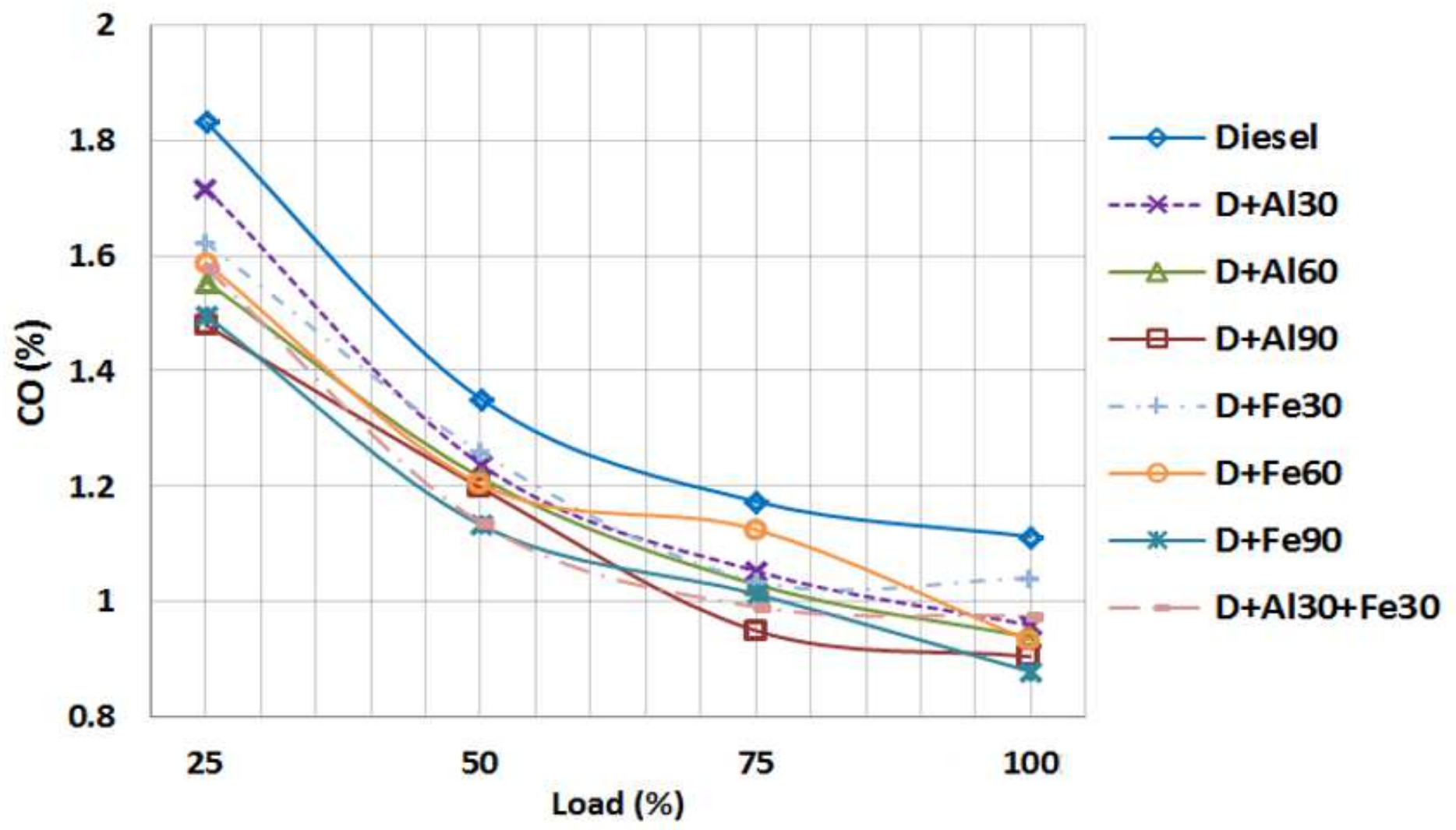

Figure 17

Variations of the $\mathrm{CO}$ emission against engine load for different nanoparticle-diesel fuel blends

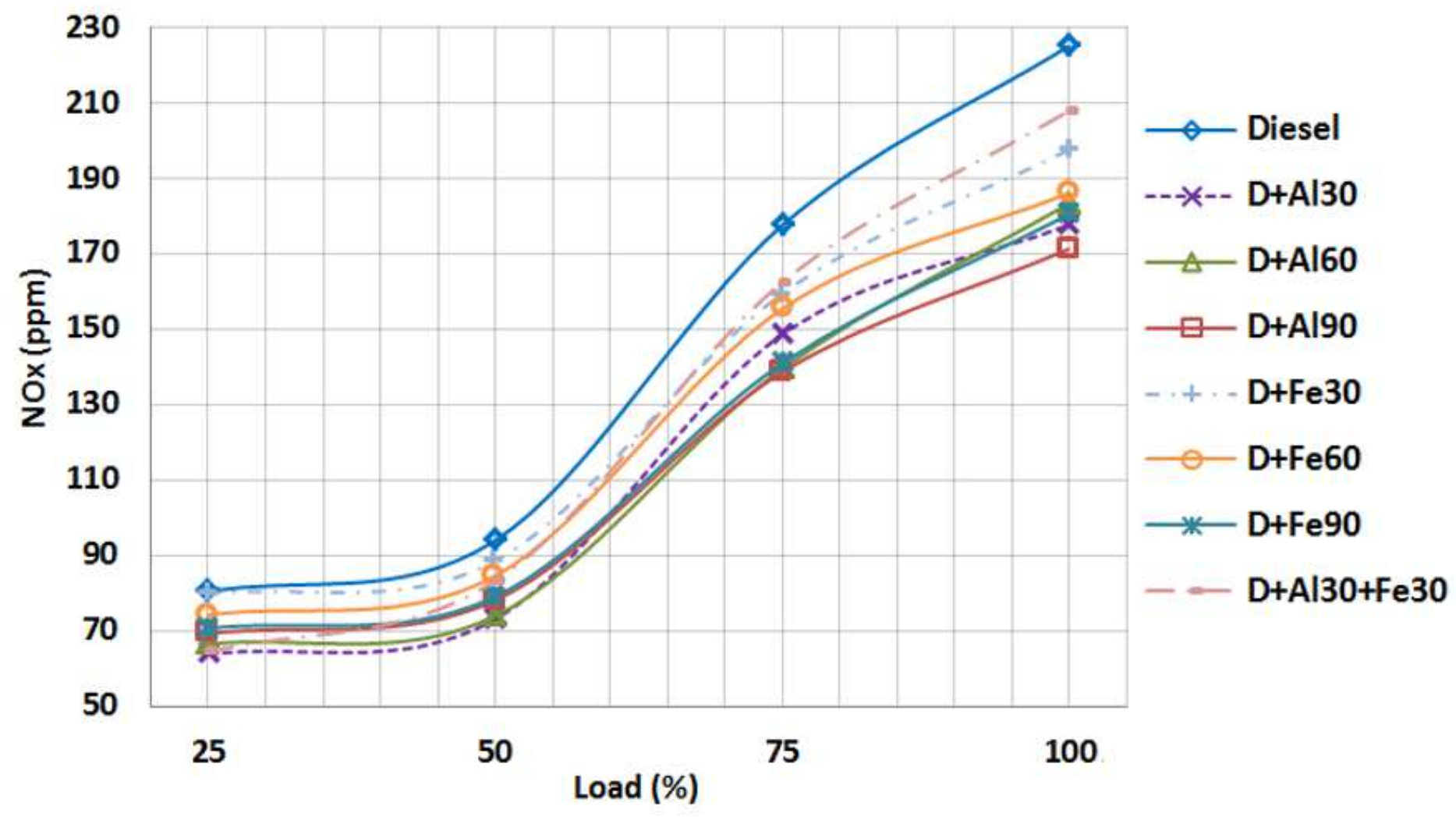


Figure 18

Variations of the NOx emission versus engine load for different nanoparticle-diesel fuel blends

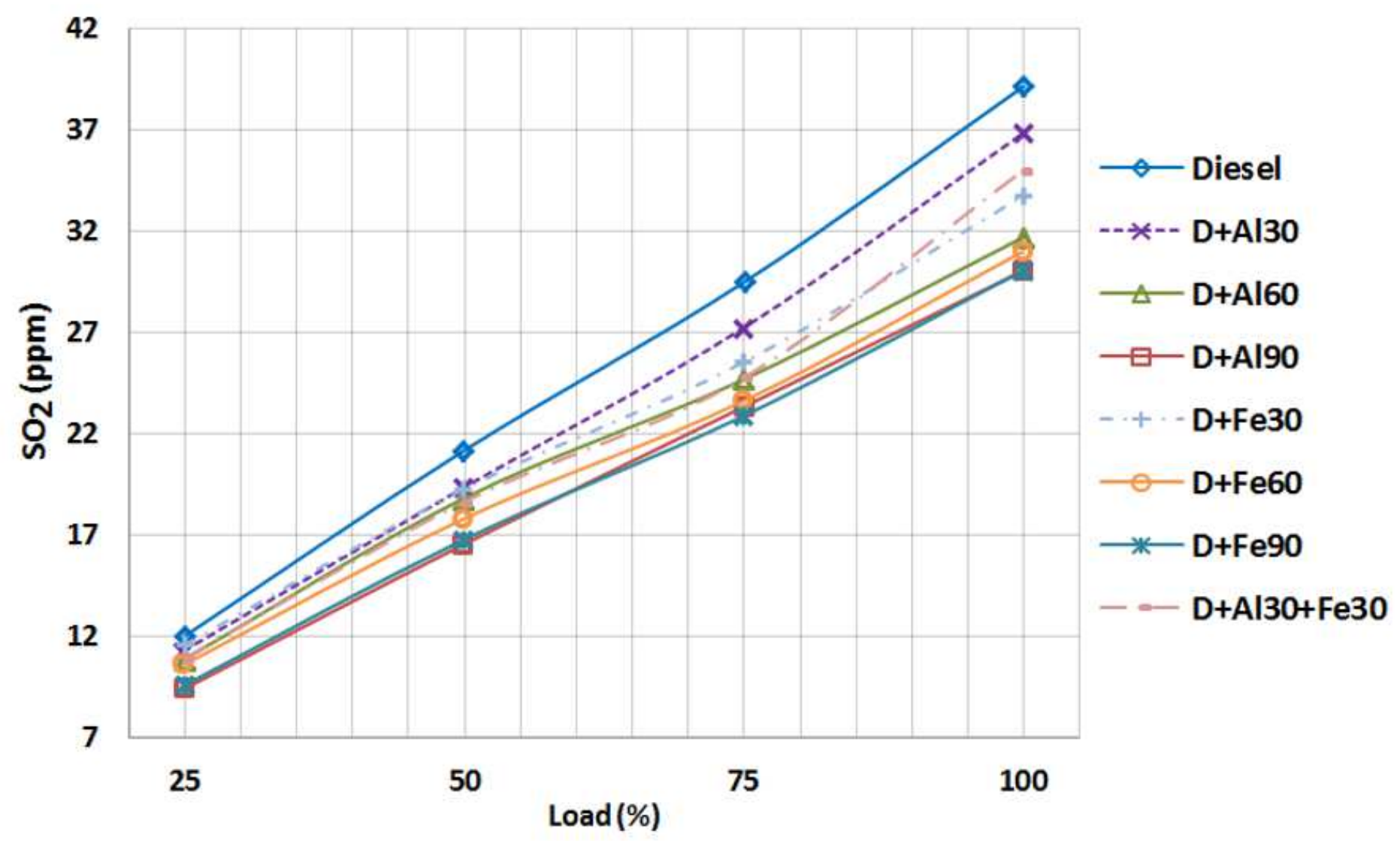

Figure 19

Variations of the SO2 emission against engine load for different nanoparticle-diesel fuel blends

\section{Supplementary Files}

This is a list of supplementary files associated with this preprint. Click to download.

- Slide1.tif

- Appendix1.docx 